UNITED STATES DEPARTMENT OF THE INTERIOR

Harold L. Ickes, Secretary

GEOLOGICAL SURVEY

W. C. Mendenhall, Director

Water-Supply Paper 778

\title{
GEOLOGY AND GROUND-WATER RESOURCES OF WEBB COUNTY, TEXAS
}

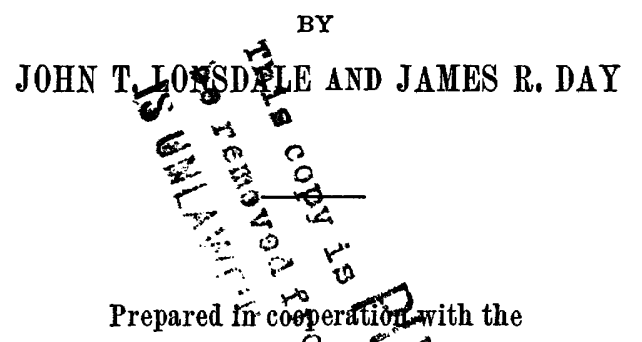

WNGINEERING EXPERIMENT, STTIOT THE AGRICULTURAL

$\triangle$ ND MECHANICAL COLEEGE,OF TEXAS and the TEXAS

BOARD OF WATERENGTAERS

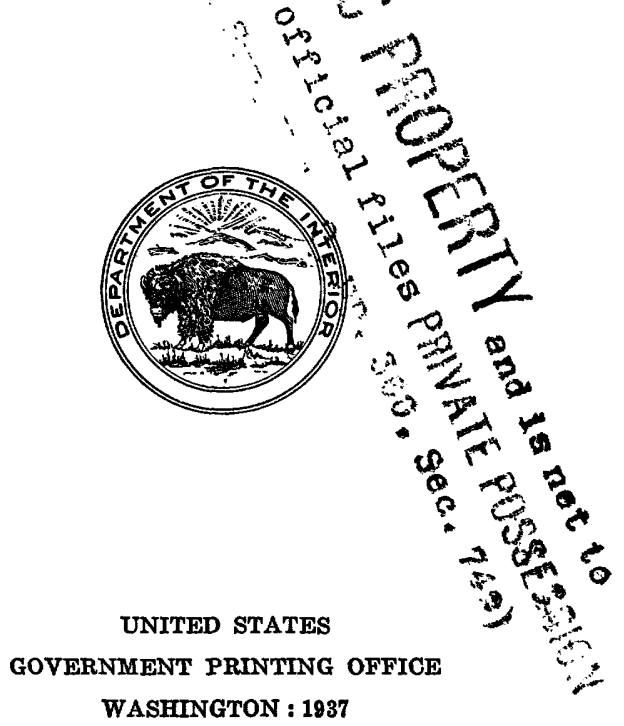

For sale by the Superintendent of Documents, Washington, D. C. - - - - - - Price 30 cents 



\section{CONTENTS}

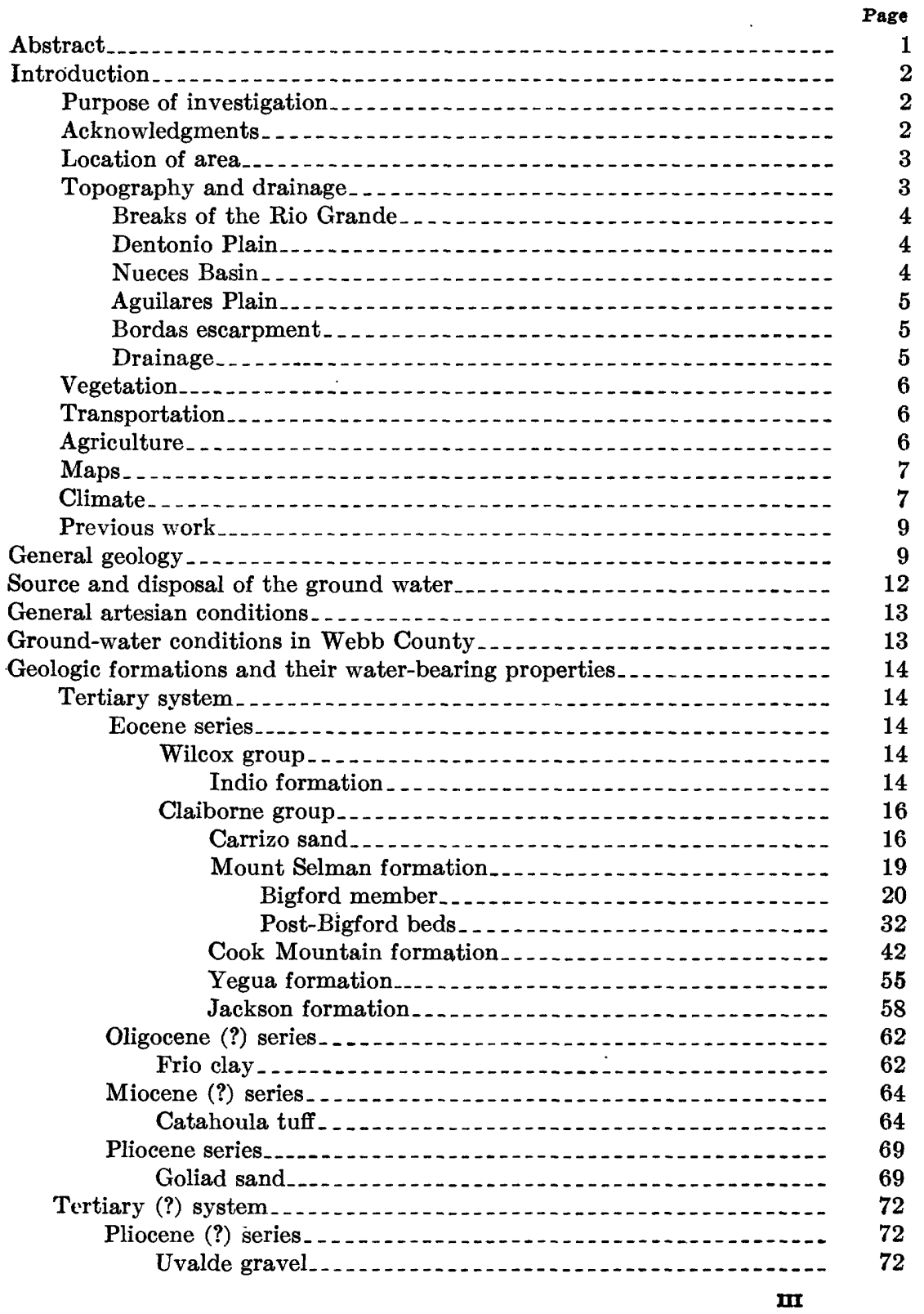


Geologic formations and their water-bearing properties-Continued.

Quaternary system

Recent series.

Alluvium

Mineral resources

Coal

Gravel

Oil and gas

Summary of conclusions

Index

\section{ILLUSTRATIONS}

Prate 1. Areal geologic and hydrologic map and cross sections of Webb

County, Tex........ In pocket

2. $A$, Breaks of the Rio Grande near Palafox; $B$, Breaks of the Rio Grande near Palafox; alluvial flat shown in top of view; $C$, Dentonio Plain near Galvan ranch........................

3. $A$, Bordas escarpment near Mirando City; $B$, Beds of the Jackson formation upturned and faulted 1.3 miles south of Corpus Christi highway on Retama Creek

4. A, Contact of Indio formation and Carrizo sand at mouth of Chupadero Creek; $B$, Alternating shale and sandstone strata of Indio formation on Borrego Creek . . . . . . .

5. $A$, Indurated sandstone of Carrizo formation at Rocktown, southeast of Chupadero ranch; $B$, Carrizo sand on Mexican side of Rio Grande south of Chupadero ranch . .............

6. $A$, Juan Rey Spring, Chupadero ranch; $B$, Open prairie country characteristic of outcrop of Carrizo sand, Chupadero ranch..-

7. Correlation of the Carrizo sand in typical wells in northwestern Webb County, showing depth below sea level..............

8. $A$, Bigford strata near mouth of San Cirile Creek; $B$, Bigford strata half a mile above mouth of San Cirile Creek ...........

9. A, Cuesta formed by hard sandstone bed in post-Bigford part of Mount Selman formation, half a mile south of Pilotes ranch; $B$, Exposures of Santo Tomas and related coal beds 4 miles southeast of Palafox.

10. $A$, Fossiliferous shale and sandstone near base of the Cook Mountain formation on the Laredo-Dolores road at the west fork of Sambarieto Creek; $B$, Sandstone and shale in top of middle part of Cook Mountain formation 2.9 miles southeast of Laredo post office.

11. Correlation of Mount Selman, Cook Mountain, Yegua, and Jackson formations and water sands in typical wells in northern Webb County.

12. $A$, Oyster bed and clay near base of Yegua formation 7.5 miles east of Laredo post office; $B$, Typical Yegua clay 8.7 miles east of Laredo post office. 
Fiadre 1. Map of Texas showing location of Webb County

2. Composite columnar section of Bigford member of Mount Selman formation showing fossil horizons and coal beds....

3. Composite columnar section of post-Bigford part of Mount Selman formation showing fossil horizons and coal beds.....-

4. Composite columnar section of Cook Mountain formation showing predominance of sand and sandstone members.......

5. Sketch map showing location of measured sections of Cook Mountain formation

6. Composite columnar section of Yegua formation showing predominance of clay

\section{INSERT}

Rock formations in Webb County, Tex., and their water-bearing properties. 



\title{
GEOLOGY AND GROUND-WATER RESOURCES OF WEBB COUNTY, TEXAS
}

\author{
By John T. Lonsdale and James R. Day
}

\begin{abstract}
\end{abstract}
Webb County is in southwestern Texas and is a part of the Winter Garden district. The purpose of the investigation here recorded was to determine the source, quantity, and quality of the ground water used for irrigation and other purposes in the area.

The rock formations exposed are of Tertiary and Quaternary age and dip Gulfward at a greater angle than the slope of the land surface, resulting in northsouth belts of outcropping formations. This general structure is modified by anticlines and faults, which, however, do not affect greatly the movement of ground water. In order from oldest to youngest the exposed formations are the Indio formation (850 feet thick), of Wilcox age; Carrizo sand (250 feet thick), Bigford member of the Mount Selman formation (660 feet thick), post-Bigford beds of the Mount Selman formation (1,165 feet thick), Cook Mountain formation (670 feet thick), and Yegua formation (670 feet thick), of Claiborne age; Jackson formation (1,500 feet thick) and Frio clay (250 feet thick), of Oligocene (?) age; Catahoula tuff (750 feet thick), of Miocene (?) age; Goliad sand (100 feet thick), of Pliocene age; Uvalde gravel (25 feet thick), of Pliocene (?) age; and stream deposits of Quaternary age.

The chief water-bearing formations in the area are the Carrizo sand, Cook Mountain formation, Catahoula tuff, Goliad sand, and local stream deposits. The Carrizo sand crops out in the northwestern part of the area and furnishes shallow wells in the outcrop area and deeper nonflowing wells east of the outcrop. Water from this formation is of good quality, and wells of large yield could be obtained from the formation in a considerable area. Maps accompanying the report show the outcrop of the sand and the altitude at which it will be encountered in wells.

The Cook Mountain formation contains Jarge amounts of sand and sandstone and is an important aquifer for domestic water supply and to some extent for irrigation water supply. The water is of variable quantity and quality, and some is highly mineralized. Water from this formation is used for irrigation near Encinal and Laredo. Flowing wells are obtained in low areas in northeastern Webb County, but the water is generally too highly mineralized for irrigation.

The Catahoula tuff yields water for domestic and industrial use and to a very slight extent for irrigation in the extreme southeastern part of the county. Flowing wells are obtained in a small area near Bruni. The water generally is highly mineralized.

The Goliad sand is an important source of water for domestic and stock uses in the area of its outcrop in the southeastern part of the county. The water is of variable quality, and the yield of the wells is not very great. The water is generally suitable for domestic use but should not be used for irrigation except after careful testing. 
Quaternary stream deposits in the northeastern part of the county are a source of small amounts of water suitable for domestic use. The wells are shallow.

The investigation showed that the ground waters from all the formations except the Carrizo sand are of variable quality and generally are highly mineralized. Precautions to be taken in using these waters for irrigation are described.

\section{INTRODUCTION}

\section{PURPOSE OF INVESTIGATION}

This report covers the results of an investigation in Webb County, Tex., which was undertaken as part of a State-wide study of the underground-water resources of Texas. The investigation was made by the Geological Survey in cooperation with the Texas Board of Water Engineers and the Engineering Experiment Station of the Agricultural and Mechanical College of Texas. The report is designed to be a practical guide to the ground-water resources of the county, with special reference to the supply of ground water available for irrigation. Many problems of geology and stratigraphy in the area are not considered, because they have little or no bearing on the ground-water supply. The field work occupied June, July, and August in both 1931 and 1932.

\section{ACKNOWLEDGMENTS}

The writers are indebted to many persons who contributed information and assistance in the field and assisted in the preparation of the report. Well logs and well data were supplied by several residents of the county, among them Mr. W. E. Smith, of Laredo; Mr. Ed Roebuck, of Encinal; and Mr. J. B. Finlay, of the Callaghan ranch. Mr. N. W. Jones, county agent of Webb County, extended many courtesies and gave information concerning the agricultural conditions in the area. Messrs. D. D. Davis and Reuben Davis furnished information concerning coal-mining operations near Dolores. Geologists working in the area, Messrs. Olin G. Bell, F. C. Owen, G. B. Gerhardt, and $R$. Ryan, gave freely of their geologic information relating to the area. Miss Julia A. Gardner, of the Geological Survey, identified fossils collected in the area and collaborated in the field work in July and August, 1932. Mr. A. N. Sayre, also of the Geological Survey, who was making a similar investigation in Duval County, spent several days in the field with the writers and gave material assistance in many ways. Mr. W. N. White, who is in charge of the ground-water study in Texas, exercised general supervision of the investigation and gave timely advice and assistance. The investigation was made under the general direction of Mr. O. E. Meinzer, geologist in charge of the division of ground water in the Geological Survey. 


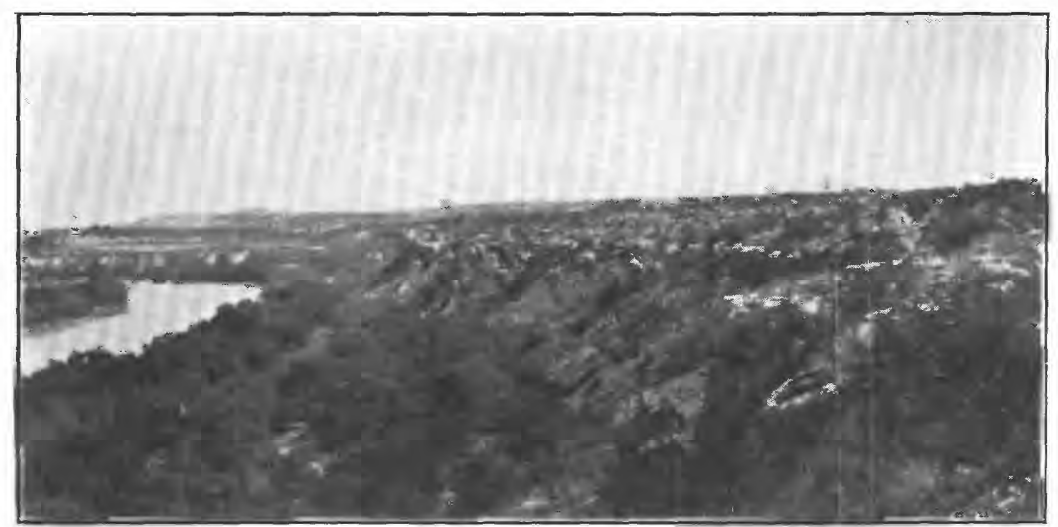

A. BREAKS OF THE RIO GRANDE NEAR PALAFOX.

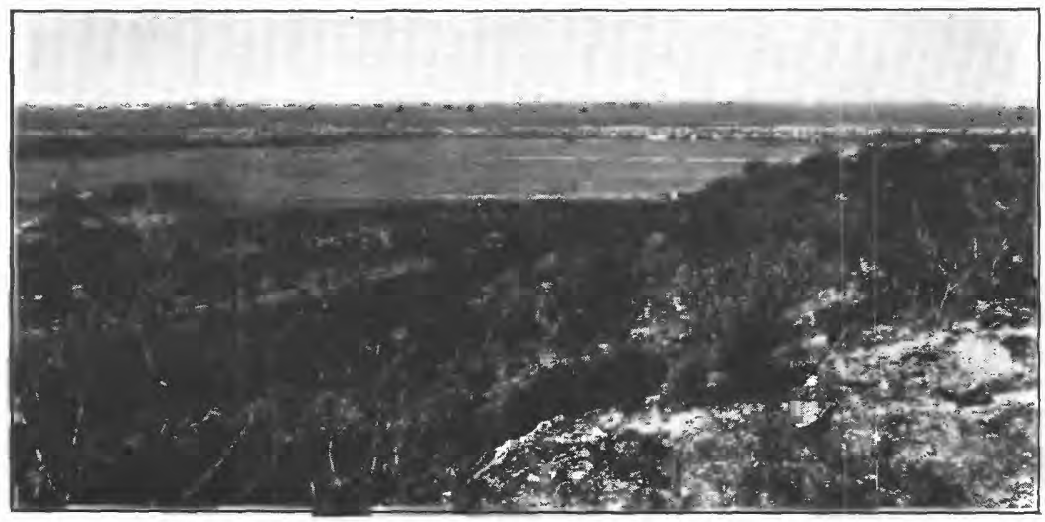

B. BREAKS OF THE RIO GRANDE NEAR PALAFOX. Alluvial flat shown in top of view.

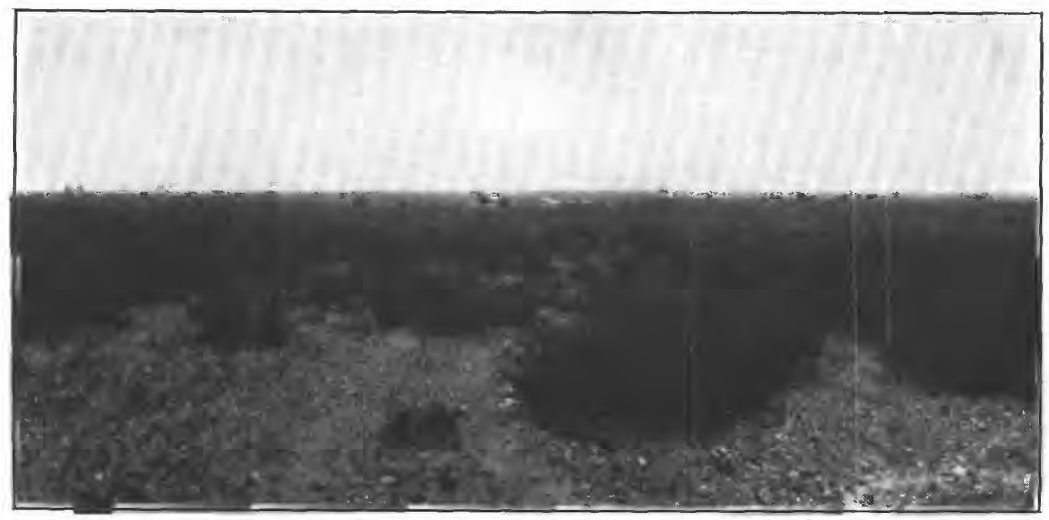

C. DENTONIO PLAIN NEAR GALVAN RANCH. 


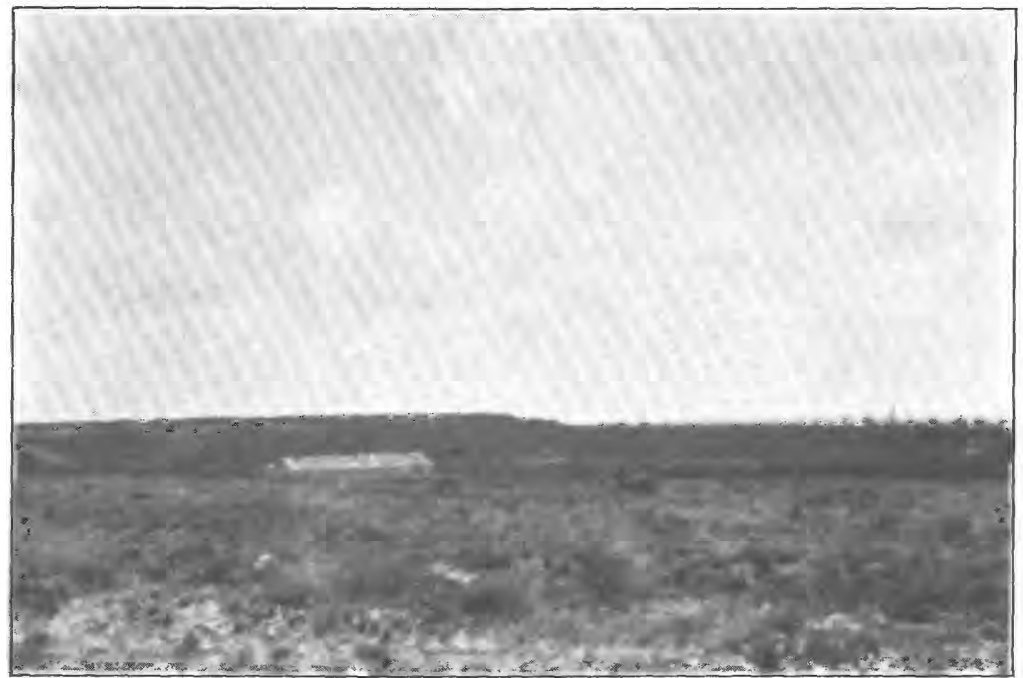

A. BORDAS ESCARPMENT NEAR MIRANDO CITY.

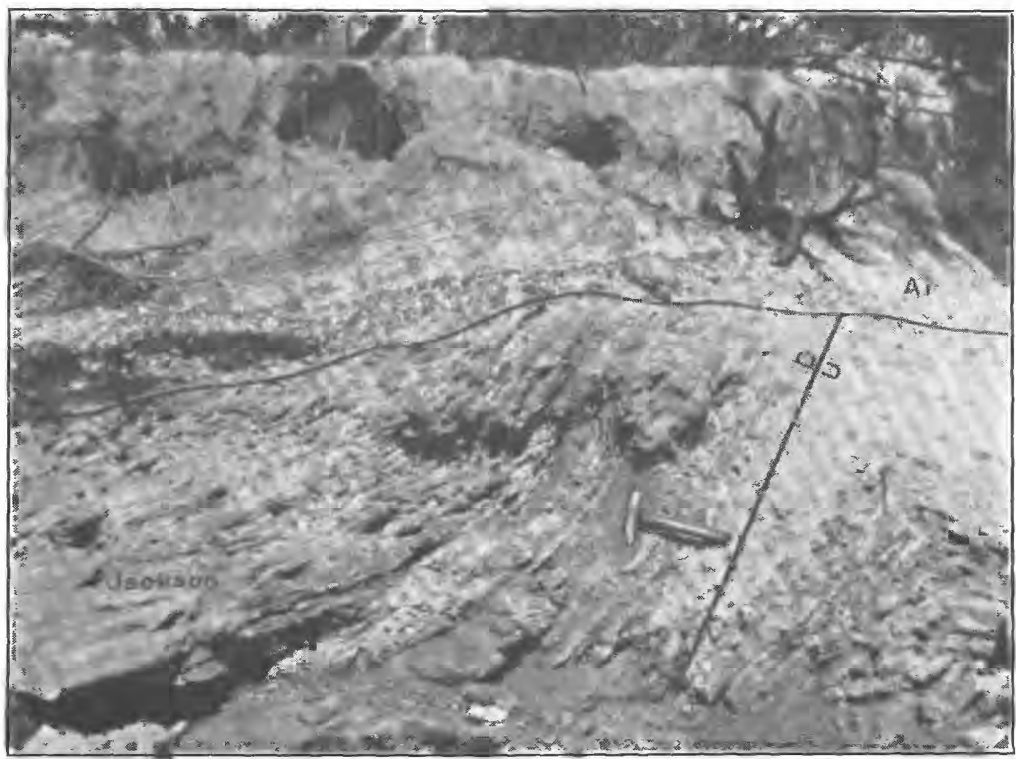

B. BEDS OF THE JACKSON FORMATION UPTURNED AND FAULTED 1.3 MILES SOUTH OF CORPUS CHRISTY HIGHWAY ON RETAMA CREEK.

D, Downthrow; $\mathrm{U}$, upthrow; $\mathrm{Al}$, alluvium. 


\section{IOCATION OF AREA}

Webb County lies in southwestern Texas (see fig. 1) and comprises a part of the district that is commonly called the Winter Garden area, ${ }^{1}$ the boundaries of which are rather loosely defined. Webb County bas an area of 3,219 square miles. Laredo, with a population of 32,618 in 1930 , is the only large city in the county and is an important entry point between the Republic of Mexico and the United

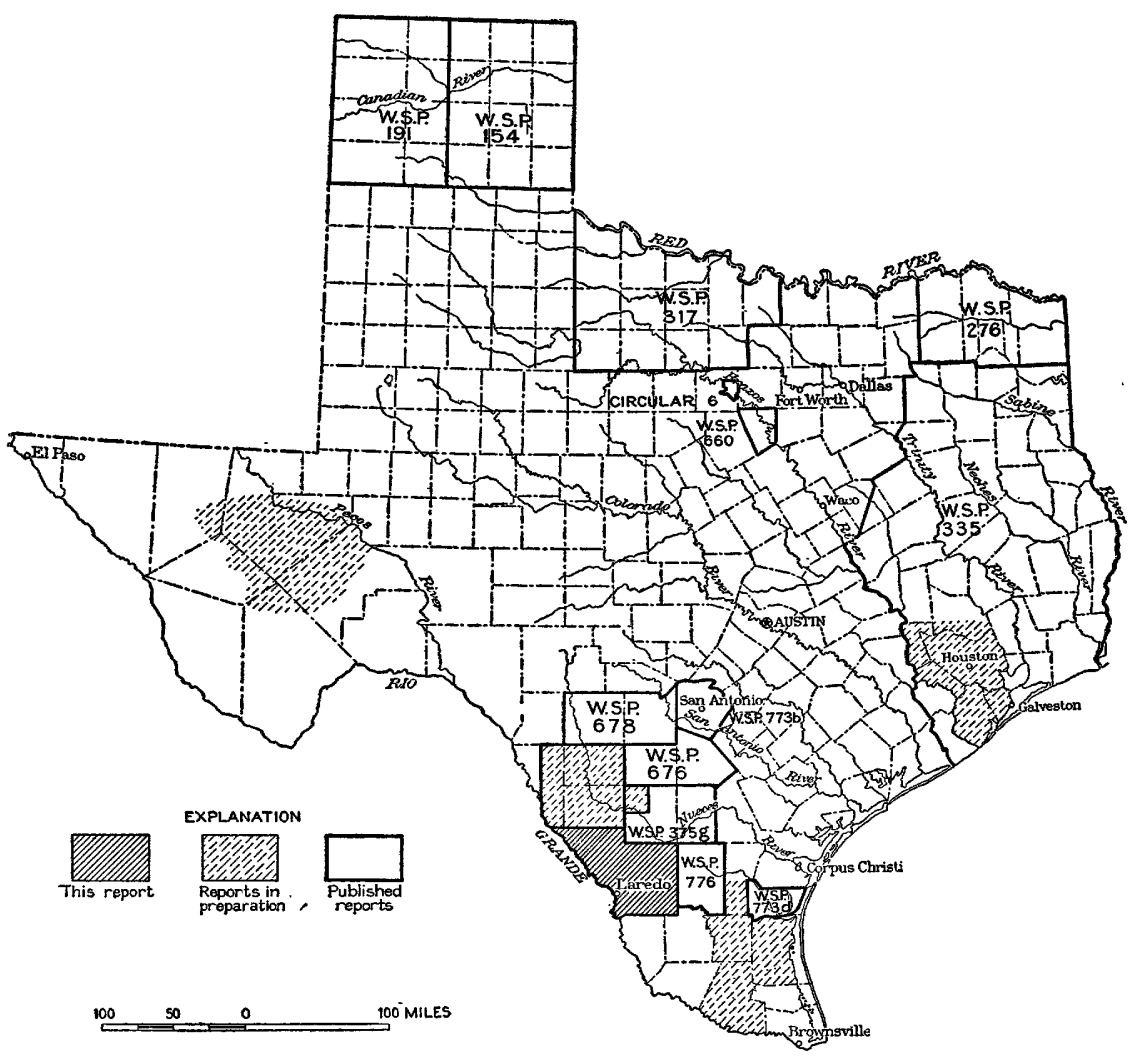

FIGdRE 1.-Map of Texas showing location of Webb County.

States. Mirando City, Oilton, Bruni, and Dolores are the chief smaller settlements.

\section{TOPOGRAPHY AND DRATNAGE}

Webb County lies within the Coastal Plain, which in this part of Texas extends from the Edwards Plateau to the Gulf of Mexico. The county possesses more varied topography than most of the other Coastal Plain counties in southwestern Texas, because of the features of erosion that have been produced by the Rio Grande and its trib-

1 Mortensen, E., The Winter Garden region of Texas: Texas Agr. Exper. Sta. Circ. 62, p. 1, 1933. 
utaries in the western part of the county and the presence of the Bordas escarpment in the southeastern part. The general southeastward slope characteristic of the Coastal Plain is interrupted by these features and by small westward-facing cuestas resulting from the differential erosion of unequally resistant and slightly tilted beds. A consideration of the topography of the Rio Grande region led Trowbridge to recognize, as major topographic divisions in Webb County, the breaks of the Rio Grande, the Nueces Basin, the Dentonio Plain, the Aguilares Plain, and the Bordas escarpment. ${ }^{2}$ A clear conception of these divisions aids in forming a picture of the geography of the area.

Breaks of the Rio Grande.-A belt of land along the Rio Grande that has been intricately dissected by the river and its tributaries is called the breaks of the Rio Grande. In Webb County the belt is from 3 to 15 miles wide and is the roughest part of the country. Along the Rio Grande the lands included in the breaks are from 50 to 125 feet above the river. At some distance from the river they reach a maximum altitude of about 300 feet above it. Streams that enter the Rio Grande in this area are actively eroding. This is indicated by the character of their valleys, which near the Rio Grande are generally narrow and steep-walled but with distance from the river decrease in depth and steepness. The breaks, therefore, form a belt of land cut by a great northwest-southeast trench, the valley of the Rio Grande, and by numerous transverse trenches, the valleys of the tributaries. Cultivable lands are not common in this area, although a few small tracts are found. Views of the breaks are shown in plate $2, A$ and $B$.

Dentonio Plain.- The breaks of the Rio Grande merge on the north and northeast into a nearly flat upland, the Dentonio Plain, which forms the divide between the Rio Grande and the Nueces River. This division is most typically a plain in the area around the Brown ranch, in the northwestern part of the county, where the upland has little or no drainage, has practically no relief, and lacks abundant brush. The character of the topography is indicated by local names, such as Llano [Prairie] Pasture. Farther to the east and southeast the divide between the two rivers is somewhat dissected and the plainlike character is not so evident. Nevertheless, the divide represents a distinct topographic division extending across the area from northwest to southeast. A view of the plain near the Galvan ranch is shown in plate $2, C$.

Nueces Basin.-About half of the county, comprising most of the northern and north-central parts, is drained by tributaries of the Nueces River. These tributaries as a rule are longer and their valleys are broader and shallower than those of the Rio Grande. Some of them

2 Trowbridge, A. C., Tertiary and Quaternary geology of the lower Rio Grande region, Texas: Geol. Survey Bull. 837, pp. 15-24, 1932. 
head within 12 or 15 miles of the Rio Grande. The lands in the Nueces Basin as a rule are comparatively level and therefore are quite in contrast with those in the breaks of the Rio Grande. Many of the valleys contain extensive deposits of alluvium; those in the valley of Prieto Creek are several miles wide and more than 40 feet thick.

Aguilares Plain.-A belt of country several miles wide west of the Bordas escarpment and drained by the Rio Grande is known as the Aguilares Plain. The area is underlain largely by clay or shale with minor amounts of harder rocks. As a result a rolling topography with fairly wide valleys and narrow divides has been developed. The area is too varied in character and has too much relief to be properly classed as a plain. However, it is a topographic unit fairly distinct from surrounding areas and merits a separate designation. It is bounded on the west by the rougher country of the breaks of the Rio Grande.

Bordas escarpment. - The Bordas escarpment is a prominent topographic feature in the southeastern part of the county. It crosses the county in a general northeast-southwest direction from the east county line near Moglia to the south county line near the Aviators oil field. Its position is shown on plate 1 as the contact between the Goliad and Catahoula formations.

The Bordas escarpment is the west face of a cuesta caused by the resistance to erosion of the Goliad sand and underlying formations. It is a notable topographic feature standing from 100 to 200 feet above the Aguilares Plain. The highest point on the escarpment, near Ojuelos, has an altitude of 1,004 feet; the Aguilares Plain at Aguilares, several miles west of the escarpment, has an altitude of about 660 feet. The top of the cuesta is a plain having a gentle slope to the east, called by Trowbridge the Hebbronville Plain. Consequently, the escarpment is noticeable only from the west. An excellent view of it can be obtained from the overpass on the highway west of Aguilares.

In some areas the cuesta does not end in a single escarpment but is continued in two or more lower escarpments flanking the highest point. The lower escarpments are usually formed from hard and resistant beds in the Catahoula formation, and the highest escarpment is usually formed from beds of the Goliad sand. A view of the Bordas escarpment is shown in plate $3, A$.

Drainage.-The Rio Grande is the only perennial stream in this region . The other streams have a flashy, intermittent flow, although the larger ones contain isolated pools of water even in dry periods. The largest tributaries of the Rio Grande in Webb County are San Ambrosia, San Lorenzo, Espada, Santa Isabel, Chacon, and Dolores Creeks. The chief tributaries of the Nueces River are Carrizitos, Parida, Salado, and Prieto Creeks. 


\section{VEGETATION}

The native vegetation reflects to a degree the semiarid character of the climate. Most of the uncleared areas are covered with a growth of varying density of scrub trees or chaparral. On the divides between the streams the trees consist dominantly of mesquite, but on the lowlands near the larger streams pecan, live oak, cypress, willow, and cane are found. The chaparral consists chiefly of blackbrush, catclaw, juahillo, scrub mesquite, and prickly pear and other types of cactus. A variety of grasses grow in open spaces among the trees and chaparral. The character of the vegetation in any locality is influenced by the type of soil produced by the weathering of the underlying formations. A thin growth of chaparral and an abundance of prickly pear and grasses are found on the outcrops of formations composed dominantly of clay. A dense growth of chaparral usually is found on outcrops composed of both sand and clay, and a scattered growth of trees of more than average size is found on outcrops that are dominantly sandy. Gravel-covered areas invariably support dense growths of chaparral.

\section{TRANSPORTATION}

Webb County is traversed by the International-Great Northern Railroad from San Antonio to Laredo; the Texas Mexican Railway from Corpus Christi to Laredo; and the Rio Grande \& Eagle Pass Railway from Laredo to the coal-mining district around Dolores.

The county is provided with good trunk automobile roads-State highway 2 from San Antonio to Laredo along the line of the International-Great Northern Railroad, State highway 12A from Corpus Christi to Laredo, and State highway 4 from Laredo to the lower Rio Grande Valley and Brownsville, following closely the course of the river. A good automobile road also extends from Laredo northwest to the Pilotes ranch. Secondary automobile roads and ranch roads, many of them graded and open for travel except in very wet weather, connect all parts of the area.

\section{AGRICULTURE}

Land in Webb County is used chiefly for stock raising, and large areas probably will always be devoted to this use because of the character of the land, the small amount of rainfall, and the lack of water suitable for irrigation. Farming is on the increase, however, and perhaps eventually most of the land suitable for agriculture will be cultivated. Farming operations in the county at the time of the investigation were mostly restricted to a belt of land a few miles wide along the International-Great Northern Railroad, to lands adjacent to or near the Rio Grande, and to isolated tracts along the Texas Mexican Railway. Irrigation with water from the Rio Grande is carried on in certain areas near this stream, and irrigation with water 
from wells has been developed to some extent along the InternationalGreat Northern Railroad and in isolated small areas in the southern and southeastern parts of the county. The lands irrigated from wells are shown on plate 1 .

The production of winter vegetables and citrus fruit under irrigation from the Rio Grande and to a lesser extent from wells has become an important industry in the area. According to Mortensen, ${ }^{3} 1.9$ percent of the total area of Webb County was under cultivation in 1929. Below is a table compiled from his paper showing the kinds of crops raised and the acreage devoted to each:

Farm acreage of crops raised in Webb County, Tex., in 1929

\begin{tabular}{|c|c|c|c|}
\hline & Acres & & Acres \\
\hline .............. & 331 & | Carrots. & 81 \\
\hline Beans (threshed) & 45 & Corn, sweet. & 11 \\
\hline Corn & 2,351 & Lettuce $\ldots \ldots$ & 22 \\
\hline Cotton & 13,047 & Muskmelons_- & 53 \\
\hline Cowpeas & 16 & Onions, dry & 3,344 \\
\hline Oats & 934 & Onions, green & 266 \\
\hline Peanuts........ & 2 & Spinach & 1,005 \\
\hline Sorghums . & 3,981 & Tomatoes... & 100 \\
\hline Beans, snap & 162 & Turnips_... & 50 \\
\hline Beets & 68 & Watermelons & 124 \\
\hline Broccoli & 150 & Miscellaneous vegetables_....... & 11 \\
\hline Cabbages & 67 & | Fruits__._ & 550 \\
\hline
\end{tabular}

Plate 1 shows the areal geology and hydrologic data for the area including the location of record wells, land irrigated with water from wells, and depths to the top of the Carrizo sand for part of the area. The base map was compiled from tactical maps of the United States Army Engineers, from land maps, and from compass traverses.

\section{CIIMATE}

Texas is remarkable for its great variety of climate. The extreme eastern part of the State has an average annual rainfall of more than 45 inches. The precipitation decreases gradually from east to west, however, the annual average being less than 30 inches at San Antonio and less than 20 inches at Eagle Pass. In Webb County records are available only for Laredo. The average annual rainfall for the whole county probably is about 20 inches.

The seasonal range in temperature in the area is fairly large. Summer temperatures are frequently higher than $100^{\circ}$, whereas during the winter there is generally at least one killing frost. During the period of record the growing season at Laredo has ranged from 225 to 354 days and averaged 293 days. Observations made intermittently since 1871 record a minimum temperature of $5^{\circ}$ above zero.

3 Mortensen, E., op. cit., p. 4. 
In most years there is some rain every month. The heaviest precipitation occurs from April to October, but for any given month there is considerable variation from year to year. There is a tendency for the precipitation to be concentrated in heavy rains, which frequently cause floods. Tables showing available records of rainfall at Laredo, Webb County, and at Encinal, in La Salle County, which adjoins Webb County on the north, are given below. These stations are in the main irrigation districts. Records at other stations in this part of Texas are given in reports of the United States Weather Bureau.

Monthly, annual, and average precipitation, in inches, at Laredo and Encinal, Tex.

Laredo, Webb County

\begin{tabular}{|c|c|c|c|c|c|c|c|c|c|c|c|c|c|}
\hline & Jan. & Feb. & Mar. & Apr. & May & June & July & Aug. & Sept. & Oct. & Nov. & Dec. & Ann. \\
\hline & 1. 50 & 0.00 & 2.25 & 4. 55 & 8.00 & 1.00 & & & & & & & \\
\hline & 2.03 & .46 & 0 & Tr. & 1. 69 & 1.02 & 0.94 & 6.41 & 0.62 & 0.05 & 0.74 & 0.19 & 14.15 \\
\hline & .16 & & $\cdots$ & & & - & - & $\cdots$ & & $\ldots$ & 29 & 2.45 & \\
\hline & .55 & 1.09 & 25 & 01 & 2.29 & 5.18 & 60 & 1.48 & 5.93 & 5. 68 & 1.10 & .84 & 25. \\
\hline & .02 & .88 & 1. 33 & 2. 20 & 12.20 & .53 & 34 & 2.80 & .31 & 4. 18 & 4. 79 & .80 & 30. \\
\hline & 3.57 & .21 & .75 & 2. 16 & 4.15 & & & 4.76 & 2.14 & 4. 50 & .04 & 3 & 22. \\
\hline & 1. 63 & 0 & & 34 & .07 & .15 & 3.8 & 4. 74 & 3. 71 & 3. 58 & .35 & & 18. \\
\hline & .20 & & & 10 & 1.47 & & .15 & 1.47 & .97 & .06 & & & 4. \\
\hline & 0 & .70 & .28 & 1. 12 & 4. 55 & 84 & 18 & 1.69 & .53 & 2. 30 & 1.44 & .38 & 14. \\
\hline & 1. 12 & 2. 55 & 1.3 & 2. 69 & 2. & 4.87 & 10. $2 S$ & .06 & 10.15 & 9. & 6.14 & .76 & \\
\hline & 1.87 & 11 & .2 & .05 & 2. & 1.49 & .68 & .79 & 1.20 & 1.65 & .80 & 01 & 11. \\
\hline & .16 & Tr. & 1.0 & .20 & 2. & 2.37 & 1.07 & Tr. & 6. & & & & 13. \\
\hline & .10 & .2 & .1 & .96 & 5. & 5.44 & 1.9 & .40 & & 1. & .62 & .01 & 18. \\
\hline & .38 & 5.80 & 2.1 & .38 & $\therefore$ & 1.16 & .43 & .90 & 8. & 2.13 & 2.49 & 3.12 & 28. \\
\hline & .59 & 1.1 & 1 & .08 & 3. & 1. & & & 2. & & & & 10. \\
\hline & .27 & & 1.6 & .11 & 1. & 1. & $\therefore$ & 3.5 & 7. 44 & & 1. & & \\
\hline & 4. 21 & 0 & 2.0 & 1. 73 & 4. & 1. & 3.5 & .4 & $\therefore 0$ & 2. & 1. & 2. & 24. \\
\hline & .68 & .75 & 1.2 & .9 & 1. & 3.3 & .3 & 1. & 1. & .6 & 3 & 1.42 & 13. \\
\hline & 2. 36 & 2.42 & .3 & .55 & 9. & .15 & .9 & .52 & 2. & .8 & 2.9 & 2. & 25. \\
\hline 19 & .23 & .62 & 1.77 & 1. 49 & 4.8 & . 98 & .88 & Tr. & 1.59 & .85 & 1. 31 & 1.62 & 16. \\
\hline 1930 & .3 & & .74 & 1.90 & 3. 46 & 2. 31 & .21 & .14 & 3.51 & 6.74 & 3.65 & .15 & 23. 99 \\
\hline Ar & 1.05 & .89 & .90 & 1.08 & 3. 75 & 1.71 & 1. 40 & 1.67 & 3. 23 & 2. 54 & 1. 51 & 1.11 & 20.84 \\
\hline
\end{tabular}

Encinal, La Salle County

\begin{tabular}{|c|c|c|c|c|c|c|c|c|c|c|c|c|c|}
\hline 1907 & & & & & & & & & & 2.06 & 2. 21 & 0. 38 & \\
\hline 1908 & 0.35 & 0.20 & 0.97 & 8.75 & 1.08 & 0.18 & 3. 82 & 2.13 & 1. 98 & 2. 18 & 1. 37 & & 23.01 \\
\hline 1909 & $\mathrm{Tr}$. & 75 & .29 & .74 & 4. 32 & .99 & 1.81 & 3.27 & & & .37 & 1.94 & 14. 98 \\
\hline 1910 . & 1.13 & .08 & .78 & .35 & 2. 23 & 1. 67 & 1.24 & 1.00 & 1.09 & 1. 33 & .46 & 1 & 12.07 \\
\hline 191 & $0^{.35}$ & $\begin{array}{l}1.43 \\
70\end{array}$ & 2.16 & 2. 09 & .63 & 0 & & & 4 & & & & $21=7$ \\
\hline $\begin{array}{l}191 \\
191\end{array}$ & 0 & .70 & 1.05 & 3.65 & 3.65 & 5.95 & 0 & 0 & - & 4. 20 &. & 1.85 & 21.57 \\
\hline $\begin{array}{l}1913 \\
1914\end{array}$ & 1.15 & & 1. & & & 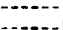 & & & - & 7,30 & 6.10 & $-\ldots$ & - \\
\hline 1915 & 2.00 & 1.02 & 11 & 5.52 & 1.19 & & & 1.22 & 2.25 & 2.00 & & 08 & 15.39 \\
\hline 1916 & .60 & .01 & .50 & .52 & .62 & $\mathrm{Tr}$ & 3. 73 & 9.46 & 2. 71 & .82 & .50 & & 19.47 \\
\hline 191 & .34 & & .24 & 1. 17 & .25 & .41 & .58 & .03 & 3.30 & & .40 & & 6.72 \\
\hline 19 & .20 & .28 & .50 & .78 & 2.70 & .35 & .14 & .11 & 2.77 & 2. 69 & 2.05 & 1. 29 & 13.85 \\
\hline 19 & 1. 84 & 1. 79 & 2.78 & 2.60 & 3.35 & 5. 90 & 4. 59 & 1. 66 & 11. 65 & 7.74 & 2.16 & .89 & 46.95 \\
\hline 19 & 3. 38 & .38 & .36 & $\mathrm{Tr}$ & 2. 64 & 1. 08 & .67 & 2. 78 & 1.92 & 1.42 & 1. 24 & & 15.87 \\
\hline -. & .30 & .28 & 1. 22 & 1.07 & 2. 69 & 1. 16 & 134 & Tr. & 4. 61 & .05 & .23 & .33 & 13. 28 \\
\hline - & .37 & .75 & 3.80 & 1.10 & 1. 54 & 9.79 & 1.56 & 86 & 2. 90 & 4. 67 & 84 & .08 & 28.26 \\
\hline 19 & .70 & 7.87 & 3. 61 & .87 & .02 & .82 & 2. 03 & 1.11 & 8.35 & 1.52 & 3. 36 & 3.77 & 34.03 \\
\hline 19 & .52 & 2.05 & .58 & 69 & 3.99 & 2.63 & .01 & & 5.62 & .22 & 0 & 2.10 & 18.41 \\
\hline 192 & .08 & & 4. 15 & .16 & 3.35 & $\mathrm{Tr}$. & 20 & 1.75 & 6.36 & 1. 70 & .92 & 1.95 & 20.62 \\
\hline 192 & 3.20 & .35 & 3.33 & 1.12 & 2. 33 & .98 & 7.76 & 1. 18 & & 3.80 & .98 & 1.57 & 27.39 \\
\hline 1927 & .89 & .55 & 1.02 & .44 & .80 & 1. 14 & .80 & .75 & 1.85 & 10.90 & .07 & 1.27 & 20.48 \\
\hline 1928. & 3. 40 & 2.80 & .27 & .70 & 5.65 & .03 & .91 & 1.20 & 3.67 & .19 & 1.22 & 2. 59 & 22.63 \\
\hline 929 & .24 & .10 & 2.31 & .70 & 3.20 & 1. 12 & 0 & .04 & 1.26 & 42 & 3.53 & 2.37 & 15.92 \\
\hline 930 & .59 & .48 & 1.45 & 2. 39 & 3.50 & 4.01 & .7 & Tr. & .58 & 3.72 & 3. 75 & .16 & 21.36 \\
\hline Average.... & .98 & 1.07 & 1.50 & 1.61 & 2. 37 & 1.82 & 1.63 & 1. 43 & 3.20 & 2. 70 & 1.45 & 1.11 & 20.87 \\
\hline
\end{tabular}


Frost data at stations in southwestern Texas

\begin{tabular}{|c|c|c|c|c|c|c|}
\hline Station & $\begin{array}{l}\text { Length } \\
\text { of } \\
\text { record } \\
\text { (years) }\end{array}$ & $\begin{array}{l}\text { Average } \\
\text { date of } \\
\text { last } \\
\text { killing } \\
\text { frost in } \\
\text { spring }\end{array}$ & $\begin{array}{l}\text { Average } \\
\text { date of } \\
\text { first } \\
\text { killing } \\
\text { frost in } \\
\text { autumn }\end{array}$ & $\begin{array}{l}\text { Average } \\
\text { length of } \\
\text { growing } \\
\text { season- } \\
\text { last kill- } \\
\text { ing frost } \\
\text { to first } \\
\text { killing } \\
\text { frost } \\
\text { (days) }\end{array}$ & $\begin{array}{l}\text { Latest } \\
\text { date of } \\
\text { killing } \\
\text { frost in } \\
\text { spring }\end{array}$ & $\begin{array}{l}\text { Earliest } \\
\text { date of } \\
\text { killing } \\
\text { frost in } \\
\text { autumn }\end{array}$ \\
\hline $\begin{array}{l}\text { Carrizo Springs. } \\
\text { Eagle Pass } \\
\text { Encinal } \\
\text { Fort MeIntosh. } \\
\text { Llano Grande } \\
\text { Pearsall }\end{array}$ & $\begin{array}{r}6 \\
38 \\
21 \\
46 \\
8 \\
10\end{array}$ & $\begin{array}{l}\text { Feb. } 26 \\
\text { Feb. } 27 \\
\text { Feb. } 23 \\
\text { Feb. } 14 \\
\text { Mar. } 5 \\
\text { Feb. } 23\end{array}$ & $\begin{array}{lr}\text { Dec. } & 6 \\
\text { Nov. } & 26 \\
\text { Dec. } & 6 \\
\text { Dec. } & 4 \\
\text { Dec. } 15 \\
\text { Nov. } 24\end{array}$ & $\begin{array}{l}283 \\
272 \\
286 \\
293 \\
285 \\
274\end{array}$ & $\begin{array}{lr}\text { Mar. } & 23 \\
\text { Apr. } & 5 \\
\text { Apr. } & 5 \\
\text { Apr. } & 5 \\
\text { Mar. } 25 \\
\text { Mar. } 17\end{array}$ & $\begin{array}{lr}\text { Nov. } & 15 \\
\text { Oct. } & 20 \\
\text { Oct. } & 30 \\
\text { Oct. } & 28 \\
\text { Nov. } & 2 \\
\text { Nov. } & 13\end{array}$ \\
\hline
\end{tabular}

\section{PREVIOUS WORK}

No previous work on the ground-water resources of Webb County has been published except a report by Taylor ${ }^{4}$ covering all of southwestern Texas. Taylor's report lists only two wells in Webb County.

A large number of papers and reports describing the geology of southwestern Texas, including Webb County, have been published. These include both pioneer work and later more detailed work. Trowbridge $^{5}$ has listed most of these publications, and it is not necessary to cite all of them here. Recent reports of great importance that will be mentioned frequently in the present report are those by Bailey ${ }^{6}$ and Trowbridge. ${ }^{7}$ Other reports will be cited in the appropriate sections.

\section{GENERAL GEOLOGY}

The rock formations exposed in Webb County are of Tertiary and Quaternary age. Upper Cretaceous formations have been encountered in deep wells drilled for oil in the northwestern part of the area, and they probably everywhere underlie the excesed formations. There are many problems of stratigraphy and correlation in the area, but most of them are not within the scope of this report. Plate 1 shows the outcrops of the formations except deposits of late Pliocene (?) and Quaternary gravel and Recent alluvium, which ordinarily do not contain notable supplies of ground water and therefore are not important in a consideration of the ground-water resources. Plate 1 also shows cross sections in which the structure of the area is delineated. The geologic table at page 14 shows the relations and characteristics of the several formations present.

\footnotetext{
4 Taylor, T. U., Underground waters of the Gulf Coastal Plain of Texas: Geol. Survey Water-Supply Paper 190, 1907.

$\checkmark$ Trowbridge, A, C., op. cit., pp. 2-7.

6 Bailey, T. L., The Gueydan, a new middle Tertiary formation from the southwestern Coastal Plain of Texas: Texas Univ. Bull. 2645, 1926.

7 Trowbridge, A. C., A geologic reconnaissance in the Gulf Coastal Plain of Texas near the Rio Grande: Geol. Survey Prof. Paper 131, pp. 86-107, 1923.
} 
The Upper Cretaceous formations are believed to be unimportant with reference to ground-water supply, because they are generally encountered at depths that are too great for economical drilling. Hence no attempt is made here to give detailed descriptions or correlations of these formations. No oil test well has penetrated to the bottom of the Tertiary formations in Webb County east of the International-Great Northern Railroad.

The Oakville sandstone and Lagarto clay are not shown on plate 1, either on the map or in the cross sections. In areas northeast of Webb County these formations are present between the Catahoula and Goliad formations, and geologic maps of Webb County by Trowbridge and Bailey show the Oakville sandstone cropping out along the face of the Bordas escarpment.

In the course of the present work the conclusion has been reached that the Oakville sandstone does not occur in Webb County. The rocks that have been classified as Oakville in previous reports are now considered to be either Goliad, Catahoula, or chalcedonic dikes and plugs. It is possible that the Oakville and Lagarto formations are present beneath the Goliad sand in the extreme eastern part of Webb County, as the Goliad overlaps older formations. Well logs and other available data, however, do not yield conclusive evidence with regard to the question.

The general geologic structure of the area is comparatively simple. The most prominent feature is a general Gulfward dip of the formations, at a greater angle than the slope of the land surface. The direction of the dip is somewhat variable, being essentially east in the northwestern and north-central parts of the county and northeast in the southern part, southeast of Laredo. The general structure of the Webb County area is a consequence of its position in the Rio Grande embayment. This feature was a basin of deposition during Tertiary time, and when subsequently the region was elevated the basin character was retained in the structure of the rocks. Webb County is on the southwest flank of the Rio Grande embayment, and accordingly the rock formations generally dip east, southeast, or northeast into the basin.

A considerable number of minor structural features are superimposed upon the general simple structure of the area. These minor features cause local reversals in direction and amount of dip and strike of the formations, but they do not greatly affect the occurrence or movement of the ground water. Those mapped during the course of the field work are briefly discussed below and are shown on plate 1 .

1. A fault affecting strata of the Cook Mountain formation is exposed 6 miles northwest of Laredo, in a bluff along the Rio Grande, and has been traced for 1 mile northeast from the river. The displacement of the strata is about 60 feet. The fault is shown in the cross sections on plate 1 . 
2. A gentle anticlinal fold occurs in the vicinity of Dolores, Darwin, Santo Tomas, and Minera. This has caused north dips in the strata near Darwin and Santo Tomas. Altitudes on key horizons are 20 feet higher in the vicinity of Minera and Darwin than a few miles northwest. This fold has caused the contact of the Bigford member with overlying Mount Selman strata to swing eastward in this vicinity.

3. A small thrust fault is exposed just south of sec. $28,0.1$ mile south of the goat-camp crossing on San Lorenzo Creek, in the northwestern part of the county. The fault plane dips $8^{\circ}$ at the bottom and $19^{\circ}$ at the top and has a strike of N. $15^{\circ} \mathrm{W}$. The displacement is about 2 feet.

4. A fault is exposed in the Thomas pasture 3 miles east of the road between Dolores and the Pilotes ranch and 3 miles north of the old Wayne ranch. The fault strikes $\mathrm{N} .13^{\circ} \mathrm{W}$. and has a maximum displacement of 25 feet.

5. Two faults cut the Cerritos Blancos north of Dolores. One has a strike of N. $30^{\circ}$ E., with a displacement of 70 to 90 feet and the upthrown side on the east. The other strikes due north and has a displacement of 60 feet and an upthrow on the east.

6. A fault occurs 1 mile south of the Cerritos Blancos. The strike is $\mathrm{N} .13^{\circ} \mathrm{E}$., and the displacement is 15 to 25 feet, with the upthrown side on the southeast.

7. A fault $1 \frac{1}{2}$ miles south of the Tordillo ranch strikes N. $19^{\circ}$ E., and the displacement is 20 feet with the upthrown side on the southeast.

8. A fault 0.6 mile northwest of Minera strikes N. $10^{\circ} \mathrm{W}$., and the displacement is 2 feet, with the upthrown side on the east. It cuts the Santo Tomas coal bed.

9. At a point 0.4 mile west of the coal prospect on Espada Creek and 1.4 miles east of Little Apache Hill a sandstone stratum dips $45^{\circ} \mathrm{W}$. There is little or no indication of displacement of the strata.

10. Several small faults with displacements of 4 feet or less are reported in the coal mines at Dolores, Darwin, and Minera.

11. Southeast of Encinal an eastward swing of the Cook MountainYegua contact seems to indicate the presence of a nose or decrease in the amount of dip. The dip changes from about $1^{\circ}$ to horizontal, or possibly there is a slight reversal of the dip.

12. A fault on Retama Creek 1.4 miles south of the Corpus Christi highway strikes $N .70^{\circ} \mathrm{W}$., and the upthrow is to the northeast. The fault plane dips $52^{\circ} \mathrm{SW}$. Steep dips in ashy beds of the Jackson formation 1 mile east of this point may be a continuation of the same fault. A view of the fault is shown in plate $3, B$.

13. A small fault is exposed on the road leading north from Bruni at a point 3.1 miles south of the Gates ranch.

14. The presence of siliceous dikelike bodies of rock in the eastern part of the Callaghan ranch may indicate unusual structural condi105575-37-2 
tions. There are also indications of unusual structural conditions along the contact of the Yegua and Jackson deposits east and southeast of the Callaghan ranch headquarters. No detailed mapping of these features has been done.

In the eastern part of the area numerous anticlinal folds and faults have caused accumulations of petroleum and natural gas. These have been described in detail by Trowbridge. ${ }^{8}$ Deussen ${ }^{9}$ has described an uplift of about 200 feet centering around Oilton (Torrecillas) as the Torrecillas uplift. At this point the base of the Goliad sand is much higher than elsewhere. It is possible that the productive oil and gas structural features of the region are related in origin to the Torrecillas uplift.

Probably many additional faults and anticlines are present in the area. Exposures in many places suggest such conditions, but detailed mapping of these features was beyond the scope of this report, especially in areas where the strata are not water bearing.

\section{SOURCE AND DISPOSAL OF THE GROUND WATER}

The fundamental principles governing the occurrence and movement of ground water have been discussed in detail by Meinzer, ${ }^{10}$ and only essential statements will be made in this section of the report.

The ground water is derived chiefly from the water that falls as rain or snow. A part of this water runs off directly in streams to the sea, a part evaporates, a part is consumed by plants, and a part sinks to the ground-water table and enters the zone of saturation. Most of the water in the zone of saturation is eventually returned to the surface through springs or wells or is discharged by plants or through evaporation from the soil when it approaches the surface. Some water, however, percolates directly into the sea. The water table differs in altitude from place to place and fluctuates as a result of variation in rainfall, evaporation, and other climatic conditions.

The porous rocks below the water table are as a rule saturated with water and yield water to wells sunk into them wherever the rocks are of such a texture that the water is free to move into the wells. In the more permeable rocks, such as coarse sandstone and gravel, the water is free to move under the influence of gravity, but in the less permeable rocks, such as shale and fine-grained sandstone, molecular attraction tends to retard movement of the water.

${ }^{8}$ Trowbridge, A. C., op. cit. (Bull. 837), pp. 237-251.

8 Deussen, Alexander, Geology of the Coastal Plain of Texas west of Brazos River: Geol. Survey Prof. Paper 126, pp. 124-126, 1924.

10 Meinzer, O. E., The occurrence of ground water in the United States, with a discussion of principles: Geol. Survey Water-Supply Paper 489, 1923; Outlines of ground-water hydrology: Geol. Survey WaterSupply Paper 494, 1923. 


\section{GENERAL ARTESIAN CONDITIONS}

The conditions governing artesian water are discussed in numerous reports of the United States Geological Survey ${ }^{11}$ and State geological surveys and in many textbooks of geology. If a permeable stratum in an inclined position, lying between relatively impervious or watertight strata, receives water from rainfall or stream flow at its outcrop, the water entering it will move under the influence of gravity down the dip of the stratum and will tend to accumulate under hydrostatic pressure. Flowing wells may be obtained where the pressure is sufficient to raise the water to the surface. Whether flowing wells can be obtained in any particular locality that is underlain by an artesian stratum will depend on the difference in altitude and the horizontal distance between that locality and the outcrop area, and also on the effectiveness of the confining beds.

In an artesian system in general, the source of water is that entering at the outcrop of the permeable formation. The artesian system loses water through springs or other natural discharge and through wells sunk to the permeable formation. If the amount of water lost from the artesian system in any period exceeds the recharge during the same period the head will become lower. If too many wells are sunk the head may decline so much that the water will have to be raised by pumping from so great a depth that the cost of pumping may become excessive. Thus there is a limit to the economical development of any artesian system. This limit is approached or may already be exceeded if the water levels in wells become lower and lower from year to year, and such overdevelopment will affect unfavorably all who use water from the artesian system.

\section{GROUND-WATER CONDITIONS IN WEBB COUNTY}

The structure of the rocks in Webb County is favorable for the occurrence of artesian water, but the conditions are such that in only a few localities can flowing artesian wells be obtained. In the greater part of the county the water in wells rises to levels considerably above the permeable bed but not to the surface.

The formations are composed largely of permeable sandstone interbedded with relatively impermeable clay and shale. Except in localities where there are notable folds or faults, the rocks dip to the east, southeast, or northeast. Successively younger formations are encountered in crossing the county from west to east, or from northwest to southeast. Each formation has an outcrop area, from which it extends toward the east, southeast, or northeast, below the younger formations, to progressively greater depths below the surface (pl. 1).

\footnotetext{
11 Chamberlin, T. C., The requisite and qualifying conditions of artesian wells: Geol. Survey 5th Ann. Rept., pp. 125-173, 1885. Fuller, M. L., Summary of the controlling factors of artesian flows: Gecl. Survey Bull. 319, 1908.
} 
Thus the formations that appear at the surface in the northwestern. part of the county occur at depths of several thousand feet in the central part, and formations that appear at the surface in the central part of the county occur at depths exceeding 2,000 feet in the eastern part. The Carrizo sand, for example, reaches a depth of more than 2,500 feet near Webb, and the Cook Mountain formation reaches a. depth of more than 2,000 feet on the Green Martin ranch.

The Cook Mountain formation has been more extensively exploited. for water than any other formation in the area, but the Carrizo sand is potentially more productive. Considerable supplies of water are. also obtained from the Catahoula and Goliad formations and, in the valleys of some of the streams, from alluvium. Flowing artesian wells are obtained in small areas from the Cook Mountain and Catahoula formations. The Carrizo sand possesses fairly uniform characteristics over fairly wide areas, and the hydrologic characters of the formation can be accurately delineated (pl. 1). The other water-yielding formations vary considerably in lithology and stratigraphy from place to place, and the aquifers in them cannot be as accurately described as. that of the Carrizo.

\section{GEOLOGIC FORMATIONS AND THEIR WATER-BEARING PROPERTIES}

A generalized section of the geologic formations that underlie this area is given in the accompanying table. The formations are listed in the order in which they lie beneath the surface, each successive formation being older than the one above it.

Following is a discussion of the formations, giving the areal extent of their outcrop areas, their general features as regards lithology and petrography, paleontology, thickness, and dip, and the quality and quantity of water that they yield. The formations are discussed in the order in which they were laid down and in which the outcrops are successively crossed in traveling from west to east or northwest to. southeast across the area.

\section{TERTIARY SYSTEM}

EOCENE SERIES

WILCOX GROUP

INDIO FORMATION

Areal extent.-The Indio formation crops out in a small triangular area in the extreme northwestern part of the county (pl. 1). It is exposed along the Rio Grande from the north boundary of the county southeastward to a point near Frijolita Spring, on the Chupadero. ranch, a distance of about 10 miles. The formation lies unconformably beneath the Carrizo sand. 
Rock formations in Webb County, Tex., and their water-bearing properties

\begin{tabular}{|c|c|c|c|c|c|c|c|}
\hline System & Series & \multicolumn{3}{|c|}{ Group, formation, and member } & $\begin{array}{l}\text { Maxi- } \\
\text { mum } \\
\text { thick- } \\
\text { ness } \\
\text { (feot) }\end{array}$ & Lithologic aharacter & Ground-water conditions \\
\hline Quaternary. & Recent. & \multirow{2}{*}{\multicolumn{3}{|c|}{$\begin{array}{l}\text { Alluvium. } \\
\text { - Unconformity - } \\
\text { Uvalde gravel. }\end{array}$}} & 50 & Stream-deposited sand, gravel, and silt. & $\begin{array}{l}\text { Alluvium along streams yields variebile } \\
\text { amounts of water. Quality varies, but } \\
\text { in some places the water is suitable for } \\
\text { domestic use. }\end{array}$ \\
\hline Tertiary (?). & Pliocene (?). & & & & 25 & Gravel, conglomerate, sand, and calliche. & Not known to yield water. \\
\hline \multirow{5}{*}{. } & Pliocene. & \multicolumn{3}{|c|}{ Goliad sand. } & 100 & $\begin{array}{l}\text { Reddish sand, caliche, and conglomerate } \\
\text { with minor amounts of clay. Sand } \\
\text { and conglomerate may be indurated } \\
\text { to quartzite. }\end{array}$ & $\begin{array}{l}\text { Sand and conglomerate yield variabl } \\
\text { amounts of water at shallow deptss in } \\
\text { southeastern part of county. Qualit } \\
\text { variable; usually suitable for demesti } \\
\text { use. }\end{array}$ \\
\hline & Miocene (?). & \multicolumn{3}{|c|}{ Catahoula tuff. } & 750 & $\begin{array}{l}\text { Predominantly pyroclastic rocks; tuffa- } \\
\text { ceous sandstone and conglomerate; } \\
\text { whitish tuff, grayish and pinkish silic- } \\
\text { ified tuff, purplish and greenish ben- } \\
\text { tonitic clay. Minor amounts of non- } \\
\text { volcanic sandstone and clay are pres- } \\
\text { ent. Bandstone beds up to } 20 \text { feet in } \\
\text { thickness. }\end{array}$ & 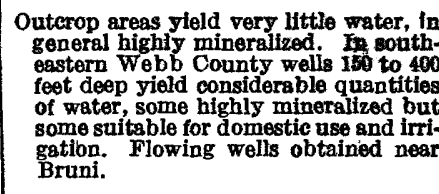 \\
\hline & Oligocene (?). & Frio & clay. & & $\stackrel{250}{\because}$ & $\begin{array}{l}\text { Greenish and grayish clay and sandy } \\
\text { clay. }\end{array}$ & Not known to yield water. \\
\hline & \multirow{7}{*}{ Eocene. } & \multicolumn{3}{|c|}{ Jackson formation. } & 1,500 & $\begin{array}{l}\text { Grayish, green, and buff olay, gray to } \\
\text { buff sandy clay, buff to light-grayish } \\
\text { sandstone, light-gray to white ashy } \\
\text { sandstone, and light-gray to white vol. } \\
\text { canie ash. Ashy beds contain plant } \\
\text { fossils. Scanty invertebrate fauna. }\end{array}$ & $\begin{array}{l}\text { Yields variable amounts of highly min. } \\
\text { eralized water. }\end{array}$ \\
\hline & & \multirow{2}{*}{\multicolumn{3}{|c|}{ Cook Mountain formation. }} & 670 & $\begin{array}{l}\text { Gray to yellowish and chocolate-brown } \\
\text { clay, sandy clay, thin beds of sand- } \\
\text { stone, secondary gypsum, and lime- } \\
\text { stone concretions. }\end{array}$ & $\begin{array}{l}\text { Yields small quantities of highly miner- } \\
\text { alized water. }\end{array}$ \\
\hline \multirow[t]{5}{*}{ Tertiary. } & & & & & 670 & $\begin{array}{l}\text { Sandstone, glauconitic sendstone, glan- } \\
\text { conitic marl, and alay. Some of the } \\
\text { clay is gypsiferous. Lower half domi- } \\
\text { nantly sandy; upper half dominantly } \\
\text { clay. Many fossiliferous beds with } \\
\text { rich faunas. }\end{array}$ & $\begin{array}{l}\text { Sandetone of lower part constitutes' } 7 m- \\
\text { portant aquifer, yielding variable } \\
\text { amounts of water of variable quality. } \\
\text { Some Cook Mountain water suitable } \\
\text { for irrigation. Flowing wells obtained } \\
\text { in low areas in northeastern part of } \\
\text { Webb County. }\end{array}$ \\
\hline & & 送 & Mount & Opper part. & 1,165 & $\begin{array}{l}\text { Dominantly ciay with minor beds of } \\
\text { sandstone. Ooal beds common. Spar- } \\
\text { ingly fossiliferous. }\end{array}$ & $\begin{array}{l}\text { Ylelds small amounts of highly minieral } \\
\text { ized water. }\end{array}$ \\
\hline & & & $\begin{array}{l}\text { forma- } \\
\text { tion. }\end{array}$ & Bigford member. & 660 & $\begin{array}{l}\text { Dark-brown to buft and gray gypsifer- } \\
\text { ous clay, thin-bedded to massive vart- } \\
\text { colored sandstone, concretionary lime- } \\
\text { stone, lignite, and cannel coal. Spar- } \\
\text { ingly fosslififerous. }\end{array}$ & $\begin{array}{l}\text { Sandstone supplies moderate amounts of } \\
\text { water that is genersily too salty for any } \\
\text { use exceppt stock. }\end{array}$ \\
\hline & & & \multicolumn{2}{|c|}{ Carrizo sand. } & 250 & $\begin{array}{l}\text { Gray to buff medium to cosirse sandstone } \\
\text { with minor lenses of olay and shale. }\end{array}$ & $\begin{array}{l}\text { Generally y'elda large quantities of water } \\
\text { suftibblo lor all uses. }\end{array}$ \\
\hline & & $\begin{array}{c}\text { Wib- } \\
\text { cox } \\
\text { group }\end{array}$ & \multicolumn{2}{|c|}{ Indio formatton. } & 1850 & $\begin{array}{l}\text { Thin sandatone, laminated carbonaceous } \\
\text { clay and shale, and lignite. }\end{array}$ & $\begin{array}{l}\text { Yiledds amall quantities of highly miner } \\
\text { alteed water suitable only for stock. }\end{array}$ \\
\hline
\end{tabular}

1250 feot exposed in Webb County. 

Lithology.-The Indio formation consists chiefly of thin-bedded or laminated sandy shale and shaly sandstone with subordinate amounts of purer shale, clay, and sandstone. The sandstone is gray, yellow, or chocolate brown and is generally medium- to fine-grained. The clay and shale are gray or brown and in many places are stained yellow. Locally they show very fine laminations and can be classed as paper shales. Carbonaceous material is not uncommon in the formation. Lignite beds are found in some places, and biscuit-shaped concretions are common.

Thickness.-The total thickness of the Indio formation in a well in Dimmit County, which adjoins Webb County on the north, has been estimated by Getzendaner ${ }^{12}$ as 815 or 877 feet. Only the upper 250 feet is exposed in Wobb County.

Fossils.-The formation contains a few species of Foraminifera and larger forms and fossil leaves, but no collections have been made from localities in Webb County. ${ }^{13}$

Sections.-Numerous sections of the formation are exposed along the Rio Grande and its tributaries. A section exposed at the junction of the east fence of the Indio ranch and the Rio Grande, 2.9 miles southeast of the northwest corner of Webb County, is probably typical of the formation as developed in Webb County.

Section of Indio formation at junction of east fence of Indio ranch and Rio Grande

Sandstone in beds as much as 4 inches thick
Gypsiferous sandstone and shale, in paper-thin laminations,
stained yellow
Massive sandstone with horizontal thin ferruginous layers
Sandstone in beds as much as 4 inches thick

West of the Chupadero ranch the road crosses San Ambrosia Creek on a layer of fine-grained quartzitic sandstone containing small ferruginous concretions. Above the sandstone is gray and brown noncalcareous shale with concretions 2 feet or less in diameter.

An unusually instructive section showing the contact between the Indio and the Carrizo sand was observed on San Ambrosia Creek 200 yards below the mouth of Chupadero Creek. There the Carrizo, consisting of massive gray sandstone and shaly thin-bedded sandstone, overlies with an irregular contact the Indio, which consists of laminated or thin-bedded sandstone and shale with a dip of $5^{\circ}$ to $8^{\circ}(\mathrm{pl}$. $4, A){ }^{14}$ Trowbridge either did not see this section or considered the sandstone to be a part of the Indio. A similar section in Mexico a few miles south of the Chupadero ranch headquarters, on the Arroyo del Amole about a mile above its junction with the Rio Grande, has

13 Trowbridge, A. C., op. cit., p. 38.

13 Idem, p. 39.

4 Idem, p. 41 . 
been described by Baker. ${ }^{15}$ The unconformity is not evident in exposures along the Rio Grande between the mouth of San Ambrosia Creek and the old Sullivan ranch, which appear generally in a bluff 40 to 80 feet high consisting of Carrizo sand with poorly exposed shale and sandstone of the Indio at the base. The Sullivan Spring, Frijolita Springs (pl. 1), and other springs that are unnamed issue at the contact of the two formations.

Water supply.-The Indio formation does not furnish good water. Wells that are drilled to the thicker sand beds of the formation, as for example well 1 (see well tables and pl. 1), vield small amounts of water, which generally is salty but can be used for stock.

\section{CLAIBORNE GROUP}

\section{CARRIZO SAND}

Extent and character of outcrop.-The Carrizo sand crops out in the northwestern part of Webb County in a belt 2 to 3 miles wide extending from the Dimmit County line south to the Rio Grande (pl. 1), wholly within the Chupadero ranch. Much of the area is marked by a rolling topography, very sandy soil, and scattered trees and grass(pl. 6, B). The formation is unconformable on the underlying Indio formation and conformable below the Bigford member of the MountSelman.

Lithology.-The Carrizo sand consists almost entirely of sandstone but contains minor amounts of clay or shale. The sandstone is on the average coarser than that of any other formation in this area. It is generally light brown but locally medium brown, reddish, or light gray. Usually the sand is poorly cemented but with an appreciable amount of clay matrix. Locally it is cemented to quartzite or indurated sandstone, forming notable erosional features, as at Rocktown, southeast of the Chupadero ranch (pl. $5, A$ ). Cross-bedding is common but is restricted to small areas. In extended outcrops the formation appears to be massive with little or no evidence of bedding. Tbis is especially well shown in a bluff on the Mexican side of the Rio Grande (pl. 5, B). In places the lower part of the formation is thinbedded. Ferruginous sandstone occurs in beds a few inches thick, producing a ferruginous shingle. One such bed is near the lower contact of the formation west of the Chupadero ranch.

Clay or shale is present in the formation as thin lenticular beds. The road from the Chupadero ranch house to the Sullivan ranch house crosses an exposure of 6 to 8 feet of laminated gray sandy shale. The Juan Rey Spring (pl. 6, A) owes its origin to a lens of slightly carbonaceous shale about 6 feet thick in the Carrizo.

Laboratory tests and field observations show the sand and sandstone to be highly porous. Summaries of petrographic analyses of representative samples are given below.

15 Baker, C. L., quoted in Trowbridge, A. C., op. cit., p. 46. 


\section{Petrographic analysis of Carrizo sand from Juan Rey Spring}

Lithology and mineralogy.-A frisble light-gray massive sandstone, highly porous and practically lacking in cement. Has a slightly salt and pepper appearance under the microscope. Clear, pink, and brown quartz and chert constitute about 98 percent. Feldspar, mostly microcline, constitutes about 1 percent, and heavy minerals (garnet, zircon, ilmenite, tourmaline, and muscovite), a fraction of 1 percent.

Size and shape.-Grains characteristically angular and subangular, practically none rounded or subrounded. Mechanical analysis: 0.589 to 0.295 millimeter, 33 percent; 0.295 to $0.147,61$ percent; 0.147 to 0.074 , 3 percent; less than 0.074 , 3 percent.

Petrographic analysis of Carrizo sand 2 miles south of road from Chupadero ranch to Smith \& Woodward ranch, on creek flowing from Loza Tank

Lithology and mineralogy.-Argillaceous calcareous light-gray massive sandstone. Firmly cemented with irregular fracture. Clear, smoky, and rose quartz constitute about 97 percent, clay minera]s and calcite about 3 percent. Heavy minerals include zircon, tourmaline, pyrite, rutile, garnet, muscovite, and leucoxene.

Size and shape.-Grains characteristically angular and subangular, very few subrounded. Mechanical analysis: Larger than 1.65 millimeters, a fraction of 1 percent; 1.65 to 0.999 , a fraction of 1 percent; 0.999 to 0.589 , a fraction of 1 percent; 0.589 to $0.295,22$ percent; 0.295 to $0.147,68$ percent; 0.147 to 0.074 , 3 percent; less than $0.074,6$ percent.

Petrographic analysis of Carrizo sand near contact with Bigford member, half a mile northeast of road junction 1.3 miles east of Jardin windmill

Lithology and mineralogy.-Argillaceous light rusty-brown massive sandstone, highly porous and poorly cemented. Clear and rose quartz and chalcedony, 98 percent; feldspar (microcline and plagioclase) and clay pellets 2 percent. Heavy minerals include limonite, muscovite, and garnet.

Size and shape.-Grains characteristically angular and subangular. Mechanical analysis: 0.999 to 0.589 millimeter, 1 percent; 0.589 to 0.295 , 43 percent; 0.295 to $0.147,52$ percent; 0.147 to $0.074,2$ percent; less than $0.074,2$ percent.

In these samples 90 to 95 percent of the grains have sizes ranging from 0.147 to 0.589 millimeter. A very few large sand grains are found in most samples. Trowbridge ${ }^{16}$ gives the analyses of five samples of Carrizo sand on the Rio Grande at the Sullivan ranch house, which conform generally to the descriptions given above.

Thickness.-The thickness of the Carrizo sand is estimated to range from 125 to 250 feet. The width of the outcrop varies, and it is difficult to measure a complete section of the formation. The dip, estimated from well records, is 108 feet to the mile in the northern part of the outcrop area in this county. Near the Rio Grande, where the formation appears to have the least thickness, higher dips may occur, accounting for the thinner section.

Sections.-No complete section of the Carrizo sand is available. Exposures of the lower part of the formation are found along San Ambrosia Creek and have been mentioned in the discussion of the Indio formation. From the mouth of San Ambrosia Creek to the

16 Trowbridge, A. C., op. cit., p. 62. 
Sullivan ranch there is a cliff of the sandstone 40 feet high. Back from the cliff a few chimneylike or houselike hills of the sandstone stand 10 to 25 feet above the general surface. These are due to local cementation of the sandstone and reach their greatest development 2 miles southeast of the Chupadero ranch, at Rocktown. At the Juan Rey Spring about 35 feet of coarse white massive but slightly cross-bedded sandstone overlies a carbonaceous shale, which causes the spring to appear (pl. 6, $A$ ).

On the Mexican side of the Rio Grande 2 miles downstream from the Juan Rey Spring there is a rounded bluff of bare sandstone of similar character. The contact of the Carrizo sand with the Bigford member of the Mount Selman formation is exposed in a number of places, and sections showing the contact are given in the discussion of the Bigford member.

Water supply.-The Carrizo sand supplies water to shallow wells in the area of its outcrop and to deeper wells in a considerable area to the east of the outcrop. Wells $2,3,4$, and 5 (pl. 1 and well tables) are in the outcrop area. They are from 105 to 250 feet deep, and none of them are cased to the bottom. Wells 2 and 3 are said to have been drilled through the Carrizo sand into the Indio formation, but the table of analyses (p. 102) shows the water from well 2 to be of good quality. Apparently it is derived entirely from the Carrizo. The water from well 5 (analysis also shown in the table) contains a somewhat higher proportion of dissolved minerals than that from well 2 .

No exact data are available as to the yield of wells in the outcrop area of the Carrizo sand. All the wells are fitted with cylinder pumps and windmills, and the water levels in them are not appreciably lowered by this method of pumping. The similarity to conditions in other areas where the Carrizo sand is a source of water indicates that wells of fairly large yield can be obtained.

East of the outcrop area wells $6,7,10,11,13,14,15,17,18$, and 19 obtain water from the Carrizo sand. Wells 11 and 13 yield water of inferior quality but are reported to have once supplied better water. It is believed that these wells are contaminated with Bigford and higher Mount Selman waters because of insufficient or defective casings. Well 14 yields water that is comparatively fresh and soft. (See analysis, p. 102.) Wells 18 and 19 are new wells which are thought to penetrate the Carrizo sand. The water from these wells apparently is of good quality. Well 45 yields abundant water to the pump and was drilled through the Carrizo sand. The well is an abandoned oil test well, and the exact horizon from which the water is obtained is not known, because the casing was shot at several points. It is probable that the water is a mixture from several horizons.

The level to which water rises in the wells drilled to the Carrizo sand varies. The water levels in wells $2,3,4$, and 5 , all in the outcrop area, range from 58 to 67 feet below the surface. In the area east of the 


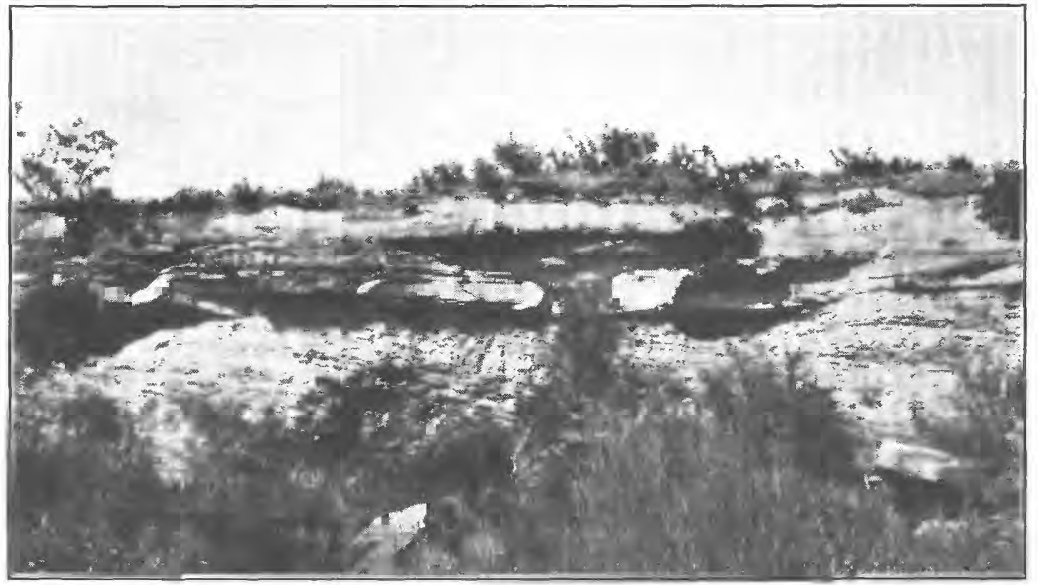

A. CONTACT OF INDIO FORMATION AND CARRIZO SAND AT MOUTH OF CHUPADERO CREEK.

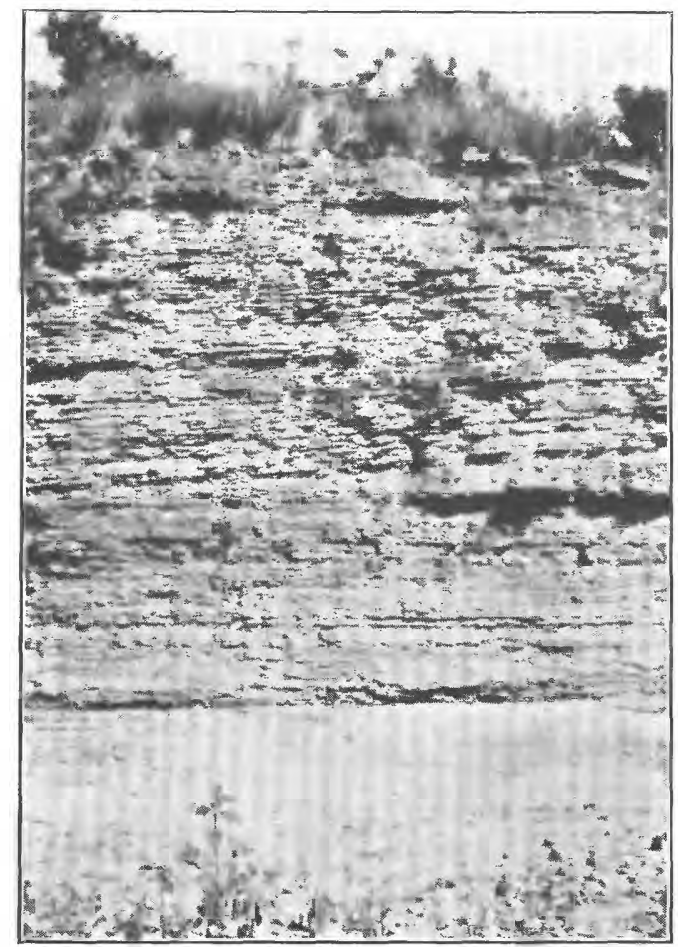

B. ALTERNATING SHALE AND SANDSTONE STRATA OF INDIO FORMATION ON BORREGO CREEK. 


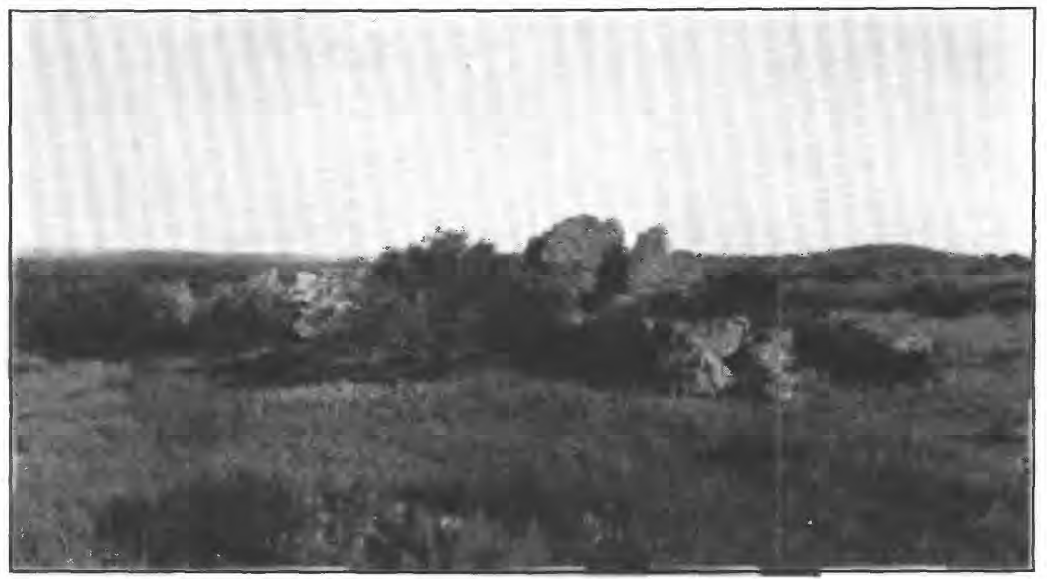

A. INDURATED SANDSTONE OF CARRIZO FORMATION AT ROCKTOWN, SOUTHEAST OF CHUPADERO RANCH.

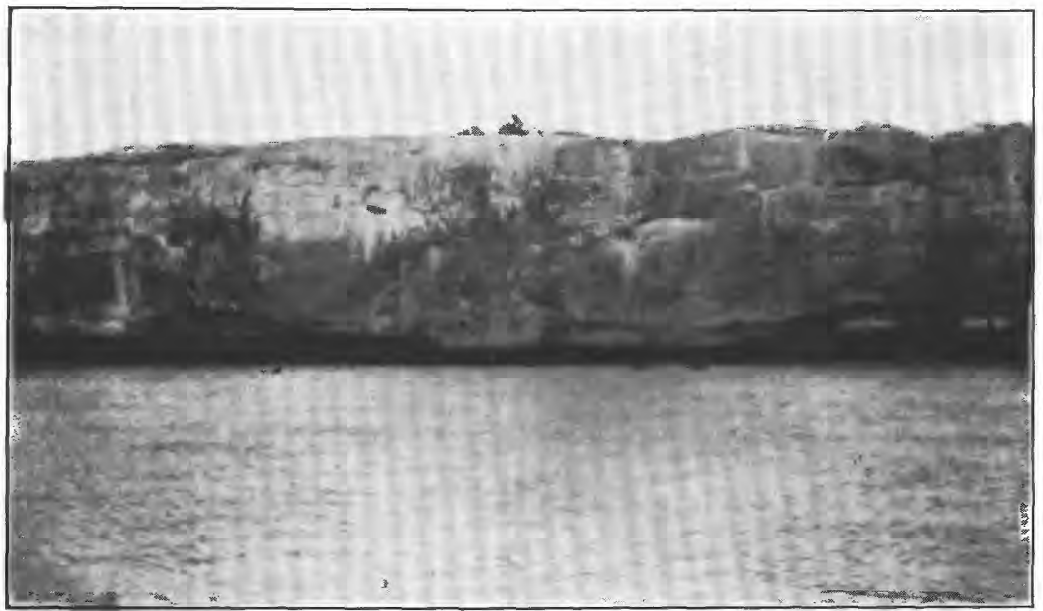

B. CARRIZO SAND ON MEXICAN SIDE OF RIO GRANDE SOUTH OF CHUPADERO RANCH. 


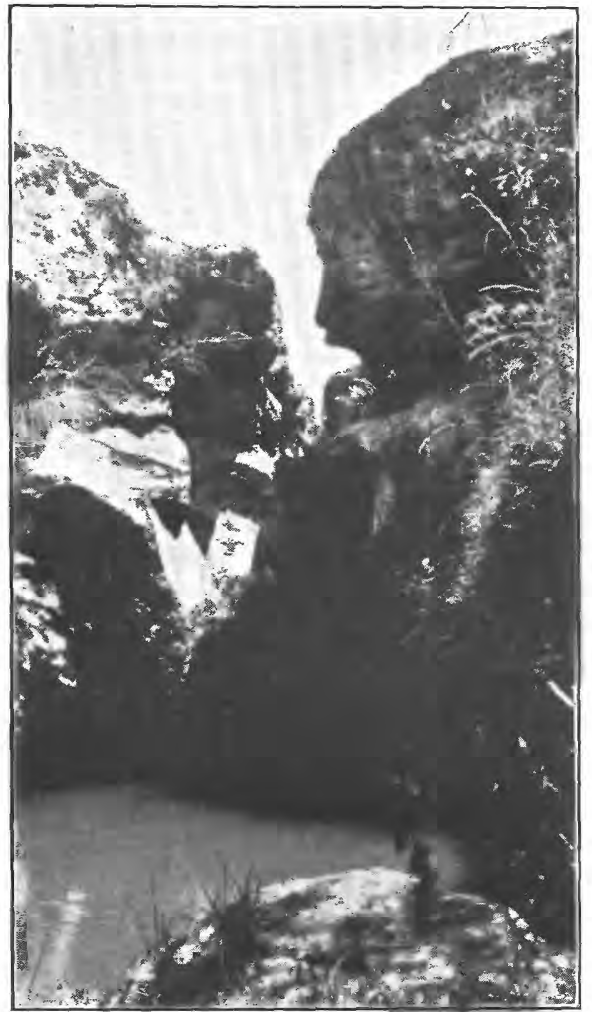

A. JUAN REY SPRING, CHUPADERO RANCH.

The spring is formed by a shale lens in the Carrizo sand.

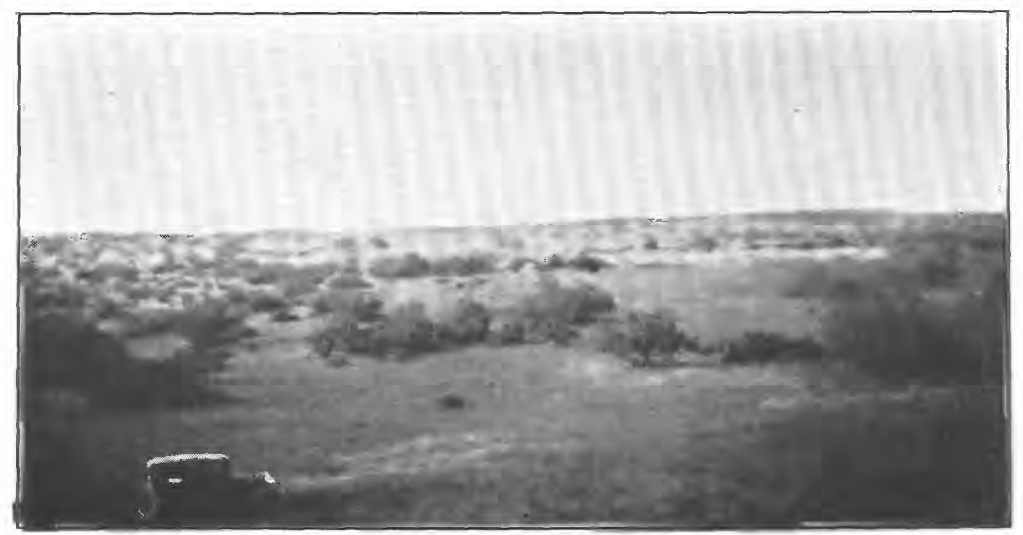

B. OPEN PRAIRIE COUNTRY CHARACTERISTIC OF OUTCROP OF CARRIZO SAND, CHUPADERO RANCH. 



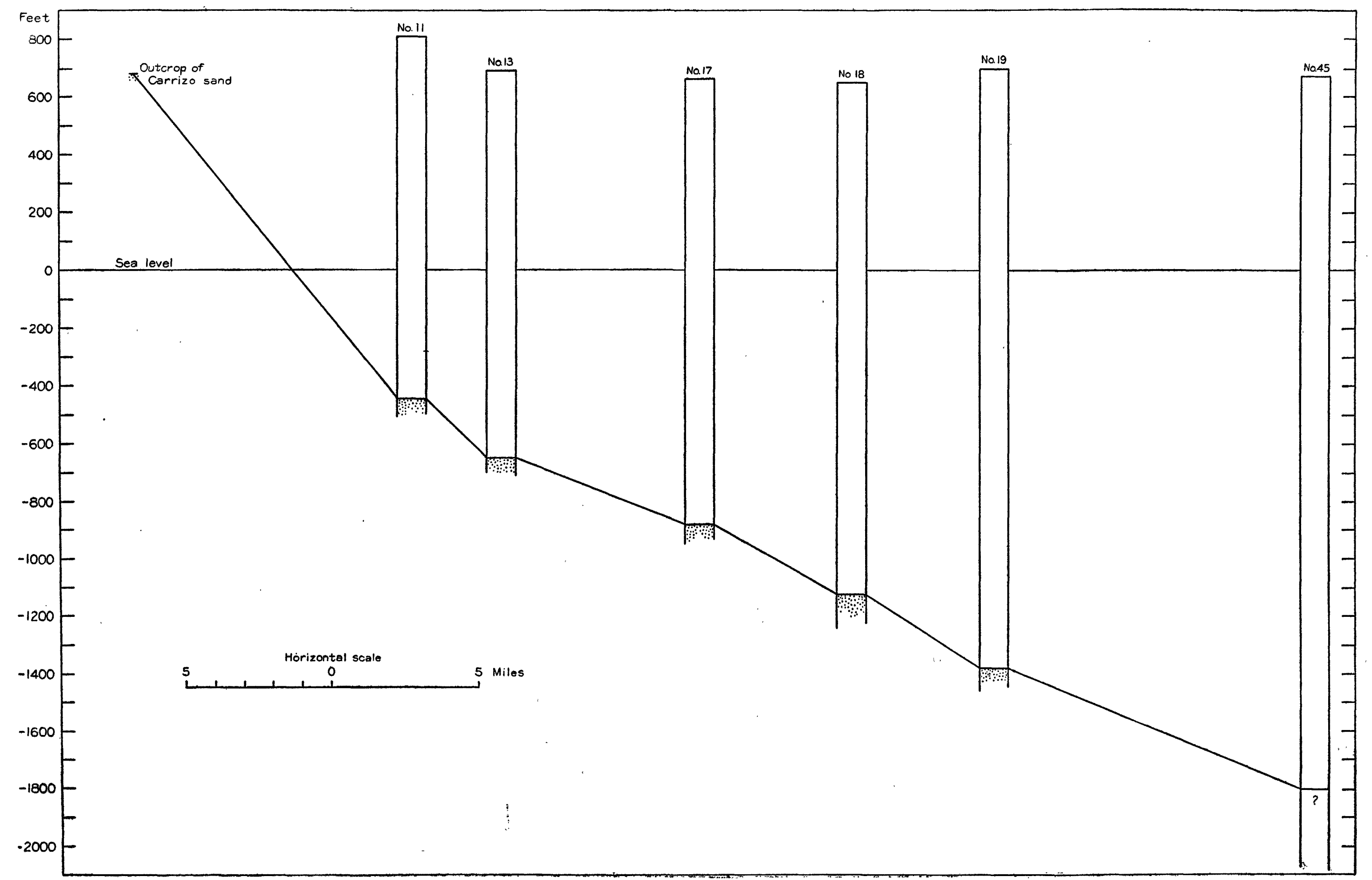

CORRELATION OF THE CARRIZO SAND IN TYPICAL WELLS IN NORTHWESTERN WEBB COUNTY, SHOWING DEPTH BELOW SEA LEVEL. 
outcrop most of the Carrizo wells are on the high land along the Nueces and Rio Grande divide, and the water levels are farther beneath the surface than in the outcrop area, reaching a depth of 270 feet in well 11. It is probable, however, that in the region near the Apache ranch wells drilled in the Carrizo either will flow or the water level in them will rise nearly to the surface.

In addition to the wells mentioned above several other wells that penetrate the Carrizo are listed in the table of well records. These are abandoned oil test wells, which, together with those mentioned, have been used to delineate the underground position of the formation. On plate 1 contours are drawn showing the depth to the Carrizo sand in part of the area of its outcrop. Unfortunately, insufficient wells are available to construct complete contours for all of the area beneath which the Carrizo may be found at depths that would justify drilling for water. The correlation of the Carrizo sand in some of the wells mentioned is shown on plate 7 . Plates 1 and 7 taken together can be used to guide drilling operations in the area east of the outcrop where the contours on the top of the Carrizo sand are shown. ${ }^{16 \mathrm{a}}$

\section{MOUNT SELMAN FORMATION}

During the last few years there has been considerable discussion and controversy regarding the correlation and nomenclature of the lower Eocene strata in southwestern Texas. Until recently the Carrizo sand and Bigford "formation", along with the Indio formation, were considered to be of Wilcox age and were so mapped and described by Trowbridge in his report of 1923. Subsequent to that time extensive work by petroleum geologists and geologists of the United States Geological Survey has led to the opinion that the Carrizo and Bigford strata are of Claiborne age. In his report of 1932 Trowbridge makes substantially the above statement, and the geologic map of Texas published in 1932 shows the Carrizo sand and Bigford "formation" as Claiborne.

The present work makes available additional evidence bearing on this matter. This includes a distinct angular unconformity between the Carrizo sand and Indio formation and collections of invertebrate fossils from the Bigford and Mount Selman. The fossiliferous zones were mostly discovered by the junior author and were traced in detail wherever exposed. They are shown on plate 1. The fossils were

\footnotetext{
16a The structural map of Texas (Texas Univ. Bull. 3401, pl. 1, 1936) can be used to supplement the con. tours shown on plate 1 of this report. The contours on the structural map of Texas show the depth below sea level of the top of the Carrizo sand in Webb County, based on oil test wells drilled since the completion of this work. The figures on the contour lines of that map should not be confused with those on plate 1 of this report, which show depths below the surface of the ground.
} 
examined by Julia A. Gardner and pronounced Claiborne in age. Her summary with regard to the collections follows:

The Bigford fauna of Webb County is clearly the ancestral fauna of the later imperfectly recorded Mount Selman fauna of the same area. It has very little in common, however, with that of the lower Mount Selman to the north and eastfor example, with the Reklaw of Gonzales and Bastrop Counties. Closer affinities may possibly be established with the faunas of northern Mexico, for the Webb County assemblages lived and were buried in an embayment isolated in some manner from that to the northeast but opening to the southeast across Nuevo Leon and Tamaulipas.

On the basis of the new evidence the strata below the Cook Mountain formation and above the Carrizo sand are classed as the Mount Selman formation, of Claiborne age. The formation is divided into the Bigford member, essentially the same as the Bigford "formation" of Trowbridge, and the post-Bigford beds, essentially the same as the Mount Selman of Trowbridge.

BIGFORD MEMBER

Areal extent.-The Bigford member of the Mount Selman formation crops out in the western part of Webb County in a belt with a maximum width of $7 \frac{1}{2}$ miles. It is exposed along the Rio Grande from a point south and slightly east of the Chupadero ranch to a point near Dolores, where it passes across the river (pl. 1). The greater part of the outcrop area is comparatively rough and broken, with dense growths of chaparral. Numerous exposures are found in the many ravines and gullies. The contact of the Bigford member with the Carrizo sand is exposed along the hills east and south of the Loza tank, 5 miles southeast of the Chupadero ranch, and is conformable, with a gradation from the coarser sandstone of the Carrizo to the clayey sandstone and clay of the Bigford. The contact of the Bigford member with the overlying beds of the Mount Selman formation is an arbitrary line located at that point in the section where the more sandy Bigford strata change to those of a more argillaceous nature. This contact in the area west of the Pilotes ranch is essentially that of Trowbridge. ${ }^{17}$ The actual line of contact is drawn on a thin fossiliferous sandstone stratum 16 feet above a coal bed exposed at the prospect west of the Pilotes ranch. This fossiliferous bed or its equivalent has been traced in detail for several miles to the north of the coal prospect, and southeast of it to the point where the bed crosses the Rio Grande near Dolores. A comparison of plate 1 and the geologic map accompanying the report by Trowbridge shows that the present work includes in the Bigford member, in the region near Palafox, sandstone beds classed as Mount Selman by Trowbridge. The detailed mapping carried on in the present investigation also results in the placing of the San Pedro coal in the Bigford member and the Santos Tomas coal in the overlying beds of the Mount Selman.

17 Trowbridge, A. C., op. cit., pl. 7. 
Lithology and paleontology.-The Bigford member is composed of dark-brown to buff and gray gypsiferous clay, thin-bedded to massive varicolored sandstone, concretionary limestone, lignite, and cannel coal. Sandstone makes up about 25 percent of the member but occurs in relatively prominent escarpments, so that it appears to be present in greater amounts than is actually the case. The sandstone is generally fine-grained and exhibits a considerable range in color, including pastel shades of pink and purple. Most of it is argillaceous and of relatively low porosity. Individual beds reach a maximum of 40 feet in thickness. Cross-bedding is not common. Several of the fine-grained sandstones contain remains of invertebrates or plants. Eight fossil zones have been mapped, two of which are traceable across the county.

Eleven coal beds more than 6 inches thick in this member have been mapped. The thickest bed is the San Pedro, which has a maximum thickness of 2 feet. Both cannel coal and lignite are found in this bed. The cannel coal has been mined at Dolores and nearby places.

The outcrop of the San Pedro bed is shown on plate 1 . In the mines at Dolores and nearby this bed is 60 feet below the fossiliferous stratum at the top of the Bigford member. It is not a continuous bed of cannel coal, and the interval between it and the top of the Bigford is not constant. In places, instead of one bed of cannel coal, several thin beds of lignite occupy the general zone of the San Pedro bed. At a coal prospect west of the Pilotes ranch a bed of cannel coal occurs 16 feet below the fossiliferous bed. At the old crossing of Espada Creek, 3 miles south of the coal prospect, a coal bed crops out 41 feet below the fossiliferous stratum. It seems best, therefore, to regard a zone 16 to 60 feet below the top of the Bigford member as the San Pedro zone. The fossiliferous stratum has been traced throughout the area and is a reliable reference bed.

Much of the clay in the Bigford is sandy, but some of the beds are nearly pure clay, usually gypsiferous. The clay and sandy clay do not show the laminated character so pronounced in the Indio formation. The limestone is gray or yellow and concretionary. Individual beds rarely reach 1 foot in thickness. Below are given petrographic analyses of sandstones representative of the range shown in the member.

Petrographic analysis of Bigford sandstone 5 miles southeast of Chupadero ranch, near road to Smith \& Woodward ranch

Lithology and mineralogy. - A very fine buff argillaceous sandstone with abundant small plant fragments. Minerals are quartz, clay minerals, zircon, apatite, glauconite (?), rutile, tourmaline, plagioclase, biotite, chlorite, and muscovite.

Size and shape.-Grains characteristically angular to subangular. Mechanical analysis: 0.147 to 0.295 millimeter, a fraction of 1 percent; 0.074 to $0.147,4$ per- 
cent; smaller than $0.074,94$ percent. Another sample from the same locality shows percentages as follows: 0.074 to 0.147 millimeter, 2 percent; smaller than $0.074,98$ percent.

Petrographic analysis of Bigford sandstone 0.4 mile northwest of Loza tank, ChupaderoRanch

Lithology and mineralogy.-Fine-grained massive buff sandstone. Quartz constitutes about 99 percent, plagioclase and heavy minerals about 1 percent. Heavy minerals include zircon, rutile, tourmaline, leucoxene, magnetite, ilmenite, and apatite.

Size and shape.-Grains characteristically angular to subangular. Mechanical analysis: 0.147 to 0.295 millimeter, a fraction of 1 percent; 0.074 to $0.147,8$ percent; smaller than $0.074,91$ percent.

Petrographic analysis of Bigford sandstone half a mile south of Loza tank, Chupadero ranch, on east-west fence

Lithology and mineralogy.-Medium- to fine-grained soft argillaceous light yellowish-gray sandstone, with minute white flakes scattered throughout. A few small elongated clay nodules are present. Gray and smoky quartz constitute about 98 percent; plagioclase, microcline, and clay minerals about 2 percent. Heavy minerals include tourmaline, zircon, apatite, rutile, muscovite, biotite, and garnet.

Size and shape.-Grains characteristically subangular and subrounded, with a few rounded grains. Mechanical analysis: 0.147 to 0.295 millimeter, 65 percent; 0.074 to $0.147,21$ percent; less than $0.074,14$ percent.

Petrographic analysis of Bigford sandstone on bluff $3 \frac{1}{2}$ miles south of Tordillo windmill and 1.3 miles southeast of northwest corner of lower Tordillo pasture

Lithology and mineralogy.-Fine-grained compact gray sandstone with irregular brown laminations. Quartz constitutes about 98 percent, plagioclase about 2 percent. Heavy minerals include rutile, zircon, ilmenite, magnetite, leucoxene, and tourmaline.

Size and shape.-Grains characteristically angular and subangular, a few subrounded. Mechanical analysis: 0.295 to 0.589 millimeter, 1 percent; 0.147 to $0.295,3$ percent; 0.074 to $0.147,41$ percent; smaller than $0.074,55$ percent.

Petrographic analysis of Bigford sandstone 0.75 mile north of Guajalote windmill and 6 miles south of Chupadero ranch house

Lithology and mineralogy.-Fine-grained buff to purplish argillaceous sandstone with low porosity. Quartz constitutes about 96 percent, clay minerals 3 percent, plagioclase and microcline 1 percent. Heavy minerals include pyrite, zircon, tourmaline, muscovite, rutile, and apatite (?).

Size and shape.-Grains characteristically angular and subangular, a few subrounded. Mechanical analysis: 0.147 to 0.295 millimeter, a fraction of 1 percent; 0.074 to $0.147,36$ percent; smaller than $0.074,63$ percent.

Thickness and dip.-The thickness of the Bigford member in a composite section measured along the Rio Grande is 660 feet. The dip as observed at the surface is variable. A number of minor folds 
have caused dips as high as $45^{\circ}$. It is probable that the regional dip is about 120 feet to the mile.

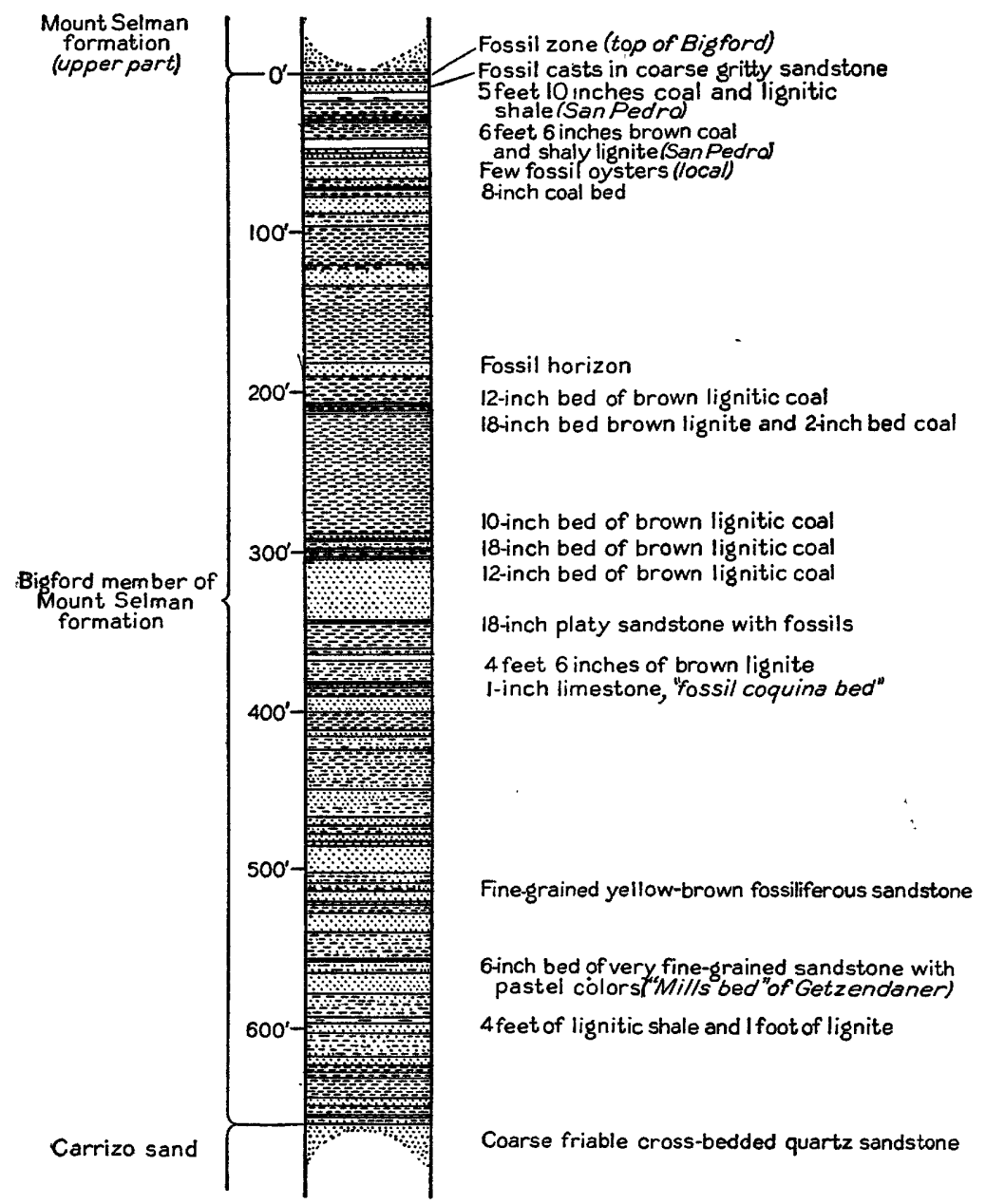

Figure 2.-Composite section of Bigford member of Mount Selman formation showing fossil horizons and coal beds.

Sections.-A composite section of the Bigford member from exposures near the Rio Grande is given below and is shown graphically in figure 2. 


\section{Composite section of Bigford member in northern Webb County}

Thin-bedded fine-grained gray sandstone interbedded with gray sandy shale and shaly sand. At top, hard finegrained layer about half an inch thick and fossiliferous_

Ledge of massive, very irregular pinkish and purplish-gray fine-grained banded and pitted sandstone, locally fossiliferous

Ft. in.

Thin beds of gray fine-grained sandstone with alternate beds of soft purplish shaly sand

Soft purplish shaly sand with yellow streaks

Finely laminated thin-bedded fine-grained purplish-black hard lignitic shale; weathers gray white.

Coal and lignitic shale (Upper San Pedro coal)

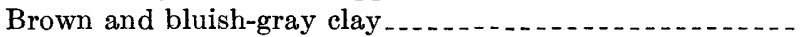

Layers of limonite and gray sandy shale .............

Light-brown mealy-textured, slightly gritty iron-stained and coated ledge of sandstone, locally fossiliferous ....

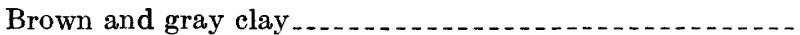

Light-brown and some blackish-brown lignite (Lower San Pedro coal)

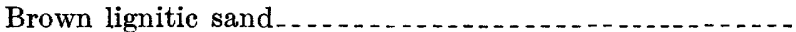

Soft massive, jointed sandstone, weathering buff-gray ....

Greenish-gray and brown clay

Ledge of buff-gray fine-grained sandstone in massive beds 2 inehes to 1 foot thick, finely laminated, with carbonaceous material between laminae, micaceous.......

Yellow-greenish shaly sandstone and shale grading down into irregular yellow-streaked buff-gray clay .........

Black lignitic coal

Blackish and gray-brown clay . . . . . . . . . . .

Ledges of fairly hard fine-grained irregularly laminated gray sandstone.

Rusty-brown and gritty gray and brown sandstone.......

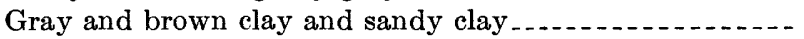

Gray and brown gypsiferous clay ........................

Gray and brown clay

Soft mealy-textured gray sandstone yellow silty and limy boulders 1 foot thick at top......-

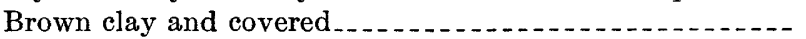

Soft brown and gray shale and clay .................

Sticky and crumbly gray-brown clay ..................

Purplish-gray elay ... . . . . . . . . . . . .

Hard massive bed of purplish-gray and brown sandstone, locally fossiliferous...........

Soft poorly bedded fine-grained gray sand with lignitic streaks and plant roots; fossils at top................

Very soft gray and brown sand.........

Purplish-brown and gray gypsiferous elay .............. 18

Bedded brown lignite....... 1

Brown clay ........... 2

Dark-brown lignite; about 2 inches of coal $\ldots$

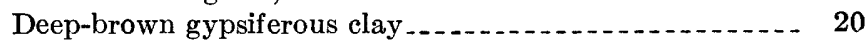


Composite section of Bigford member in northern Webb County-Continued

Ft. in.

Flat of brown gypsiferous clay and other soft material, about

Soft brown sand.... 3

Brown lignite...-.

Soft shaly lignitic purplish sandstone...............

Shaly gray thin-bedded sandstone.

Lignite

Brown sandy shale and clay

Brown lignite. ..............

Soft gray cross-bedded sandstone and sandy series.......

Light-yellow and grayish-brown, very thin-bedded hard platy fossiliferous sandstone

Brown gypsiferous clay

Gray and yellow shale and sand

Lignite.

Soft brown and gray sand, shale, and clay

Fossil coquina at south and fossiliferous sandstone bed at north under associated yellow concretionary limestone bed.

Poorly bedded soft crumbly sand

Brown and oray gypsiferous clay and some lignite

Soft medium-grained gray sand

Brown gypsiferous clay and purplish-gray and brown

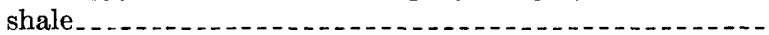

Thin ripple-marked beds of gray distorted hard fossiliferous sandstone.

Gray and yellow mottled massive sandstone.........

Gray and yellow-brown shale and shaly sandstone and limonite.

Flat; probably clay and shale and soft sand ...........

Purplish and brown thin-bedded medium-grained sandstone with alternate gray and brown shale.

Harder thin-bedded medium-grained sandstone with limonite.

Purple, gray, and yellow thin-bedded sand and shale with alternate clay and limonite laminae.

Soft gray bedded fine-grained sandstone

Very hard massive yellow ledge of concretionary limestone.

Very hard quartzitic blue-gray sandstone ledge; broad beds with irregular purple streaks.

Gray and yellow mottled fine-grained sof $t$ sandstone

Soft, rather massive medium-grained brown sandstone...

Shaly brown and gray sand and clay

Thin-bedded gray sandstone and associated yellow concretionary limestone.

Rusty-brown and purplish iron concretionary bed......

Thin beds of brownish-gray fossiliferous sandstone.......

Thin-bedded gray and yellow-brown laminated sandstone.

Yellow cone-in-cone and concretionary limestone bed....

Gray-brown clay

Concretionary iron bed over fairly thin beds of crumbly grayish and yellowish-brown sandstone 
Composite section of Bigford member in northern Webb county-Continued

Brown sandy clay

Hard ledge of medium-grained micaceous banded sandstone

17

Purple and gray shaly sand...

Purplish and gray fairly soft fine-grained sandstone.......

Very thin bedded gray and brown fine-grained sandstone.

Gray, brown, and yellow shaly sand, shale, and limonite.-

Gray sandy clay

Gray sandy clay sandstone boulders . . . . . . . . . . . 1

Local lignitic shale and lignite._... 5

Gray thin-bedded sandstone........................ 1

Coarse-grained crystalline, poorly bedded sandstone ledges. $\quad 7$

Thin beds of sand and shale with limonite... ......... 15

Ledge of hard fine-grained iron-stained gray sandstone... 1

Alternating beds of thin yellow and gray sands.......... 6

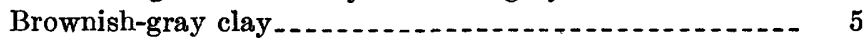

Brownish sandy clay and clayey sand............... 4

Alternating beds of gray shale and clay ........... 12

Thin beds of soft buff to gray and yellow-brown finegrained micaceous sandstone having poorly preserved leaf imprints; clay flakes between the massive beds....Gray-brown sticky clay . . Dark-brown friable coarse-grained standstone. .......... Fine-grained gray shaly sand, platy gray shale. and limonite

Detailed sections from various localities are given below. The first section is at the contact of the Carrizo sand and the Bigford member.

Section of Carrizo sand and Bigford member 0.8 mile south of Loza tank, Chupadero ranch, northern Webb County

Bigford member of Mount Selman formation:

Purple, gray, and brown medium-grained sandstone......-

Thin-bedded gray and brown sandstone...............

Covered...... 11

Gray sandy clay

Hard fine-grained dark-gray calcareous sandstone boulder _ 1

Covered_... _.

Fine-grained gray sandstone ledge

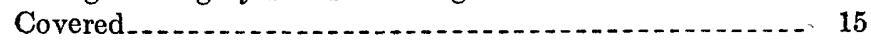

Shale and sandstone

Alternating beds of shale and sandstone.............. 12

Covered._.

Thin-bedded medium-grained gray sandstone with leaf imprints.............. 8

Dark-brown coarse-grained friable sandstone............ 1

Gray argillaceous sandstone........... 3

Carrizo sand: Very coarse friable yellow-brown and white poorly bedded to massive sandstone. 
This section illustrates the gradation from the Carrizo sand to the Bigford member. Another section showing the same features, at a locality closer to the Rio Grande, is given below.

Section of Carrizo sand and Bigford member on west flank of hill 0.9 mile north of Juan Rey Spring, Chupadero ranch

Uvalde gravel (cap of hill) $\quad \begin{array}{r}\text { Feet } \\ 25\end{array}$

Bigford member of Mount Selman formation:

Soft yellow and gray mottled fine-grained sandstone _.... 2

Platy fine-grained gray sandstone................ 7

Gray and brown shale and clay

Brown and gray shaly sandstone $\ldots \ldots \ldots$

Soft thin-bedded fine-grained sandstone with leaf imprints and clay nodules...... 5

Grayish-brown sticky clay _...

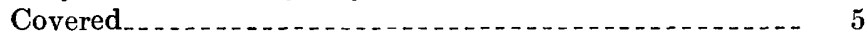

Platy gray sandstone, gray paper shale and limonite ..... 4

Concretionary fine-grained gray sandstone with limonitic

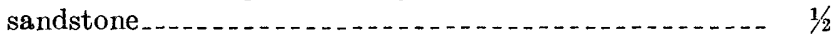

Carrizo sand:

Cross-bedded and poorly bedded gray medium-grained poorly cemented iron-stained sandstone.............

Poorly bedded and cross-bedded gray and yellowish-brown coarse-grained sandstone . . . . . . . . . . . . . . . . . . .... 11

Dark-brown iron-stained coarse-grained friable sandstone_ 5

Coarse-grained yellowish-brown, brown, and gray poorly bedded friable sandstone........................ 18

Zone of sandstone boulders. . . . . . . . . . . . . . . . . . 4

Coarse-grained poorly cemented gray sandstone $\ldots . . . . . . . .8$

Section of Bigford member on east bank of Rio Grande at Bigford (Cuatralvo) ranch

[Dip $\left.1^{\circ}\right]$

Soft gray cross-laminated fine-grained sandstone

Feet

Greenish-gray and yellowish-brown clay and thin-bedded shaly sandstone

Hard massive iron-stained sandstone with worm borings......

Soft yellow-brown and gray laminated shaly sandstone.......

Gray and brown iron-stained sandstone . . . . . . . . .

Beds of grayish-brown laminated fine-grained sandstone 6 inches thick

Thin-bedded hard and soft laminated yellowish-brown shaly sandstone

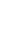
8

Yellowish-gray and brown iron-stained shale and clay

Medium-grained finely laminated hard gray sandstone......

Soft gray and brown fine-grained sandstone.....

The section given above was measured at the type locality of the Bigford member. Trowbridge ${ }^{18}$ has described a section from the same general locality. The large proportion of sandstone in the section is notable. The clay or shale strata of the Bigford do not form

18 Trowbridge, A. C., op. cit. (Bull. 837), p. 74.

$105575-37-3$ 
good exposures but are usually covered in slopes. In the first deep ravine southeast of the Bigford ranch a section of typical clay is exposed, as shown below.

Section of Bigford member in arroyo 0.8 mile east of Bigford ranch, 250 yards above mouth

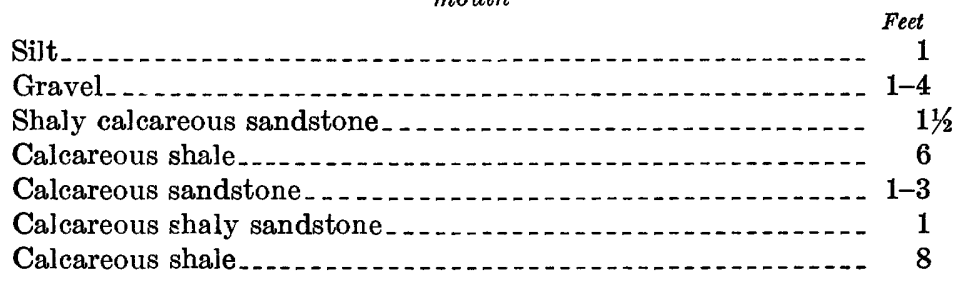

In this section the shale is bluish gray when fresh but weathers to a dark greenish gray. The weathering produces nodular lumps as much as 4 inches in diameter, and this seems to be characteristic of much of the clay or shale of the member. In this section a few plant impressions are present along with a small amount of lignitic material.

Excellent sections of the lower Bigford strata are exposed in San Lorenzo Creek. One of the sections is given below.

\section{Section of Bigford member 1 mile upstream from mouth of San Lorenzo Creek}

Reddish to brownish and buff fine micaceous sandstone.

Ft. in.

Bottom 4 feet thin-bedded, platy. Upper 2 feet thinbedded, brown. Center 4 feet massive, with beds 2 feet 6 inches or less in thickness. A line of ferruginous calcareous concretions near center.

Chocolate-brown sandy shale, weathering light gray and grading into beds above

Sandstone consisting of three members, upper 2 feet 10 inches, middle 7 inches, bottom 3 feet 9 inches. Upper and lower members fine-grained, purplish when fresh, yellowish buff on weathering, minute lignite streaks, micaceous, and with plant remains and fucoidlike markings, jointed into rectangular blocks; selenite on joint planes.

T. in.

Chocolate-brown micaceous sandy shale, with line of calcareous concretions at base.

Sandy platy argillaceous sandstone; grades into underlying beds; plant remains on bedding planes; weathers light gray; noncalcareous.

Dark-gray to black shale showing many bedding planes, usually outlined with yellowish stain and about 2 inches apart; weathers buff to gray, often with white salt efflorescence; noncalcareous . . . . . . . . . . . . . . . . . . . . . .

Bottom of creek; massive light-gray fine-grained sandstone with a few shelly reddish to purplish indurated layers 2 inches or less in thickness; noncalcareous. ..........

At 150 feet above the base of the Bigford there is a thin fossil zone that is prominent near the Rio Grande in the southern part of the 
Chupadero ranch. Below this zone is an alternating succession of thin beds of shale, clay, fine-grained sandstone, and all gradations between sand and clay. Limonitic shingle is very prominent, and the weathered slopes of most of the hills in this belt are yellowish to red. The lowest cannel coal in the Bigford occurs in the lower part of these strata, about 65 feet above the base of the member. The following section is typical of this portion of the Bigford:

Section of lower part of Bigford member on east bank of Rio Grande 11/2 miles north of the mouth of San Lorenzo Creek

Very hard gray sandstone which forms a ledge..........

Massive single hard ledge of yellow concretionary limestone.

Ft. in.

2

Brown clay and shaly brown sand

Brown and purplish concretionary iron beds........

Brown clay and thin brown fossiliferous sandstone.......

Yellow cone-in-cone and concretionary limestone bed...-

Brown sticky clay -. . . . . . . . .

Dark coarse-grained sandstone and deep-brown concretion-

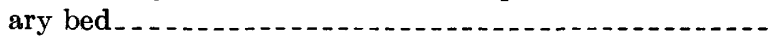

Purplish gypsiferous shale and brown sandy shale.........

Hard brown coarse-bedded sandstone..............-

Soft fine-grained brown, gray, and lavender sandstone in beds 3 to 6 inches thick separated by gypsum laminae which give it a banded appearance......................

Gray and yellow-brown, poorly bedded and thin-bedded

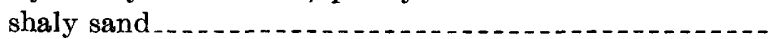

Lavender shale and yellow sandy shale with gypsum laminae ... . .

Yellow-brown and gray, partly laminated sandstone.....

Jointed gray, slightly bedded fine-grained sandstone......

Fine-grained yellow-mottled thin-bedded to massive sandstone ledge . . . . .

Lavender shale with yellow and brown shaly sand

Yellow-gray jointed soft shaly sandstone $\ldots . . . \ldots \ldots \ldots$

Brown lignitic sand........

Black jointed cannel coal

Yellow-brown shaly lignite.

Hard yellow-gray massive sandstone ledge

Brown and gray sandy shale......... 1

Yellow, brown, and gray mottled massive sandstone..... 2

Gray and yellow-brown shaly sandstone and sand....... 12

The middle and upper Bigford strata are characterized by more true clay, smaller amounts of sandy clay and limonitic material, and more thin coal beds. The following section just above the middle of the Bigford illustrates these characteristics. Views of Bigford strata from this locality are shown on plate 8 . 
Section of middle part of Bigford member at mouth of San Cirile Creek, at Rio Grande, 3 miles north of Old Apache ranch

Soft brown clay with some layers of dark-brown flaggy fossiliferous sandstone 1 inch thick

Ft. in.

Hard fine-grained light bluish-gray massive sandstone

Two hard layers of yellow-brown and gray mottled finegrained massive sandstone with root and stem imprints.

Thick beds of partly cross-bedded massive fine-grained bluish-gray micaceous sandstone ...............

Slightly irregular fine-grained micaceous sandstone, weathering yellow-brown and purplish banded brown..

Dirty-brown and dull gray-brown soft fine-grained sandstone.

Laminated and shaly brown and gray mottled clay

Hard ledge of very fine-grained laminated yellowish and blue-gray sandstone.

Thin beds composing a ledge of very fine-grained finely laminated yellow and bluish-gray sandstone........

Shaly gray sandstone, shale, and gray limonitic clay ..... Soft massive buff-gray fine-grained sand.............

Blue and greenish-gray laminated and jointed gypsiferous clay

Yellow and brown flaky and shaly jointed lignite.......

Smutty brownish-gray lignitic fine-grained massive sandstone

Hard ledge of yellow-brown and gray banded fine-grained, massive sandstone

Brown and greenish-brown gypsiferous clay

Black and brown clayey lignite......................

Medium-hard yellow-brown massive medium-grained, slightly friable and partly laminated sandstone........

Gray-brown and yellowish lignite, clay, and shale........

Yellow and rusty-brown lignite, jointed and slightly shaly, with gypsum and yellow powder in joints and between laminae.

Gray flaky shale

Laminated and jointed layers of gray and brown shale and sandstone with gypsum layers.........................

Soft massive, slightly mealy-textured dull-yellow and brownish-gray sandstone.

Gray and brown mottled gypsiferous clay

Green and gray clay and sandy shale, with layers of yellow ferruginous silty sand.

Dark-blue and blackish-gray clay

Greenish and blue-gray clay.

Soft yellow and greenish-gray massive sandstone in beds 2 inches to 1 foot thick, some partly laminated

The following two sections are typical of the upper Bigford. The first gives the fossil zone at the top of the Bigford and the highest coal in the San Pedro zone underneath it. The second gives the fossil zone at the top of the Bigford, a fossil zone just below the top, and the upper and lower coal and goes down almost to a prominent sandstone in the upper Bigford, shown in figure 2. 
Section at coal prospect 3 miles west of Pilotes ranch

- Shaly gray sandstone and shale; top hard, fine-grained

0.5 inch fossiliferous

Ft. in.

Massive pinkish and purplish fine-grained banded and pitted sandstone

Thin beds of gray fine-grained sandstone alternating with soft purplish clay

Soft purplish shale with yellow streaks.

Fine laminated thin-bedded purplish-black lignitic shale_.

Black cannel coal

Brownish soft coal

Impure lignite

Reddish mottled gray and brown joint clay

(ction of Mount Selman formation on south bluff on large creek 1.4 miles northwest of San Pedro Hill

Ledge of irregular massive pinkish-brown medium-grained gritty, partly iron-stained sandstone

Ft. in.

(1)

Beds of fine-grained purple, gray, and brown banded sandstone 2 to 6 inches thick

Soft thin-bedded sand and shale, partly covered......... Bigford member:

Thin flaggy yellow-gray fossiliferous sandstone......

Ledge of mealy gray and brown white-speckled sandstone with a few hard round boulders ............

Thin-bedded fine-grained purplish-gray and brown sandstone

Thin-bedded and shaly brown sandstone with limonite

Fine-grained purplish-gray and brown mottled, yellowstained fossiliferous sandstone

Purplish-gray, brown, and yellow mottled massive finegrained irregular wavy-banded sandstone

Thin-bedded micaceous gray-white sandy shale and sandstone.

Lignite and cannel coal (Upper San Pedro coal) .....

Purplish and gray clay

Thin-bedded platy iron-stained gritty brown sandstone

Hard massive gray-white fine-grained irregular sandstone in thin beds.

Blackish lignitic clay

Brown and gray clay

Gritty, glistening irregular gray and brown sandstone ledge, limonite-coated

Brown clay . . . . . . . . .

Dark-purplish and yellow-brown limonitic concretions

Soft buff, gray, and yellow-gray fine-grained thinbedded sandstone.

Lignite (Lower San Pedro coal) 
Many additional sections could be given, but the general character of the Bigford member is shown in the sections presented above. The fossil horizons and coal beds are accurately located on plate 1.

Water supply. - The Bigford member in Webb County is not known to yield water that is suitable for domestic use or irrigation. Well 9 and probably well 16 (see table of water analyses, p. 102) derive water from the member, and the water from both wells is too salty for any use except stock. As noted in the discussion of the water supply of the Carrizo sand, wells that pass through the Bigford into the Carrizo and are improperly cased eventually become contaminated with salt water.

The Carrizo sand is the logical source of water in the outcrop area of the Bigford. It can be reached by wells at depths ranging from a few feet in the western part of the area to somewhat less than 1,000 feet in the eastern part. From plates 1 and 7 the depth to the Carrizo in any part of the area can be approximately determined.

\section{POST-BIGFORD BEDS}

Areal extent.-The post-Bigford part of the Mount Selman formation (see p. 20) crops out in a belt from 9 to 23 miles wide in centralwestern Webb County (pl. 1). Good exposures are found in the breaks of the Rio Grande, but north of the breaks exposures are not abundant. The upper boundary of the formation shown on plate 1 is essentially the same as that of Trowbridge. ${ }^{19}$ It is placed in that part of the section where the strata become more sandy and more fossiliferous.

The outcrop area of the post-Bigford part of the Mount Selman is characterized by a gently rolling topography with sparse vegetation except on gravel-covered hills. Scattered cuestas and isolated prominent hills are formed by hard sandstone beds, of which a hill half a mile south of the Pilotes ranch is an example. This landmark is shown on plate $9, A$.

Lithology.-The post-Bigford part of the Mount Selman formation consists of yellow, brown, gray, and dark-gray clay, varicolored sandstone, concretionary limestone, lignite, and cannel coal. Much of the clay is gypsiferous and contains rare concretions of barite. In a composite section of this part of the formation sandstone beds make up 10 percent of the total thickness, but a good many of the clay beds are somewhat sandy. There are seven coal beds 6 inches or more thick, but of these the Santo Tomas coal is the only one of commercial importance. Three fossil zones have been mapped and are shown on plate 1. They are not as persistent as those of the Bigford member. The position of the coal and fossil zones in the section is shown in figure 3 .

19 Trowbridge, A. C., op. cit. (Bull. 837), pl. 7. 


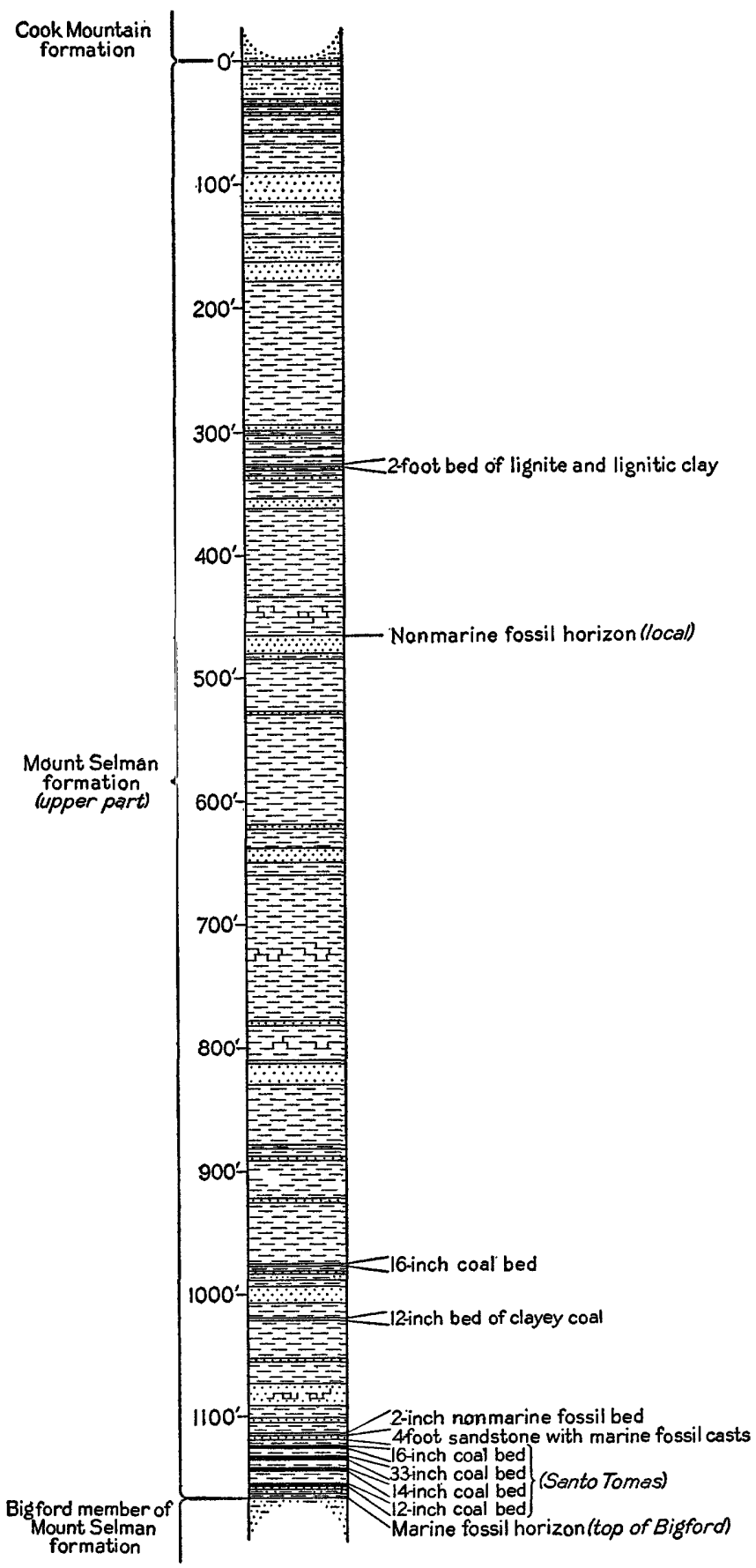

FIGURE 3.-Composite columnar section of upper part of Mount Selman formation showing fossil zones and coal beds. 
The Santo Tomas coal is cannel coal and is mined at Dolores. At this place the coal bed is 90 feet above the San Pedro coal and 30 feet above the fossiliferous stratum at the top of the Bigford. North of the Dolores area the Santo Tomas bed is traceable into four or five thinner beds which are lignite in some places and cannel coal in others. It is probably preferable to speak of the Santo Tomas zone rather than the Santo Tomas coal bed except in the area near Dolores. Sections given farther on illustrate this point. An exposure of the Santo Tomas and associated coal beds is shown on plate $9, B$.

Petrographic analyses of the sandstones, selected to show the range in texture, are given below.

\section{Petrographic analysis of post-Bigford sandstone from hill 1.3 miles east of Tordillo ranch}

Lithology and mineralogy.-Buff argillaceous sandstone with irregular reddish mottling, poorly cemented, low porosity. Quartz constitutes 97 percent, clay minerals and plagioclase 3 percent. Heavy minerals include magnesite, ilmenite, leucoxene, rutile, zircon, tourmaline, and muscovite.

Size and shape.-Grains characteristically angular and subangular, a few subrounded. Mechanical analysis: 0.147 to 0.295 millimeter, 2 percent; 0.074 to 0.147, 64 percent; smaller than $0.074,34$ percent.

Petrographic analysis of post-Bigford sandstone 0.3 mile south of Wayne ranch

Lithology and mineralogy.-Argillaceous massive brownish sandstone. Poorly cemented, of medium porosity, with irregular fracture. Iron-stained quartz constitutes about 97 percent, clay minerals about 3 percent. Heavy minerals include zircon, tourmaline, leucoxene, ilmenite, magnetite, rutile, and garnet.

Size and shape.-Grains characteristically subangular to subrounded. Mechanical analysis: 0.295 to 0.589 millimeter, a fraction of 1 percent; 0.147 to $0.295,85$ percent; 0.074 to $0.147,9$ percent; smaller than $0.074,4$ percent.

Petrographic analysis of post-Bigford sandstone on Laredo-Dolores road at crossing of Santo Tomas Creek

Lithology and mineralogy.-Argillaceous calcareous yellowish-gray sandstone, poorly cemented and of low porosity. Smoky, white, and gray quartz constitutes about 92 percent, calcite 5 percent, clay minerals 3 percent. Heavy minerals include zircon, tourmaline, leucoxene, ilmenite, magnetite, rutile, apatite, pyrite, and biotite.

Size and shape.-Grains characteristically subangular and subrounded. Mechanical analysis: 0.147 to 0.295 millimeter, 51 percent; 0.074 to $0.147,24$ percent; less than $0.074,25$ percent.

Petrographic aralysis of post-Bigford sandstone on north side of San Pedro Hill

Lithology and mineralogy.-Hard massive argillaceous sandstone of Jow porosity. Buff with brown, reddish, and purplish mottling. Clear, rose, and smoky quartz and chert constitute about 95 percent, clay minerals 5 percent. Heavy minerals include zircon, rutile, tourmaline, leucoxene, pyrite, ilmenite, magnetite, and muscovite.

Size and shape--Grains characteristically subangular and subrounded. Mechanical analysis: 0.589 to 0.999 and 0.295 to 0.589 millimeter, a fraction of 1 percent; 0.147 to 0.295 , 65 percent; 0.074 to $0.147,27$ percent; smaller than 0.074 , 7 percent. 


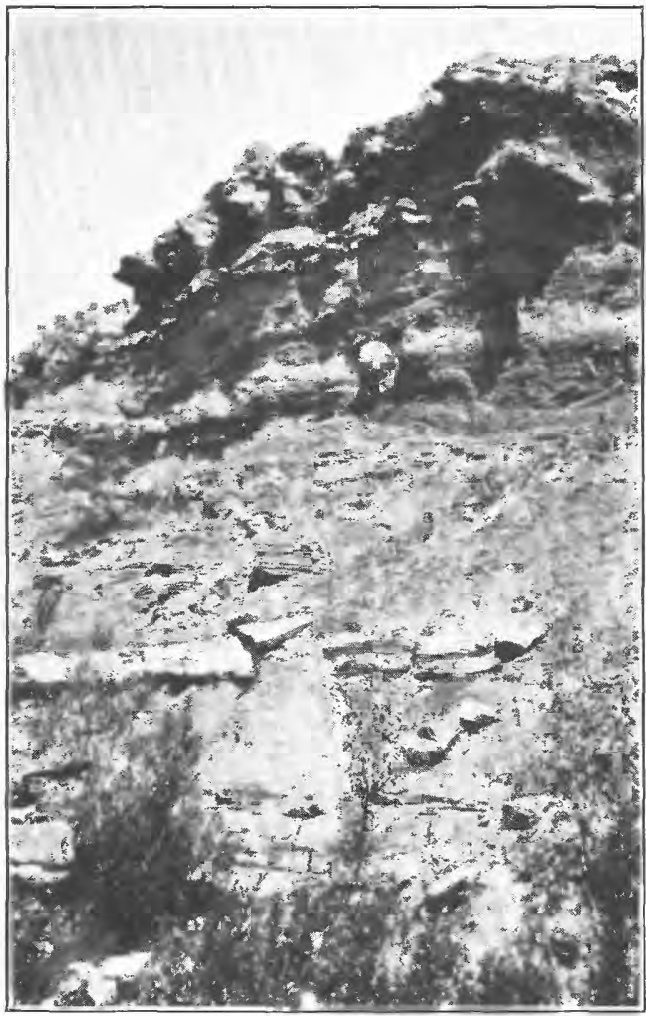

A. BIGFORD STRATA NEAR MOUTH OF SAN CIRILE CREEK.

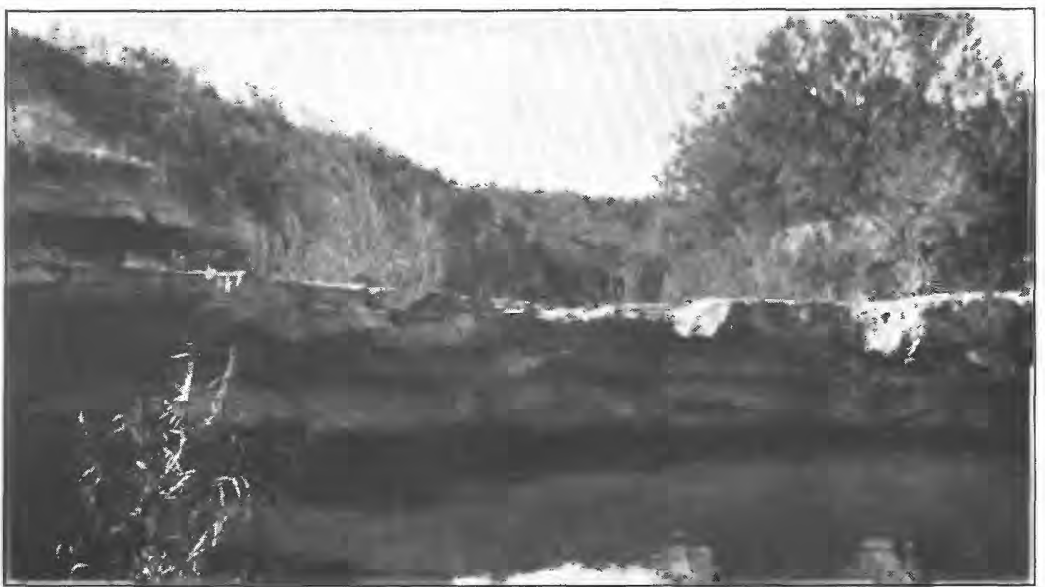

B. BIGFORD STPATA HALF A MILE ABOVE MOUTH OF SAN CIRILE CREEK. 


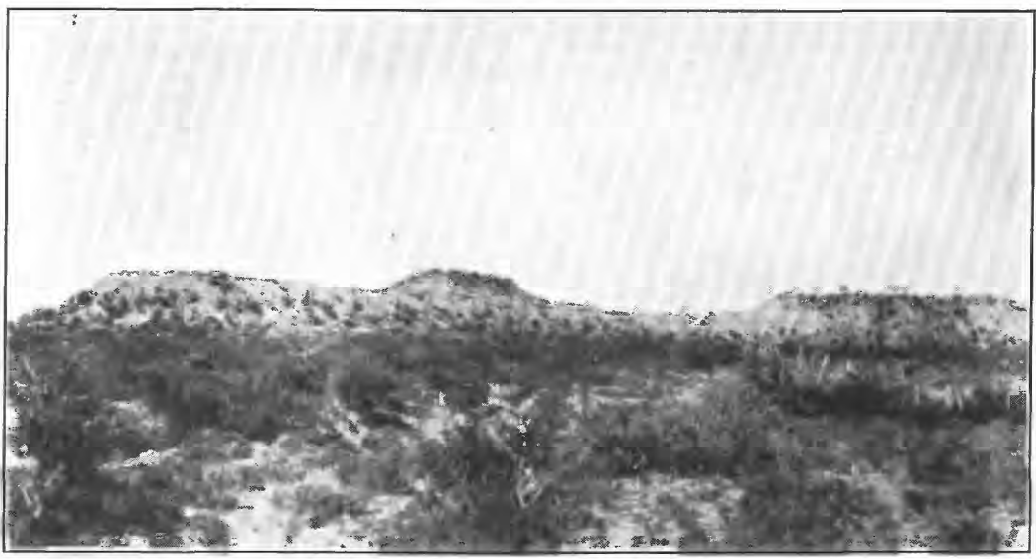

A. CUESTA FORMED BY HARD SANDSTONE BED IN POST-BIGFORD PART OF MOUNT SELMAN FORMATION HALF A MILE SOUTH OF PILOTES RANCH.

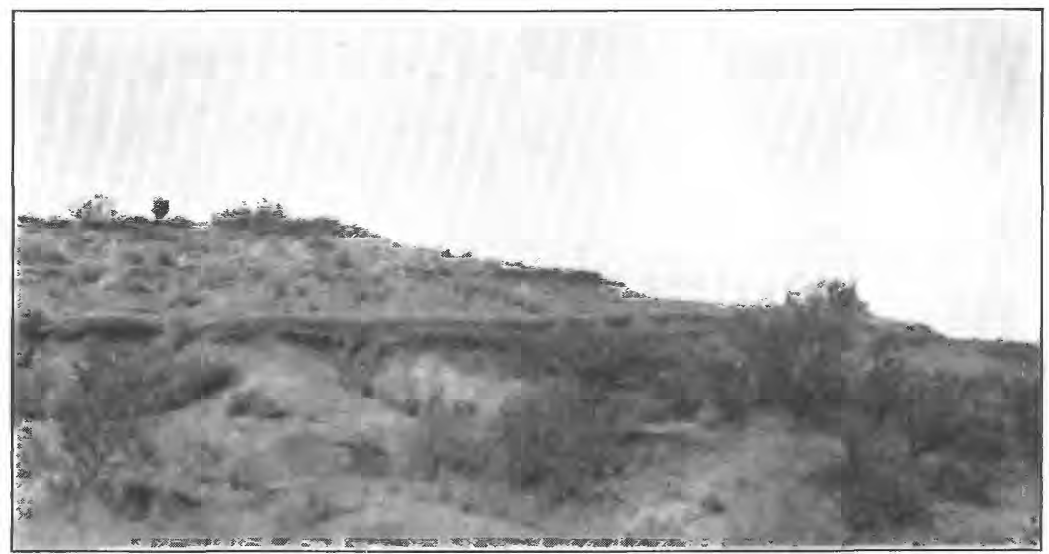

B. EXPOSURES OF SANTO TOMAS AND RELATED COAL BEDS 4 MILES SOUTHEAST OF PALAFOX. 
Petrographic analysis of post-Bigford sandstone.on Laredo-Dolores road at crossing of Santo Tomas Creek

Lithology and mineralogy.-A medium-grained argillaceous micaceous banded yellowish sandstone, incoherent, with medium porosity. Contains small clay particles of same size as quartz grains. Gray and smoky quartz constitutes about 90 percent, muscovite and clay about 10 percent. Heavy minerals include leucoxene, rutile, zircon, pyrite, garnet, magnetite, ilmenite, biotite, and tourmaline.

Size and shape.-Grains characteristically subangular and subrounded. Mechanical analysis: 0.147 to 0.295 millimeter, 1 percent; 0.074 to $0.147,79$ percent; smaller than $0.074,20$ percent.

Thickness and dip.-A composite section of the post-Bigford strata compiled from measured sections along the Rio Grande is 1,165 feet thick. The dip is about 90 feet to the mile.

Sections.-A composite section of the post-Bigford strata is given below and is shown in graphic form in figure 3 .

Composite section of post-Bigford part of Mount Selman formation

Ledge of fine-grainc $d$ massive yellow-brown and yellow mottled gray mica :eous sandstone..................

Soft yellow-brow $n$ shale and massive sandstone and alter-

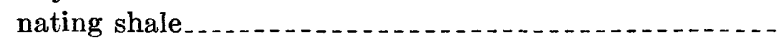

Yellow, gray, and brown clay and shale with iron concre-

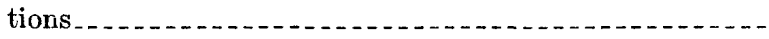

Purple, gray, and brown soft massive sandstone and alternating iron-stained gypsiferous shale ..............

Hard silty and limy concretionary yellow-gray boulders . -

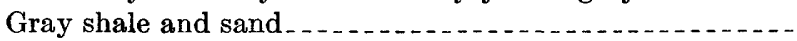

Deep-brown and dull-green sand and thin-bedded sandstone................

Soft brown sandstone and alternating gray shale ....... 1

Gray and brown iron-stained gypsiferous sandy shale _... 12

Sof $t$ rusty-brown thin-bedded sand . . . . . . . . . . . . . 1

Gray, brown, and yellow laminated iron-stained gypsiferous

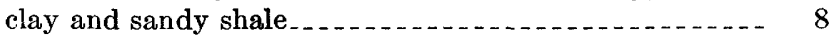

Brown, gray-pink, and purplish shale and clay _._._... 25

Sof $t$ fine-grained yellow mottled gray massive sandstone_. 6

Fine-grained brown sandstone forming a soft ledge...... 6

Soft massive yellow-brown sand . . . . .

Soft ledge of yellow-brown and gray bedded sandstone $\ldots$

Soft yellow-brown massive argillaceous sand . . . . . . . . 10

Gray and brown mottled shaly clay ................. 18

Purplish-gray and brown gypsiferous iron-stained sandy

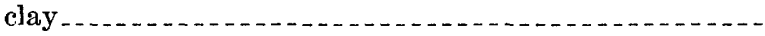

Poorly bedded sandstone with a few hard boulders 6 inches in diameter.

Gray, brown, and yellow mottled gypsiferous jointed clay - 17

Mostly clay covered by river alluvium, about . _...... 100

Soft massive poorly bedded gray sandstone........... 4

Blue-gray jointed clay ............ 4

Sof $t$ reddish, rusty-brown, and gray argillaceous sand_._- 4

Blue-gray jointed clay ............................ 6 
Composite section of post-Bigford part of Mount Selman formation-Continued

Soft yellow, brown, and gray argillaceous sandstone......

Blue-gray shale and jointed clay .......................

Ft. in.

Platy hard crystalline thin blue-gray sandstone...........

Bony black coal. .

Blue-black lignitic clay

Yellow-gray argillaceous sand $\ldots$

Covered................. 10

Thick-bedded and laminated hard gray sandstone...... 4

Gray clay with some limonite and gypsum, about_..._._. 15

Soft irregular highly cross-bedded gray sandstone....... 5

Medium-hard ripple-marked bedded gray sandstone...... 3

Blue-gray joint clay ............ 3

Brown and gray clay and partly covered, about........ 70

Brown and gray clay with some yellow limestone concretions, about.

Brown iron-stained gritty irregular sandstone, with local nonmarine fossils . ... . . . . . . . . . . . . . . . . . . .

Purple, gray, and brown thin-bedded to massive soft finegrained sandstone.....

Sandy gray and brown clay and shale with gypsiferous

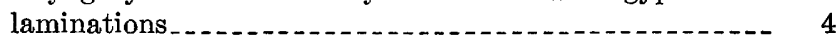

Brown, gray, pink, and purplish mottled gypsiferous clay_ 46

Hard single ledge of massive fine-grained buff and gray sandstone, in places yellow-stained . .

Yellow-brown, gray, pink, and purplish clay _......... 30

Brown and gras clay, mostly covered . . . _ _._._. 55

Brown clay _._.

Soft ledge of massive gray-brown sandstone........... 2

Gray and brown mottled jointed clay _... . . . . . . . . 15

Soft massive gray sandstone. _.

Blue-gray jointed clay _..._.

Brown clay and some yellow concretionary limestone, but

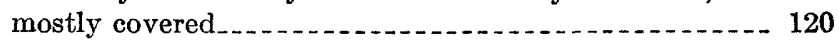

Soft massive ledge of purplish-gray sandstone, stained pink and yellow brown. .

Blue-gray and brown gypsiferous clay and a few yellow limestone concretions. . . .

Yellow limestone concretionary bed ....................

Soft thin-bedded and cross-bedded mealy gray sandstone. -

Brown clay - ..........

Clay, slight dip, about.

Brown gypsiferous clay

Shaly gray and platy buff fine-grained sandstone and some yellow-gray limestone concretions........... 2

Brown gypsiferous clay _............. 7

Thin-bedded yellow-brown gritty iron-stained sandstone_- 3

Shaly gray sandstone and shale...... 3

Brown and gray clay

Very irregular rusty-brown iron-stained sandstone with worm borings.

Brown iron-stained gritty sandstone

Brown and gray clay and sandy shale............. 6

6

6

2

7

6

1 3

4

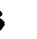

(

1

5

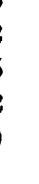


Composite section of post-Bigford part of Mount Selman formation-Continued

Soft gray sand and shaly sand._._.

Shaly gray and brown sand and clay $\ldots \ldots \ldots \ldots . . . \ldots 13$

Soft gray sand ................... 3

Brown and gray clay, partly covered............. 53

Coal seam, mostly clay....

Brown clay .............. 36

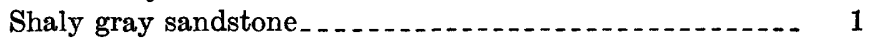

Ledge of mealy gray massive sandstone............... 1

Thin-bedded gray sandstone and gray shaly sandstone with alternate gray and brown clay................

Local ledge of hard yellow and gray boulders...........

Gray clay . . . . . .

Gritty yellow mottled iron-stained fine-grained sandstone.-

Soft ledge of fine-grained and light purplish-brown to buffgray bedded sandstone. ...................................

Soft fine-grained purplish-gray and brown sand with yellow iron-stained gypsum laminations......... 4

Blue, gray, and brown clay ....... 12

Clayey coal bed........... 1

Gray and green-brown clay _... 32

Hard ledge of buff-gray wavy laminated massive finegrained micaceous sandstone, local............... 2

Greenish-gray and brown-mottled clay .............. 18

Medium- to coarse-grained yellow-brown cross-bedded and gritty soft sandstone with yellow limestone concretions.-

Brown gypsiferous clay

Wavy bands of gypsum crystals, almost continuous and above clay.

Soft fine-grained and mealy gray sandstone with gypsum laminations and a few yellow limestone concretions... -

Brown and gray gypsiferous clay ....................

Thin hard slaty gray silty sandstone with dwarf fossils, chara seeds, and nonmarine fossils. ................

Soft fine-grained and gray thin-bedded yellow-mottled gray and brown sandstone; a few fossils at the base........

Greenish-gray and brown clay

Coal, local

Gray and brown clay

Brown shale and slaty bony coal _......... $\begin{aligned} & \text { Santo } \\ & \text { Tomas }\end{aligned}$

Black cannel coal (main Santo Tomas coal) _...- $\begin{array}{ccc}\text { Tomas } \\ \text { zone }\end{array} \quad \begin{array}{ll}\mathbf{2} & \mathbf{9}\end{array}$

Brown clay

Brown gypsiferous clay with a little soft brown sandstone at the base. . . . . .

Coal, local ...............

Hard massive yellow-stained bluish and purplish-gray sandstone

Soft shaly and thin-bedded yellow-stained gray sandstone.-

Brown clay ..........

in.

4
6

1

1

4 1

10 (1)

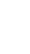
8

10

The lower part of the post-Bigford strata is composed mainly of clay with a few thin sandstone beds and several coal beds which are more or less local and which together make up the Santo Tomas coal 
zone. A few feet above the Upper Santo Tomas coal is a thin bed carrying nonmarine fossils and chara seeds, which is persistent for several miles. The following section gives these beds and their relative position with regard to the section and contact with the Bigford.

Section of lower part of the post-Bigford strata of the Mount Selman formation and of the Bigford member exposed on Santo Tomas tract 0.7 mile south of LaredoDolores road at north fence of Santo Tomas tract, 1.2 miles east of south bend of Rio Grande, and 5 miles east-southeast of Palafox

Gravel cap Ft. in.

Post-Bigford strata:

Brown gypsiferous clay 2

Soft ledge of pinkish-gray mealy sandstone.

Brown and blue-gray gypsiferous clay._._._._... 12

Ledge of limonite and concretionary gypsum with thin flaggy sandstone containing chara seed and nonmarine fossils

Black clayey coal

Green and gray-brown, very gypsiferous clay

Black and yellow flaky coal

Gray and brown clay

Yellow, brown, and gray shaly sandstone and lignitic shale

Black and brown coal (joints N. $31^{\circ}$ E.) (main Santo Tomas coal)

\section{9}

1

Greenish-gray and brown clay with a little green-brown shaly sandstone and chocolate-brown broken limonitic clay fragments.

Black coal

Brown bony coal

Yellow-gray and gray shale and shaly sand ........ Bigford member:

Thin hard yellow sandstone fragments with fossils ...

Shaly brown sand.

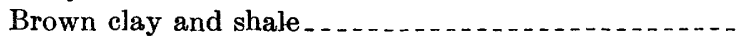

Fragments of yellow, brown, and gray shaly sandstone and gritty limonitic sandstone ............

Ledge of fine-grained gritty gray-yellow mottled sandstone

The following section is typical of the lower portion of the postBigford part of the Mount Selman formation and shows the strata from the coals up to the first prominent sandstone member. 
Section of lower part of the post-Bigford strata of the Mount Selman formation exposed on west bluff of Espadillo Creek half a mile north of Minera and 0.2 mile east of Rio Grande

Gravel cap.

Post-Bigford strata:

Ft. in.

Coarse-grained gritty brown cross-bedded soft sandstone.

Brown gypsiferous clay .............................

Wavy bands of gypsum crystals, almost continuous, with interbedded brown clay.

Soft fine-grained and some mealy gray sandstone beds with gypsum laminations and a few yellow limestone concretions

Brown and gray gypsiferous clay

Thin flaggy hard sandstone with chara seed and nonmarine fossils

Soft fine-grained gray thin-bedded yellow-mottled iron-stained sandstone and mealy gray sandstone. -

Greenish-gray and brown gypsiferous clay ..........

Black coal

Gray and brown clay.

Brown shaly coal.

Black coal (main Santo Tomas coal)

Brown clay .........

Brown shaly coal

Brown gypsiferous clay with some sandstone ledges at base

Hard black bony coal ........................ 1

Soft yellow-mottled shale and thin-bedded finegrained gray sandstone.

The following section is also in the lower part of the post-Bigford strata and is typical of the Pilotes ranch area. The upper sandstone of this section was traced for several miles.

Section of the lower part of the post-Bigford beds of the Mount Selman formation on point south of east fork of Espada Creek 1.3 miles northeast of upper road crossing, northeast of Pilotes ranch

Gravel cap.

Post-Bigford strata:

Brown clay .................. 8

Soft thin-bedded mealy sandstone......... 4

Soft gray shaly cjay

Soft mealy gray sandstone with round yellow concretions of limestone and silty boulders.................. 4

Gray and brown clay ............................ 51

Very soft gray and brown mealy massive sandstone...... 8

Ledge of massive cross-bedded micaceous, relatively soft gray, brown, and pinkish-white specked mealy sandstone in beds 6 inches to 3 feet thick .............. 18

Bluish-gray and brown gypsiferous clay _... $\ldots \ldots \ldots \ldots . . .15$ 
The middle and upper portions of the post-Bigford beds of the Mount Selman formation consist mainly of clay and therefore afford few and poor exposures. Here and there sandstone ledges form small escarpments with small exposures of the clay underneath. The first two sections below represent such exposures.

Section of upper part of Mount Selman formation on hill 0.3 mile southeast of Tordillo ranch house

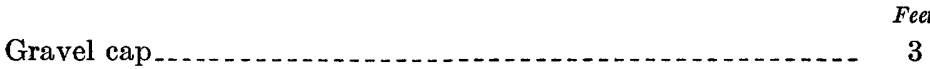

Upper beds of Mount Selman formation:

Very gypsiferous gray and brown clay and thin beds of gypsum crystals at bottom.........

Case-hardened soft, somewhat friable brown gritty ironstained sandstone................ 1

Soft massive and shaly purple, gray, and brown fine-grained sandstone, with some gypsum laminae............ 12

Gray and brown gypsiferous clay _................ 15

Section of upper beds of Mount Selman formation on hill $1 \frac{1 / 2}{2}$ miles southwest of Tordillo ranch house

Gravel and caliche cap

Upper beds of Mount Selman formation:

Brown, gray, pink, and purple clay _................ 36

Hard single ledge of massive fine-grained gray and buff compact sandstone, in places slightly yellow-stained...- 1

Yellow, brown, gray, pink, and purplish clay _._._..... 30

Section of upper beds of Mount Selman formation on north bank of Rio Grande $11 / 2$ miles southeast of San Isabel

River alluvium.

Upper beds of Mount Selman formation:

Ft. in

Soft massive poorly bedded gray sandstone ......... $4 \quad \begin{array}{llll}6 & 6\end{array}$

Blue-gray joint clay

Soft reddish, rusty-brown, and gray clayey sand..... 4

Blue-gray joint clay .................... 6

Soft yellow, brown, and gray clayey sand.......... 6

Bluish-gray shale and joint clay _................ 6

Platy thin hard buff-gray crystalline sandstone..... 2

Bony black coal. . . 7

Blue-black lignitic clay

Yellow-gray clay sand............. 2

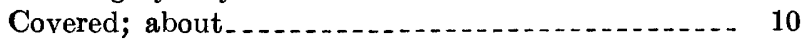

Thick-bedded and laminated gray sandstone; dips $1^{\circ}$

S. $70^{\circ}$ E. and has prominent jointing in same direc-

tion._.

Gray clay with some limonite and gypsum _........ 15

Soft irregular, highly cross-bedded gray sandstone... 5

Harder bedded ripple-marked gray sandstone....... 3

The next two sections are typical of the upper part of the Mount Selman formation, showing its contact with the overlying Cook Mountain formation in the area near the Rio Grande northwest of Laredo. Exposures are so few in the northern part of the area that 
no good section of the strata immediately below the Cook Mountain contact can be given.

Section on southward-facing escarpment half a mile northwest of El Pico Hill

Caliche and gravel cap.

Cook Mountain formation: Ledge of fine-grained massive yellow-brown and gray-yellow mottled micaceous sandstone. Upper part of Mount Selman formation:

Soft brown shaly to massive fine-grained sandstone and yellow and greenish-gray thin-bedded sandstone with alternate beds of blue-gray shale and clay and ironstained sandy shale

Yellow, gray, and brown clay and shale with iron concretions.

Purple, gray, and brown soft massive sand and alternate shale with iron and gypsum concretions ...............

Hard silty and limy concretionary yellow-gray boulders.-

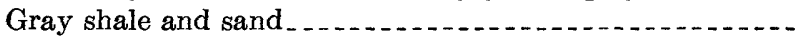

Deep-brown and dull-green sand and thin-bedded sandstone.

Soft brown sandstone and alternate gray shale

Gray and brown sandy shale with iron and gypsum concretions.

Soft rusty-brown thin-bedded sand ---

Gray, brown, and yellow laminated clay and sandy shale with iron and gypsum concretions

Section on south bluff of creek 0.6 mile southeast of El Pico Hill

Cook Mountain formation:

Purplish-brown lignitic shale

Massive fine-grained irregular yellow and gray mottled sandstone, unconformable on the underlying sandstone.

Massive pink, reddish-brown, and gray medium-grained friable sugary sandstone, forming a single ledge.......

Covered

Very thin bedded to massive yellow and gray mottled irregular fine-grained sandstone with much yellow iron oxide.

Ledges of soft pink, gray, and brown medium-grained friable laminated sandstone in beds 4 to 6 inches thick.-

Yellow and gray mottled rusty irregular sandstone.....-

Soft dull-brown fine- to medium-grained, loosely cemented sandstone in beds 2 to 6 inches thick, with alternate layers of yellow and gray mottled shaly sand 1 to 3 inches thick.

Upper part of Mount Selman formation:

Soft, very thin bedded shaly yellow and gray mottled sand to massive lavender and yellow sandy shale...........

Darker-greenish and blackish-gray and yellow, brown, and gray mottled sandy shale and lignitic shale........... 4

Blackish, bluish-gray, irregularly yellow-mottled gypsiferous jointed sandy shale and clay and bluish-black shaly sand. 
Water supply.-The water obtained from the post-Bigford part of the Mount Selman formation by wells in Webb County is scanty and of poor quality. The sandstones generally are thin, and the rocks commonly contain considerable gypsum and other soluble minerals. In the outcrop area of this part of the formation water is generally obtained either from earthen reservoirs or tanks in which storm waters are impounded or from wells drilled to the Carrizo sand. An analysis of water from one well (no. 66) in this part of the Mount Selman formation is given on page 102 .

Wells $74,75,91$, and 99 (see table, p. 92) are drilled in the upper beds of the Mount Selman. The wells are 425 feet in maximum depth and yield small amounts of salty or bitter water suitable for stock. Well 76, east of the outcrop area (see pl. 1), is 207 feet deep and probably penetrates to the upper beds of the Mount Selman. The well yields small amounts of potable water, which, however, may be coming from the Cook Mountain formation.

Several wells in the northern part of the outcrop area in Webb County have been drilled through the post-Bigford beds and the underlying Bigford member into the Carrizo sand. According to report these wells encountered a few water-bearing sands above the Bigford member, but the water in them was invariably salty. Close to the western boundary of the outcrop area the wells reached the Carrizo sand at depths of 1,208 to 1,350 feet. In the eastern part of the outcrop area well 19 reached the Carrizo sand at 2,074 feet. In the southern part of the outcrop area few wells have been drilled to the Carrizo sand. Two oil test wells, 20 and 74 , encountered the Carrizo sand at depths of 1,610 and 1,708 feet, respectively. In well 20 a water sand was encountered at 970 feet in the post-Bigford part of the Mount Selman. In well 74 water sands were encountered at depths of $800,1,075$, and 1,340 feet, the first two in the post-Bigford beds and the third in the Bigford member. No information is available as to the character of the water in these sands.

\section{COOK MOUNTAIN FORMATION}

General features.- The Cook Mountain formation crops out in a belt 10 to 18 miles wide extending in a north-south direction through the central part of the county (pl. 1). The Missouri Pacific Railroad follows approximately the center of the outcrop area from the north county line to Laredo. South of Laredo the complete outcrop is not present in Webb County, some of it being on the west side of the Rio Grande in Mexico. From the north county line to the vicinity of Webb the topography is rolling and does not have much relief. From Webb to the south county line the outcrop area is included in the breaks of the Rio Grande and is rougher. The formation -supports a dense growth of chaparral. The lower contact is generally marked 


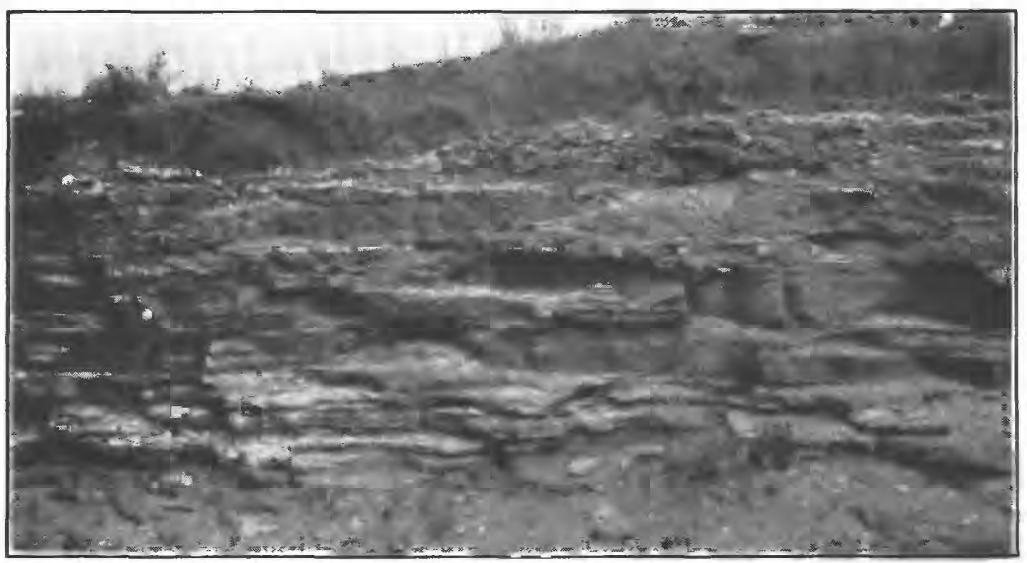

A. FOSSILIFEROUS SHALE AND SANDSTONE NEAR BASE OF THE COOK MOUNTAIN FORMATION ON THE LAREDO-DOLORES ROAD AT THE WEST FORK OF SAMBARIETO CREEK.

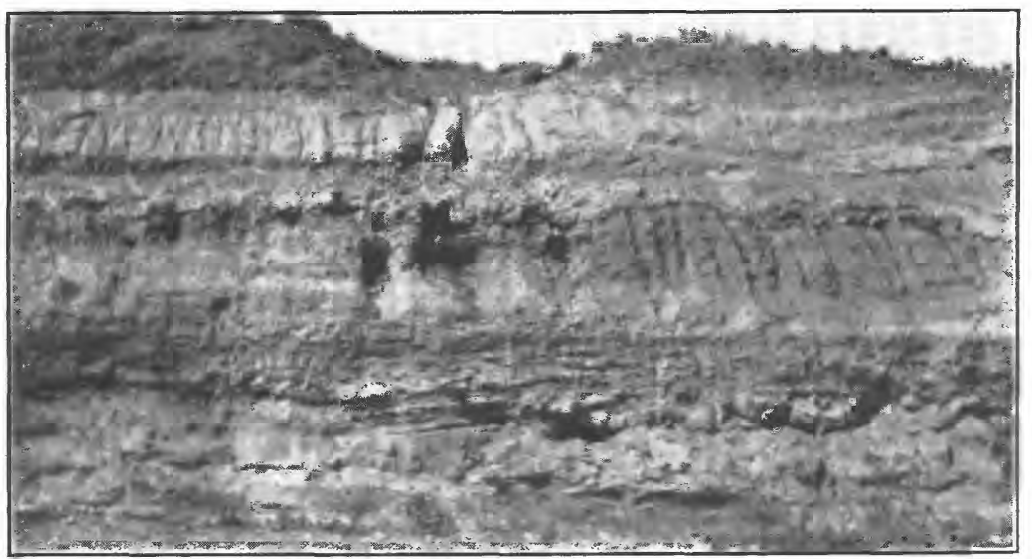

B. SANDSTONE AND SHALE IN TOP OF MIDDLE PART OF COOK MOUNTAIN FORMATION 2.9 MILES SOUTHEAST OF LAREDO POST OFFICE. 

by a gentle westward-facing cuesta. The Cook Mountain is conformable on the upper part of the Mount Selman formation.

Lithology.-The Cook Mountain formation is composed of sand, sandstone, clay, thin limestone, and marl. Most of the sandstone is medium-grained, but there is a considerable variation in grain size. The sandstone is brown, red, gray, or green, and much of it is glauconitic and weathers into bright-red sandy soil. Here and there

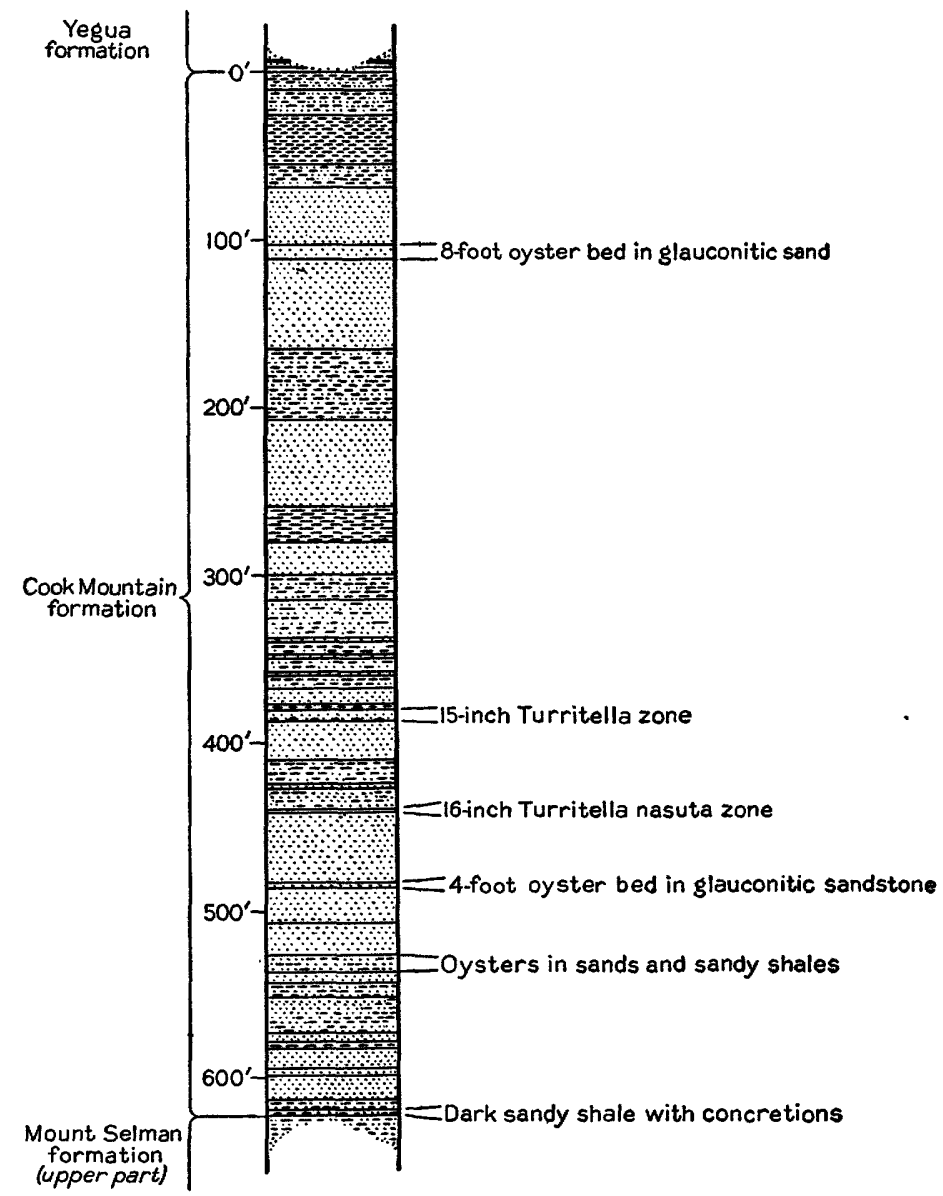

FiguRE 4.-Composite columnar section of the Cook Mountain formation showing predominance of sand and sandstone members.

sandstone beds are indurated to quartzite. The clay is yellowish, grayish, greenish, or chocolate-colored and includes minor lenses of bentonite. Much of the limestone is concretionary, and in places it is a marl rather than massive limestone. Fossils are abundant in the formation.

Sandstone is the most abundant constituent of the Cook Mountain formation. In the composite section shown in figure 4 it constitutes 
more than 50 percent of the formation. This section represents conditions in the Laredo region, where exposures are most abundant. Farther north there is relatively more clay in the upper third of the formation. This results in a belt of clay lands in the eastern part of the outcrop area, in the northern part of the county, greatly in contrast to the sandy soil in other parts of the area.

Laboratory analyses.-The sandstone and sand vary considerably in texture. Probably the average is medium- to fine-grained. Samples that have been analyzed show 68 to 88 percent of the grains from 0.074 to 0.250 millimeter, 10 to 30 percent less than 0.074 millimeter, and about 2 percent larger than 0.250 millimeter. The grains are angular to subangular, with few rounded grains except for glauconite in the glauconitic varieties. The minerals present include quartz, feldspar, glauconite, tourmaline, zircon, muscovite, magnetite, ilmenite, staurolite, garnet, rutile, and leucoxene.

Thickness and dip.-The thickness of the formation in the sections measured near Laredo is 630 feet. It is probably greater in the northern part of the county, and in wells east of the outcrop area the formation reaches a thickness of 875 feet. The dip is about 85 feet to the mile.

Sections.-The composite section in figure 4 is compiled from sections measured at intervals along the Rio Grande above Laredo and from sections along Chacon Creek east of Laredo and along the Corpus Christi-Laredo highway. This section represents conditions in the general region of Laredo and probably is approximately representative of the Cook Mountain farther north and south. Unfortunately, continuous or even discontinuous exposures of the formation are not present in other areas.

The composite section shows a relatively large proportion of sandy beds. In the northern part of the county, from the general locality of Webb to the north county line, a large proportion of shale or clay is found in the upper part of the formation, and the sands of the upper part are more argillaceous than in the Laredo region. This condition. is probably due to the presence of a clay lens in the Webb region that is overlapped farther south.

Detailed sections from which the composite section was compiled are given below. The first four sections are in great detail and are available through the cooperation of Julia A. Gardner. It is possible to correlate these sections by reference to the fossiliferous beds present. When this is done it is found that the section is not of uniform thickness in its various parts, owing, no doubt, to lensing of members. The location of these sections is shown in figure 5. Views of exposures of Cook Mountain strata are shown on plate 10. 


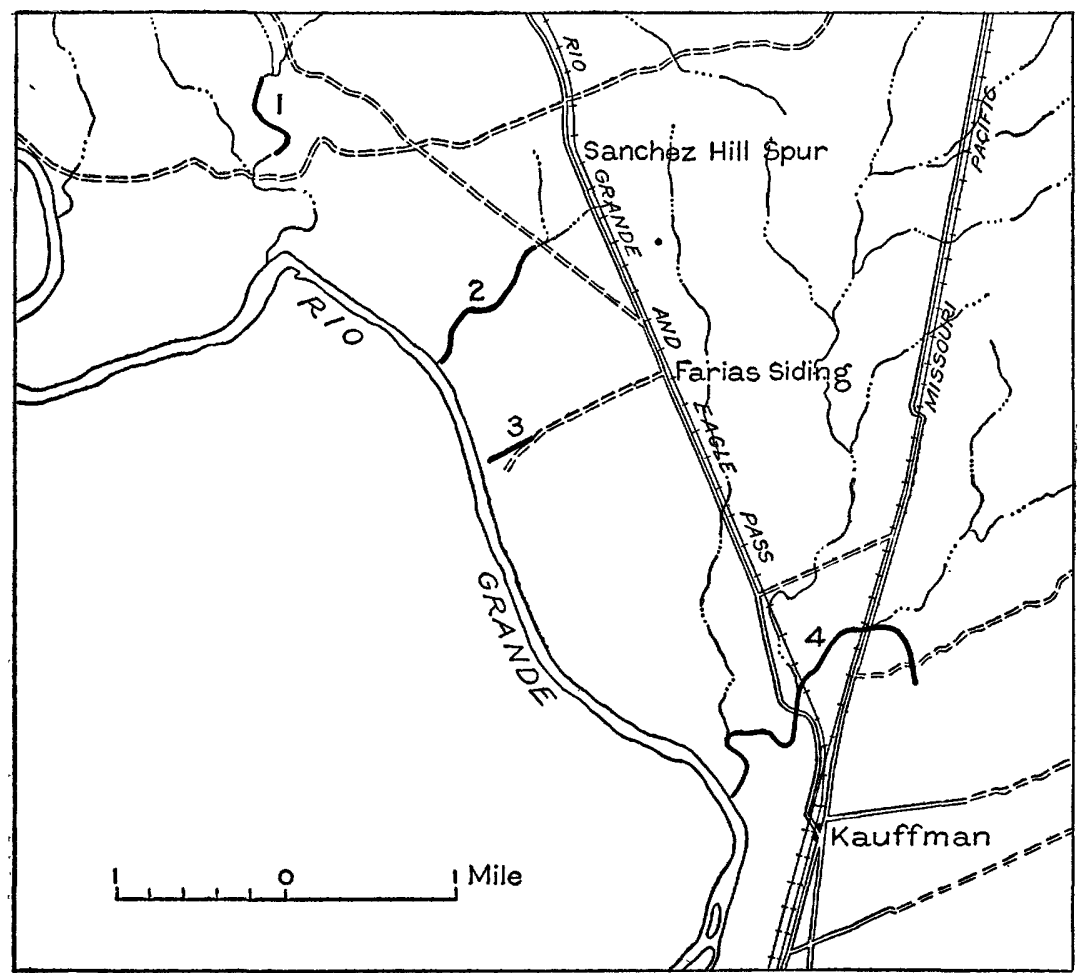

FIGURE 5.-Sketch map showing location of measured sections of Cook Mountain formation.

Section of Cook Mountain and Mount Selman formations along Sambarieto Creek

[Location 1, fig. 5]

Cook Mountain formation:

17. Bedded, loosely cemented greenish-yellow finegrained glauconitic sand with some thinnerbedded shaly sand; some cross-bedding and scattered clayey sand.....................

16. Indurated fossiliferous sandstone with Ostrea, Callocardia astartoides, and a rather large $\mathrm{Ce}$ rithium, highly ornamented ...............

15. Bedded and cross-bedded sand and clay, very similar to those beneath, the cross-bedded sand occupying the upper 1 to 2 feet; a few Ostrea..
Ft. in. 

Section of Cook Mountain and Mount Selman formations along Sambarieto Creek-
Continued

[Location 1, fig. 5]

14. Highly fossiliferous glausonitic, strongly crossbedded, firmly indurated greenish-gray sand, weathering dark brownish gray and breaking with a hackly fracture; contact conspicuously undulated; unconformity also suggested by the large pellets of glauconite, the trashy character of shell fragments, and pipes above and below the contact but not crossing it. Horizontal veinlets of calcite common. Contains Ostrea, Callocardia, Natica dumblei, Cornulina, Phos...

13. Massive to thick-bedded, very fiue, slightly glauconitic brown-weathering sand with a few shaly partings and lenses of brilliantly colored ribbon sand

Ft. in.

12. Thin-bedded ferruginous glauconitic sand; the bedding planes in the lower part of the section wavy and dark brown; the sand above more massive and greenish gray

interwoven shale dusted with copiapite and interwoven wavy bedding planes stained brown; upper beds more sandy, mottled gray and brown in the unweathered section and grading into beds above ... ................

10. Thick-bedded sand and thin shale; sand lightsolored (gray and buff), weathering dark. Salt incrustations . . . . . . . . . . . . . . . . . . .

9. Purple casehardened sandstone, the upper surface very uneven, with tabular and fucoidal excrescences

8. Massive salmon-colored and brownish-red sand, not cemented, fine-grained, consisting mainly of glittering transparent quartz grains with smaller amounts of rose-colored quartz, glauconite, and dark-colored minerals; contact with overlying bed undulated, emphasized by partings of thin clay; 4-inch onion concretions of indurated sandstone; others much larger not so well formed. Limonite pipes at right angles to contact and many fucoidal markings parallel to bedding.

7. Chocolate-brown shales dusted with yellow, weathering purplish brown, gypsiferous .......

6. Sugary fine-grail.ed light-gray to lavender-brown sand and sandstone, mottled, thick-bedded, with a curious wormy weathering and tubular impressions and molds, parallel with the bedding; a few interbedded sandy shales. .........

5. Fine-grained light-gray lenticular quartzitic sandstone, weathering smooth, dark, and flaggy, recrystallized faces that shine like muscovite and numerous dark specks, in part glauconite.. 
Section of Cook Mountain and Mount Selman formations along Sambarieto CreekContinued

[Location 1, fig. 5]

4. Fine-grained light-gray sandstone, the well-defined beds from a fraction of an inch to 8 inches in . thickness, commonly friable, stained with iron oxide; some of the thin beds, particularly in the lower portion, sunburned or casehardened and fucoidal; lower thin-bedded series about 1 foot thick and more resistant than the beds immediately above

Mount Selman formation:

3. Very sandy shale, mottled lavender and reddish brown, netted with wavy bedding planes that are darker brown than the beds they separate; the sandy shale grading upward into a lightergray, more horizontally bedded fine argillaceous sandstone; upper 2 feet carrying numerous plant impressions, light gray and dusted with copiapite; gypsum commonly present along the bedding planes

Fi. in.

2. Sand and sandy shale, glauconitic, medium-gray, weathering brownish, carrying flattened concretions (mud balls?) as much as 3 inches in diameter.

1. Dark-gray to black sandy shale, grading upward into mottled gray sandy shale carrying transversely elongate biscuit-shaped concretions as much as 14 inches across. Concretions gray, weathering buff, medium-grained, firmly cemented, glauconitic, the glauconite grains small and light green

Section of Cook Mountain formation in first arroyo 1.2 miles south of Sambarieto Creek

[Location 2, fig. 5]

14. Oyster bed.

Ft. in.

13. Yellowish-brown, loosely cenented bedded sandstone; terraced weathering ........................

12. Resistant ferruginous sandstone, apparently unfossiliferous ... . . . . . . .

11. Bedded yellow sand; a part of the section obscured, loosely cemented, very fine grained, with minute specks of glauconite; terraced weathering

10. Massive flaggy sandstone, highly indurated, locally cross-bedded, with highly fossiliferous layers and pockets. Callocardia conspicuously abundant......

9. Bedded but not indurated yellow sand grading down into a firmly indurated pavement sandstone breaking into flags that cross the arroyo at N. $30^{\circ}$ E.; surface of the pavement irregular and scooped into shallow hollows ....................................

8. Yellowish-brown, poorly bedded sandstone, finegrained and sugary, loosely indurated........... 
Section of Cook Mountain formation in first arroyo 1.2 miles south of Sambarieto Creek-Continued

[Location 2, fig. 5]

7. Indurated sandstone forming the bed of the broad arroyo; gray weathered surface netted with fucoids 1 to 2 inches in diameter, parallel to the bedding plane and reticulate; a few small Ostrea alabamiensis and Cornulina?

Ft. in.

6. Thinly laminated micaceous granular glauconitic sand-

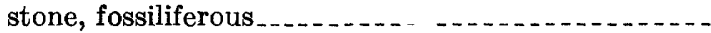

5. Shaly sand with copiapite and iron oxide stains outlining the bedding planes; very prominent steeply dipping joint planes. .............................

4. Fine-grained micaceous glauconitic yellow and brown sand, well bedded, thin to rather thick, weathering bright red

3. Cross-bedded sand, locally quartzitic, with large and irregular pellets of glauconite and pipes that do not cross the contact with bed beneath; probably bed 14 of section 1

2. Massive sandstone, weathering brownish yellow, laminated

1. Hackly glauconitic sandy shale, weathering red on the cleavage planes, concretionary and spalling off the rounded face of the arroyo scarp................

Section of Cook Mountain formation at Faria pump

[Location 3, fig. 5]

7. Resistant ledge-making sandstone, apparently unfossiliferous

6. Chocolate-brown shale dusted with copiapite and stained with limonite; highly gypsiferous. The rounded contours and purplish coloring, together with the limonite shingle upon the upper surface, make them conspicuous topographically

5. Soft terraced yellow-brown sand, the beds a few inches thick and commonly coated with caliche along the exposed surfaces. . .

4. Highly glauconitic greenish-gray sand with a seedy weathering, concretionary, the concretions as much as 4 feet across and highly fossiliferous in the pockets and outer layers; weathering surface dark grayish black, but the sand within is commonly light gray and friable; Ostrea, Callocardia astartoides, Volutocorbis, Architectonica, Cerithium webbi possibly the most characteristic fossils. Probably equivalent to bed 15 of section 1 and beds 6 and 7 of section 2

3. Harsh, somewhat clayey yellow-brown and red sand, obscurely or not at all bedded, carrying pecan-sized concretions; mottled pink and lavender on the outcrop; steeply dipping joint cracks filled with gypsum and

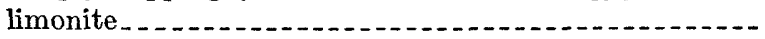


Section of Cook Mountain formation at Faria pump-Continued

[Location 3, fig. 5]

Feet

2. Bedded sand; the upper part of the section highly colored, red mottled with unstained gray sand; both the red and the gray very fine grained and friable; mostly angular transparent quartz grains with a few dark specks of glauconite and possibly some mica; a few limonite pipes and partings

1. Thin-bedded sand and sandy shale, iron-stained along the bedding planes, incrusted with salt in many places, the sand fine-grained, sugary, and yellow-brown..........

Section of Cook Mountain formation on hill 1 mile northeast of the Texas Mining \& Smelting Co.'s smelter through Manadas Creek to the Rio Grande

[Location 4, fig. 5]

16. Closely packed but not indurated, very fine grained sandstone; the component grains mostly angular clear or amber quartz, with numerous small rounded glauconite grains; sandstone bedded and protected on the top of the hill by gravel and caliche.

15. Indurated concretionary, highly calcareous sandstone, holding up the hill; packed with Turritella nasuta and Mesalia, with Venericardia, large and small Natica $d u m b l e i$, and other gastropods and bivalves present in smaller numbers

14. Yellowish-brown and gray glauconitic sandstone, very similar to that overlying the concretionary bed but less uniform in color and composition; very harsh, mottled, with some pockets of clear gray sand and numerous small flakes of muscovite; the upper 5 feet forming a narrow bench, protected by the hard bed above; the lower 15 feet or so covered............

13. Indurated layer not differing greatly from that above; slightly coarser grain, more closely packed and for that reason more resistant, grayish rather than yellowbrown, carrying less yellow quartz; glauconitic.......

12. Very fine grained ferruginous sand, weathering to a brighter red than the sand above and thinner-bedded upon the weathered surface; limonite shingle.........

11. Sandy shale with ferruginous partings and limonite shingle with a few sand beds, one of them at least 2 feet in thickness. Bed for the most part covered, and as the gradient of Manadas Creek is very low, the thickness is only an approximation

10. Very fine closely packed sand, greenish black when wet; irregularly netted both horizontally and diagonally with gypsum seams; doubtless of very recent formation . . .

9. Fine-grained sand and sandy shale, weathering in long, deep furrows parallel to the stream channel; all angles rounded off; potholes in the process of formation.

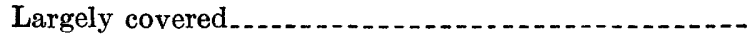


Section of Cook Mountain formation on hill 1 mile northeast of the Texas Mining \& Smelting Co.'s smelter through Manadas Creek to the Rio Grande-Con.

[Location 4, fig. 5]

8. Dense indurated sandstone blocks or slabs with a crossbedded layer in the middle packed with Turritella nasuta; other species represented but less abundantly; slabs commonly break in the middle, leaving the fossiliferous portion exposed and weathering in cross section; Ostrea present in the same bed but slightly lower. This unit forms the bed of the arroyo directly upstream from the railroad bridge and is exposed along the east bank of Manadas Creek to a point a little below the bridge on the Mines road, where it caps and protects the sand and shale.

7. Sand and sandy shale, increasingly carbonaceous and lignitic toward the base and downstream; copiapite dusted along the bedding planes.

6. Indurated fossiliferous glauconitic sand bedding the stream, with a maximum thickness of 18 inches, playing out abruptly in the carbonaceous shale and leaving no trace in the subsequent section; Ostrea the most common fossil; other forms present include Cerithium webbi, Pseudoliva, Natica dumblei, Callocardia, and a colonial coral. Equivalent of bed 4 of Faria pump section, bed 6 of section in first arroyo south of Sambarieto, and bed $\mathbf{1 6}$ of Sambarieto section

5. Carbonaceous shale series continuous downstream with bed 7 and indistinguishable from it; separated from it upstream by bed 6 . Dip $2 \frac{1}{2}^{\circ} \mathrm{S} .30^{\circ} \mathrm{E}$

4. Fine-grained glauconitic yellowish-brown sand, firmly packed but not indurated, massive in section but weathering with an obscure bedding; deeply furrowed parallel to the stream channel; thickness only approxi-

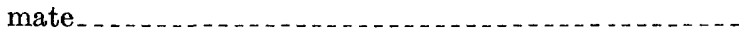

3. Glauconitic sandstone carrying many impressions of "fucoids" in branching compressed tubes an inch or two across, parallel to the bedding plane; enormous concretions of cross-bedded, apparently unfossiliferous sandstone weathering in curious honeycomb shapes locally present in the upper portion...............

2. Sharply defined, highly indurated calcareous sandstone, finished like a paving block above and below; the looser, more glauconitic medial portion packed with fossils; a small Callocardia the dominant form; Cerithium webbi, Oculina, Fusinus, Natica dumblei, Pseudoliva (2 species), turritids, and other species of a prolific and diversified fauna present. A rather large piece of fossil wood also noted.

1. Closely packed dark greer.ish-black glauconitic fucoidal sand with dark-gray sandy concretions a foot or more in diameter and horizontally laminated; glauconite grains of various sizes present, and usually an oyster or some other organism suggesting an organic nucleus. Pyrite concretions not quite so large as golf balls also present in considerable numbers. 
The section below was measured east of Laredo. It is extended to include the contact with the overlying Yegua formation. Bed 15 of section 4 given above is probably correlative with the lowest bed shown in this section. This section and the four previously given show, therefore, a complete section of the formation.

Section along Corpus Christi highway from a point 4.4 miles east of Chacon Creek west to a point 0.6 mile east of Chacon Creek

$\begin{array}{lrr}\text { Yegua formation: } & \text { Ft. } & \text { in. } \\ \text { Oyster bed... } & 2 & \\ \text { Yellow selenitic clay } & 4 \\ \text { Oyster bed..... } & \\ \text { Yellow-brown gypsiferous clay } & \end{array}$

Cook Muuntain formation:

Yellow gypsiferous sandy shale with limestone cóncretions. . . . . . . .

Purple and green clay

Brown clay . . . . . . . . . . . . 11

Greenish and reddish gypsiferous sandy clay _...... 8

Green sandy clay _................. 6

Green and yellow sandstone.................. 34

Green glauconitic sandstonc ........... 11

Glauconitic green sandstone with oysters _......... 8

Greenish and yellowish argillaceous sandstone _..... 53

Greenish glauconitic sandstone................ 1

Gray and yellow gypsiferous clay ................ 33

Red and gray medium-grained sandstone . . . . . . . 15

Yellow medium-grained sandstone................ 27

Brown fine-grained sandstone............... 10

Gray gypsiferous clay ....................... 21

Medium-grained soft yellow sandstone _............ 19

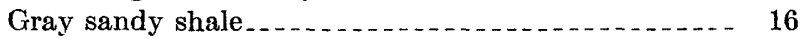

Yellow medium-grained sandstone with thin streaks of clay .......... 22

Thin-bedded red sandstone ................... 2

Interbedded gray shale and sandstone............. 8

Thin-bedded yellow sandstone................... 2

Gray sandy shale................. 8

Soft yellow sandstone . .

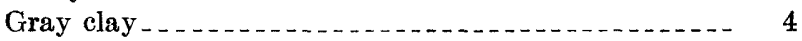

Yellow and gray cross-bedded sandstone, with fossil bed at base......... 6

Sections along the Mount Selman-Cook Mountain contact in areas north of Laredo are given below. Notes on sections along the upper contact are given in the discussion of the Yegua contact.

Section 4.1 miles east of Spohn ranch

Cook Mountain formation:

Reddish-brown sugary sandstone. ........................

Yellowish-brown and gray banded and friable soft sand-

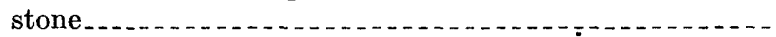

Mount Selman formation: Gray shale and clay and shaly sand, with veinlets of gypsum, about 
Section $2 \frac{1}{2}$ miles southeast of Jefferies ranch

Cook Mountain formation:

Red and reddish-brown soft, poorly cemented sugary sandstone in beds 4 inches to 1 foot thick . . . . . . . . . . . . . . .

Thin-bedded dull-gray and brown sugary sandstone and shaly sandstone with limonite stains.

Mount Selman formation: Gray and brown mottled clay

3

A section showing conditions in the basal part of the formation is given below:

Section of basal part of Cook Mountain formation 2.3 miles northeast of Clifton ranch and $5 \frac{1}{2}$ miles west slightly south of Green siding

$\begin{array}{lr}\text { Brownish-yellow sandstone, fossiliferous } & \text { Feet } \\ \text { Yellowish-brown and gray sandstone._. } & 1 \\ \text { Calcareous fossiliferous sandstone } & \\ \text { Compact fine-grained yellowish-brown micaceous sandstone } & 8\end{array}$

Near this locality in the creek north of the Clifton ranch occurs a bed 1 foot thick of creamy-gray bentonite. The bed cannot be traced beyond the exposure in the creek.

North of the breaks of the Rio Grande exposures of the Cook Mountain are generally not as abundant or of as great vertical extent. The contact of the Mount Selman and the Cook Mountain is generally marked by a cuesta, along which there are many small sections. These generally show brown and red sandstone of the Cook Mountain formation overlying clay, sandy clay, and grayish or brownish sandstone of the Mount Selman.

Exposures of thick sections of the middle and upper part of the formation are lacking in the northern part of the outcrop area. Cerrito Prieto, a prominent hill 4 miles northwest of Cactus, is capped with 5 feet of massive porous, highly fossiliferous limestone, beneath which is 25 feet of soft fine-grained greenish-brown, slightly glauconitic sandstone and shale. The fossiliferous limestone crops out again at the San Roman ranch and probably is equivalent to the sandstone exposed on the highway 1 mile north of Chilton. Northwest of Encinal there are many shallow exposures showing sandstone, fossiliferous sandstone, and a few ledges of fossiliferous limestone.

Trowbridge ${ }^{20}$ has described a number of sections of the formation in Webb County in addition to these mentioned here. Most of these sections are in localities in the breaks of the Rio Grande and are correlative with the first five sections given above.

Sections in wells.-The driller's' logs of wells $40,45,61,88,96,125$, and 129 (see pp. 88, 94, 96) show the character of the Cook Mountain formation in different parts of the county, both in the outcrop area and down the dip where it is under cover. Wells 40,61 , and 129 are drilled in the outcrop area and do not penetrate to the Mount Selman formation.

20 Trowbridge, A. C., op. cit. (Bull. 837), pp. 107-124. 
The logs of these wells show alternating beds of sandstone and clay, which are characteristic of the middle and lower parts of the formation throughout the outcrop area in Webb County.

Well 45 is a deep oil test, and only part of the log is shown. The beds are classified as Cook Mountain from the surface to a depth of 409 feet and as Mount Selman below that depth. The log shows that there is a distinct difference in the lithology, the Mount Selman formation containing more shale and clay, and the Cook Mountain more sandstone. Well 125, in the southern part of the outcrop area, illustrates much the same condition. In this well the contact of the Cook Mountain and Mount Selman is at 278 feet, and there is again a change to more shaly beds in the lower formation.

Well 88 illustrates the character and thickness of the beds encountered in wells drilled into the Cook Mountain formation down the dip to the east of the outcrop area. The correlation of the beds is difficult because of the lack of detail in the $\log$, but it is believed that the lower 605 feet is Cook Mountain and that all above that depth is Yegua. The thickening of the formations down the dip and the relatively large proportions of clay in the upper part of the Cook Mountain are shown by this log. Well 96 shows a somewhat clearer division of Yegua and Cook Mountain strata. The contact is at 477 feet, and the strata below this depth contain more sandstone beds than those above. Well 136 is the deepest well in Webb County drawing water from the Cook Mountain. The beds in the upper 2,143 feet in this well are thought to belong to the Jackson and Yegua formations, and the water sand from 2,143 to 2,160 feet is thought to be Cook Mountain

Water supply.-The Cook Mountain formation is an important source of water for domestic use and irrigation and a potential source of water for additional irrigation. The composite columnar section of the formation (fig. 4) shows several beds of sand or sandstone that are water-bearing. Although this section represents conditions near Laredo, it is also generally representative of the formation elsewhere in Webb County.

Successful wells are obtained in the Cook Mountain formation over practically all of its outcrop area and for considerable distances to the east of the outcrop. The wells range in depth from less than 100 feet to 2,300 feet. Plate 11 shows tentative correlations of wells in the northern part of the county, based on wells for which accurate data are available.

Of the wells represented in this plate wells 27,29 , and 61 are in the outcrop area, well 27 being about 4 miles east of the Mount SelmanCook Mountain-Yegua contact. Wells 27 and 29 penetrate three beds of water-bearing sand, the top of the principal bed being encountered at depths of 373 and 458 feet, respectively. Well 61 penetrates several beds of water-bearing sands, the best one 12 feet thick, 
at depths of 538 to 550 feet. This well is used for irrigation. Wells $65,88,90$, and 136 are east of the outcrop area and pass through Jackson and Yegua strata before encountering the water-bearing sands of the Cook Mountain formation. From the diagram it will be seen that the formation and its water-bearing sands are found at progressively greater depths to the east of the outcrop area.

In the vicinity of Laredo and to the south of it successful wells are obtained in the Cook Mountain at depths ranging from 72 to 600 feet, depending on the location of the well and character of the section which it encounters. For example, well 123, 72 feet deep, just north of the city limits of Laredo, encountered salt water at a depth of 25 feet but from 28 to 72 feet penetrated a sand that yields sufficient fresh water to irrigate half an acre. Well 124, in the eastern part of Laredo, is 250 feet deep, and its principal supply comes from 35 feet of waterbearing sand at 200 to 235 feet. The principal water-bearing bed in well 131 is from 350 to 375 feet deep. In most of the wells more than one water sand was found, and in general the lower sands supply more and better water than the upper sands. Data on additional wells are given in the table of well records and on plate 1.

The level of the water in wells drilled to the Cook Mountain formation varies greatly. Well 88 is a flowing well. In nonflowing wells for which records were obtained levels range from 25 to 186 feet below the ground, depending on the depth of the well and its location. In general in the outcrop area the water level in the shallow wells is higher than in the deeper wells. In the deeper wells used for irrigation the depth from which the water must be raised ranges from 100 to 150 feet, from one end of the outcrop area to the other. East of the outcrop area the water levels in Cook Mountain wells are generally less than 100 feet below the surface, and in those wells that are located in the valleys they are very much less.

Few accurate measurements of the yield of wells in the Cook Mountain formation are available. Most of the wells are pumped by windmills, and drillers' estimates of the yield range from 5 to 45 gallons a minute. A few wells are equipped with irrigation pumps whose discharge has been accurately gaged. Well 68 is reported by the owner to have been pumped at the rate of 150 gallons a minute for 21 days and nights, the yield amounting to 216,000 gallons, or slightly more than two-thirds of an acre-foot, each 24 hours. The water level in this well, which normally stands at 100 feet, was drawn down to 165 feet during the pumping. The well draws water from three waterbearing sands. It is reported that wells 57 to 61 have each been pumped at the rate of 175 gallons a minute for several days, but there is no record of the amount of the draw-down during the pumping. Other wells used for irrigation are reported to have been pumped at rates ranging from 45 to 90 gallons a minute for comparatively long periods without failure. 
Available analyses $(27,32,41,57,78 \mathrm{a}, 86,88,108,131$, and 136, p. 102 ) indicate that the amount of dissolved solids in Cook Mountain waters varies widely but averages rather high, with sodium bicarbonate, sodium sulphate, and sodium chloride as major constituents. Waters of this character can be used for irrigation only under favorable conditions, good natural drainage being especially important. The sandy soils overlying the lower and middle part of the Cook Mountain formation are best adapted to irrigation with these waters. The clayey and black soils are poorly drained and are not so well adapted. It is important that the crops irrigated should not be too susceptible to injury by salts in the water.

The following precautions should be observed before installing permanent plants for large-scale irrigation with Cook Mountain waters:

1. The water from each water-bearing sand penetrated by the well should be analyzed, and waters of inferior quality should be cased off.

2. Lands that are naturally well drained should be selected for irrigation, and provision should be made to employ farming methods tending to increase the natural drainage.

3. Irrigation should be tried on the land on an experimental scale with the crop which it is desired to produce for a sufficient time to indicate whether the water is suitable for permanent irrigation.

\section{YEGUA FORMATION}

Areal extent.-The Yegua formation crops out in a somewhat irregular belt averaging about 5 miles in width, extending in a north-south direction completely across the east-central part of the county. (See pl. 1.) The lands of the area are used chiefly for stock raising.

The contact of the Yegua with the Cook Mountain shown on plate 1 is essentially the same as that shown by Trowbridge. ${ }^{21}$ It is placed at the point in the section where the sandy glauconitic strata of the Cook Mountain change to more argillaceous strata. A prominent bed of oysters (pl. 12, A) occurring 10 to 45 feet above the actual contact has been traced practically across the county and makes an excellent key horizon for the contact. The contact of the formation with the overlying Jackson formation as here mapped differs from that shown by Trowbridge. The Jackson contains notable amounts of volcanic ash and fragmental igneous rocks, and the lowest stratum of volcanic ash has been taken as marking the contact. This restricts the outcrop area of the Yegua to much narrower limits than those shown by Trowbridge. The formation is apparently conformable on the underlying Cook Mountain formation.

Lithology.-The Yegua formation is composed predominantly of dark-gray, greenish, purplish, and reddish gypsiferous carbonaceous clay and sandy clay. There are minor beds of grayish sandstone and

\footnotetext{
21 Trowbridge, A. C., op. eit. (Bull. 837), pl. 7.
} 
thin beds of concretionary limestone. Oyster reefs are not uncommon, but other fossils have not been observed. A composite columnar section of the formation is shown in figure 6 . It will be seen from this figure that sandstone is a very minor constituent, a condition bearing directly on the water-bearing properties of the formation. A view of typical Yegua strata is shown on plate $12, B$.

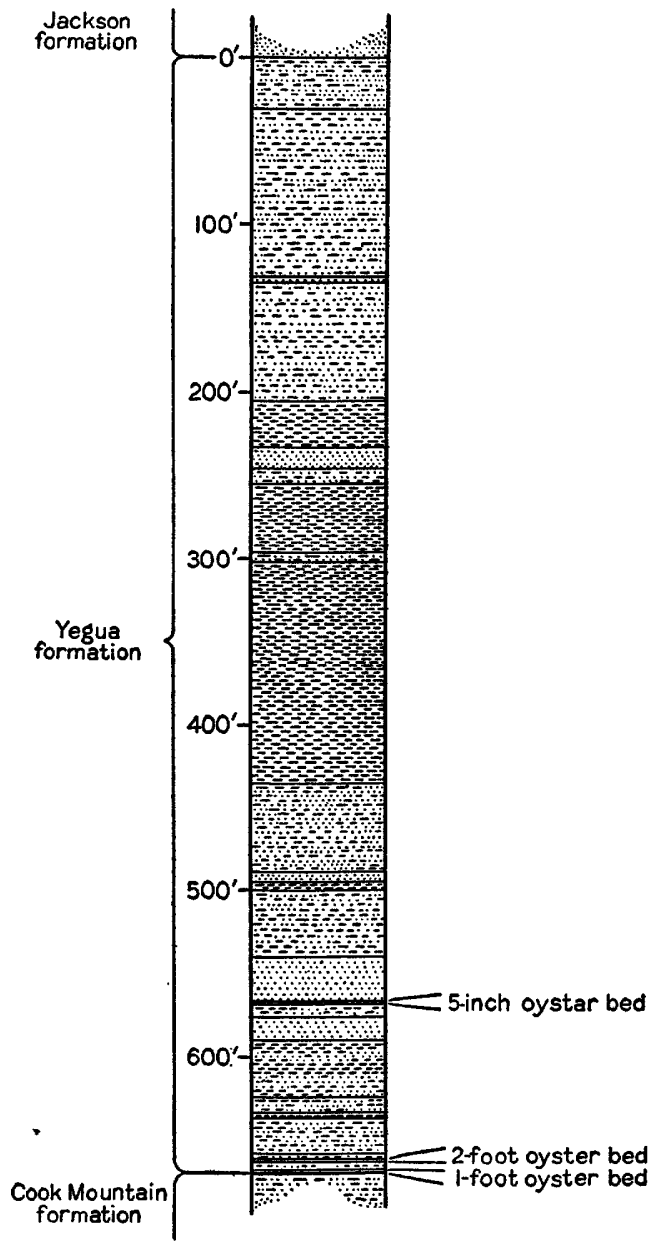

FIGURE 6.-Composite columnar section of the Yegua formation showing predominance of clay.

Thickness and dip.-The thickness of the formation in a section measured along the Corpus Christi-Laredo highway east of Laredo is 670 feet. The dip is about 85 feet to the mile.

Sections.-A section of the Yegua formation measured along the Corpus Christi highway east of Laredo is given below, and a graph of the section is given in figure 6 . 
Section along Corpus Christi highway east of Laredo between points 8.1 miles and 4.3 miles east of Chacon Creek

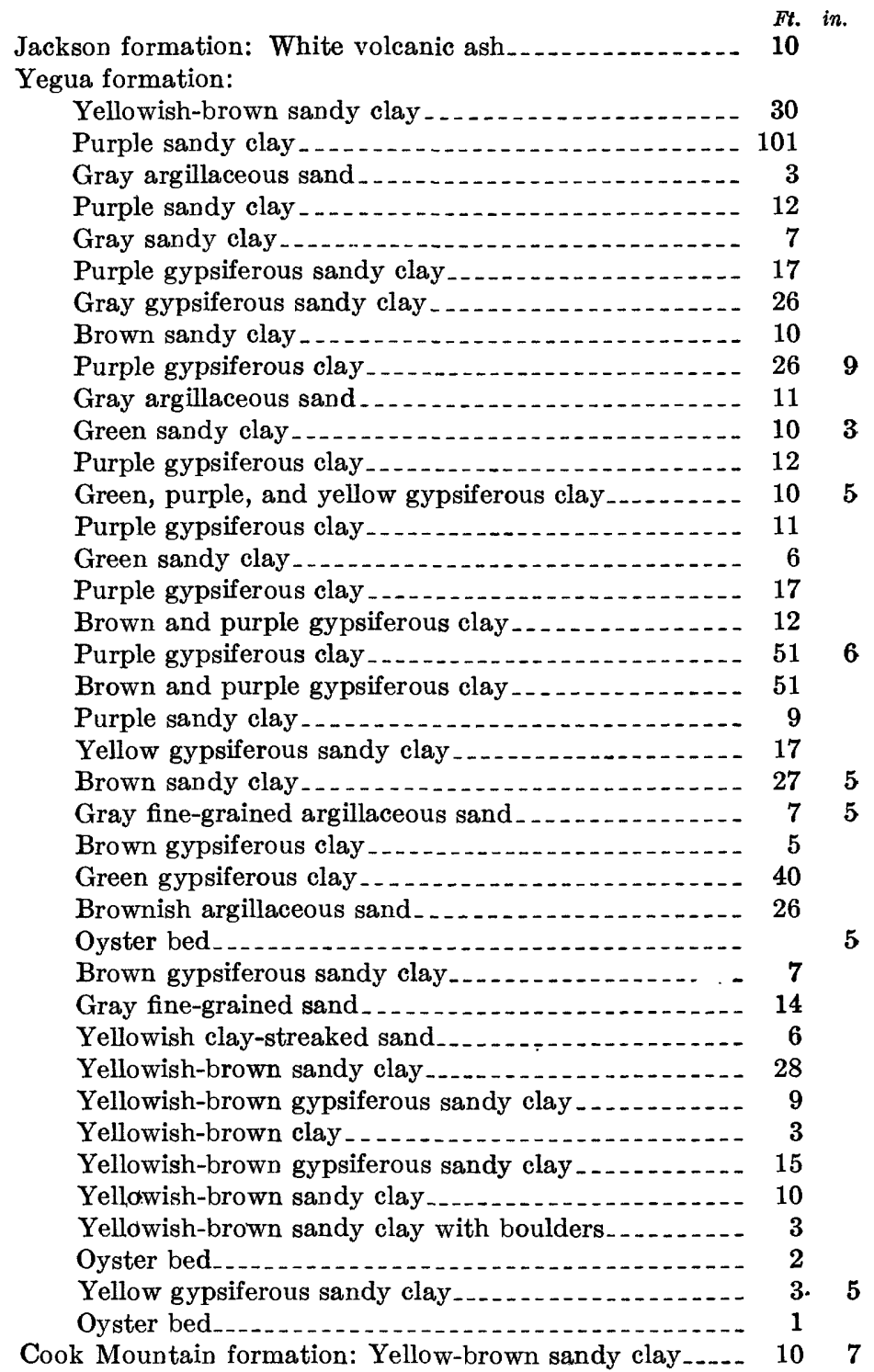

Sections of the base of the formation are found at several places. These show sand, sandy clay, and the oyster bed already mentioned 
and in many places a thin bed of concretionary yellow limestone. One of these sections that is probably typical is given below:

Section of Yegua formation on road 5.2 miles northwest of Callaghan ranch

$\begin{array}{ll}\text { Yellow sandy gypsiferous clay } & \begin{array}{c}\text { Feet } \\ \text { Oyster bed with concretionary limestone.2. }\end{array} \\ \text { Laminated gray gypsiferous clay } & 6 \\ \text { Lignitic chocolate-brown gypsiferous clay } & 2 \\ \text { Green clay } & \end{array}$

Exposures of the upper contact are rare. Generally the overlying sandstone or volcanic ash of the Jackson formation forms a low cuesta, beneath which is a low area with purplish and grayish soil evidently derived from the weathering of clay. Exposures are scanty and invariably consist of clay or sandy clay.

Water supply.-There is very little sandstone in the Yegua formation, and the beds are generally gypsiferous. The prospects of obtaining potable water in the formation are therefore practically negligible. Wells 95 and 97 are thought to obtain water from the Yegua. Both yield salty water which livestock will drink.

In the outcrop area of the Yegua water of fair quality can usually be obtained by drilling through the formation into the underlying Cook Mountain formation. However, some of the beds in the Cook Mountain in this area yield poor water. The depth to the Cook Mountain sands in this area ranges from 200 to 1,000 feet.

\section{JACKSON FORMATION}

Areal extent.-The Jackson formation crops out in a belt 15 to 17 miles wide extending in a north-south direction across the eastern part of the county (pl. 1). Its lower boundary is marked by a bed of volcanic ash or ashy sandstone, which usually forms a distinct though small escarpment or cuesta. The upper boundary or contact with the Frio clay is placed at the point in the section where the more sandy Jackson strata give way to strata with few sandstone beds, few or no ash beds, and no fossils. Both the upper and lower contacts shown on plate 1 differ greatly from those shown by Trowbridge, ${ }^{22}$ as he included parts of the Jackson and Frio of this report in his Yegua and Fayette. The Jackson is conformable with both the Yegua formation and the Frio clay.

The outcrop area of the Jackson formation comprises about 750 square miles, devoted almost completely to ranching with only a few small farms. Part of the area consists of open prairie land, especially in the northern part, but much of it is covered with dense chaparral. A rolling topography is characteristic.

Lithology.-The Jackson formation consists of grayish-green and buff clay, gray and buff sandy clay, buff and light-grayish sandstone,

${ }_{22}$ Trowbridge, A. C., op. cit. (Bull. 837), pl. 7. 



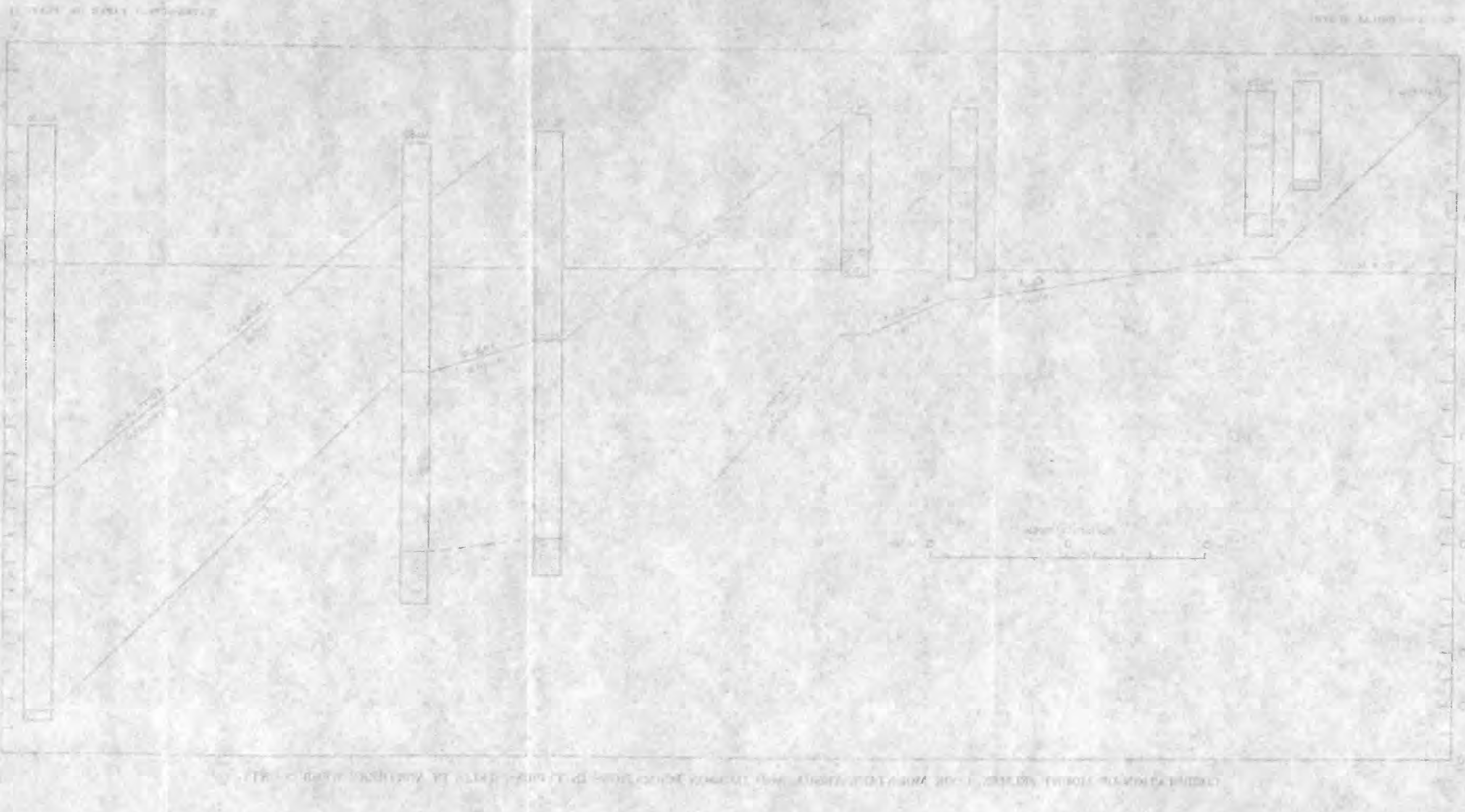




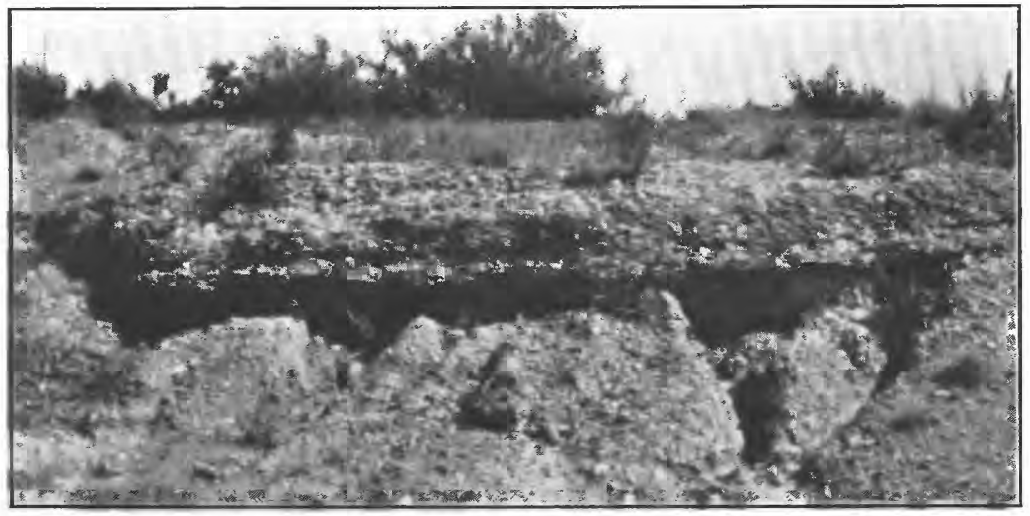

A. OYSTER BED AND CLAY NEAR BASE OF YEGUA FORMATION 7.5 MILES EAST OF LAREDO POST OFFICE.

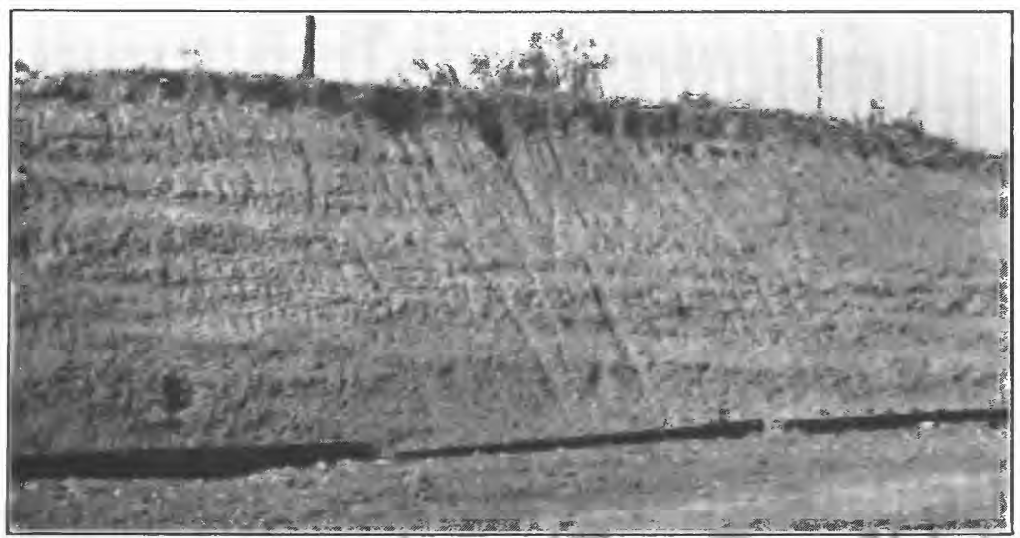

B. TYPICAL YEGUA CLAY 8.7 MILES EAST OF LAREDO POST OFFICE. 

light-gray and white ashy sandstone, and light-gray and white volcanic ash or partly hydrated ash. (See pl. 3, B.) Limestone concretions are not uncommon, and opalized and silicified wood is abundant.

The sandstone is medium-grained, generally micaceous, and usually contains a whitish bentonitic or ashy clay matrix. Minerals probably derived from igneous rocks, such as feldspars, amphiboles, and pyroxenes, are common, so that some of the sandstone is arkose. Beds more than a few feet thick are not observed in the exposures, and the total amount of sandstone is a small part of the whole formation. Many of the sandstone beds are fossiliferous.

Much of the clay is bentonitic and grades into the ashy sandstone. Greenish and buff colors are common on fresh exposures, but weathered surfaces or soils are often purplish. Oyster beds are found here and there in the clay.

Two occurrences of a type of rock unusual in the formation have been found in section 2063,11 miles east slightly south of the Callaghan ranch, and in section 1433, 6 miles northeast of the Callaghan-Junco ranch. The rock is very fine grained, massive, dark gray, and partly chalcedonized. Under the microscope it shows a variety of mineral grains, including feldspars and hornblende in a matrix of silica and calcite. These rocks possibly occur as veins or dikes, but the evidence at the exposures is not conclusive.

Thickness and dip.-The thickness of the Jackson is estimated to be about 1,500 feet. The dip is about 80 feet to the mile.

Sections.-A section showing the contact of the Jackson and Yegua formations has been given in the discussion of the Yegua. In general, exposures along the contact of the two formations are rare. The ash stratum marking the contact in the section mentioned above can be traced only a few miles in either direction. South of this point the contact shows ashy sandstone overlying clay, and in many places the contact is obscured by wind-blown sand. To the north the contact is marked by a slight but distinct escarpment, along which are scattered outcrops of sandstone, clay, and ashy sandstone, with only rarely thin ash beds.

A section of the contact is exposed 2 miles southeast of the Callaghan ranch. Here the escarpment shows 1 foot of sandstone, underlain by 10 feet of clay and 3 feet of ash. A section about 100 feet above the base of the Jackson is exposed 4.6 miles northeast of the CallaghanBecerra ranch and consists of 6 feet of massive coarse gray sandstone with borings and tubes overlying brownish gypsiferous clay. The same sandstone crops out $1 \frac{1}{2}$ miles north of the point in sec. 1334 .

Small sections showing the strata in the middle part of the formation are exposed in many places. Much of the middle part is composed of clay, and the sandy strata are thin or soft and nonresistant. Exposures of a few feet of sandstone, ashy sandstone, and clay are found northeast and east of the Callaghan ranch, in secs. 1333, 1335, 35, 1814, 
and 252 and at the Volpe ranch. In the central and southern parts of the county similar exposures occur in sec. 1744. South of the Texas Mexican Railway the exposures are much the same as those already mentioned. One of the best found is at the Muraya ranch, where the section exposed shows 3 to 5 feet of ashy biotite-bearing sandstone overlying 20 feet of bentonitic brown and green clay and 7 to 10 feet of sandy gypsiferous clay with thin sandstone lenses. A section 1.2 miles south of the Corpus Christi highway, on Retama Creek, shows 8 to 10 feet of thin-bedded sandstone exposed in a fault previously mentioned and shown on plate $3, B$. An abandoned clay pit south of the Corpus Christi highway near Reiser shows a maximum of 12 feet of grayish-green compact gypsiferous clay that weathers yellow. It contains yellowish-gray septarian limestone concretions 1 foot in diameter. Oysters and silicified wood not in place were also observed at this locality.

Section of Jackson formation east of road $1 \frac{1}{2}$ miles north of Yates caliche ranch

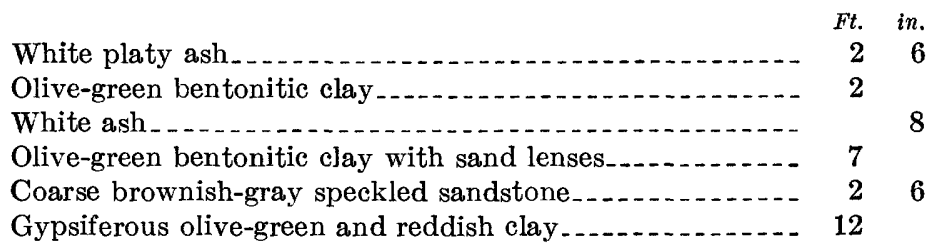

A section near the one given above was measured by Bailey ${ }^{23}$ and tentatively assigned to the fGueydan ${ }^{24}$ (Catahoula tuff) with the qualification that the strata exposed might be Fayette (of Jackson age). There appears no question now that the section given by Bailey and the foregoing section belong to the Jackson formation. Both are in the strike of an extensive section of ash, sandstone, and clay from which plant fossils of Jackson age have been collected. ${ }^{25}$ Bailey's section is repeated below:

\section{Section of bluff in sec. 853, Webb County, 18 miles north of Mirando City}

Lamellar, somewhat sandy fine-textured nonvesicular white Ft. in. trachyte (?) tuff. This rock has a slaty appearance produced by a set of low-angle joint fractures, which cut the bedding planes at slight angles. Vertical rectangular jointing is also well developed........................

\footnotetext{
${ }^{23}$ Bailey, T. L., op. cit., p. 79.

24 A dagger ( $\dagger$ ) preceding a geologic name indicates that the name has been abandoned or rejected for use in classification in publications of the Geological survey. Quotation marks, formerly used to indicate abandoned or rejected names, are now used only in the ordinary sense.

${ }^{25}$ Ball, O. M., personal communication. Dr. Ball states that plant fossils from this locality submitted to him by geologists of the Magnolia Petroleum Co. are of Fayette age.
} 
Section of bluff in sec. 853, Webb County, 18 miles north of Mirando City-Contd.

Creamy to greenish-gray, very gypsiferous soft plastic

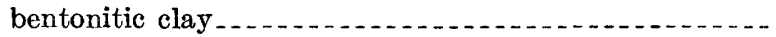

White or creamy-white platy-bedded friable, somewhat vesicular tuff

Ft. in.

26

16

Massive, closely jointed greenish-gray gypsiferous, somewhat sandy clay containing a few horizontal streaks with a pinkish color. Becomes predominantly pink near the base

Very irregularly bedded and lenticular, somewhat plicated light-gray friable medium-grained sandstone which is darker gray on exposed surfaces. This bed shows a few minor crumplings. It is cut by many thin selenite veins, especially along bedding planes. Some satin spar is present in vertical lines.

Rather massive pinkish-gray soft argillaceous sandstone or sandy clay. This sandstone becomes sun-cracked on exposure, like clay. Contains many seams of selenite along bedding and vertical joint planes. Base not exposed

Outcrops believed to be a part of the section characterized by ash or ashy sandstone mentioned above are found both north and south of the sections given. To the north such outcrops occur near the Trammel ranch, in sec. 864 ; near the Puertocito ranch, in sec. 1976; $3 \frac{1}{2}$ miles east of the Las Pintas ranch, in sec. 423 ; and near the old Adami ranch ruins, in sec. 16 . To the south scattered exposures of the material are found nearly to Aguilares. South of Aguilares the continuation of this ash section is not plain, and ash exposures are not so abundant. It is possible that ash exposures in secs. 596 and 736 belong at this horizon, and ashy sandstone is exposed in the García pasture, 5 miles southwest of the outcrop in sec. 736 . The ash zone is prominently exposed again in northern Zapata County.

A section in the Moguellitos Hills, in the northern part of Webb County, is given below. This is very similar to the sections containing ash already described but is several hundred feet lower, being approximately in the middle of the formation. Only a few small exposures of impure ashy material have been found along the strike of this section.

Section of Jackson formation on east side of Moguellitos Hills, in northeastern Webb County

$\begin{array}{lrr}\text { White harsh fine-grained leaf-bearing ash } & \text { Ft. } & \text { in. } \\ \text { Olive-green gypsiferous clay } & & \\ \text { Platy dull brownish-gray fine to medium ashy sandstone_-. } & & \\ \text { Olive-green gypsiferous clay, to bottom } & 9\end{array}$

Sections at the upper contact of the Jackson formation are rarely exposed. The contact is marked by a change from sandy clay and 
sandstone of the Jackson to clay of the Frio formation. The contact passes through a region in which many of the hills are covered with Uvalde gravel, so that exposures are rare and only a few feet in thickness. At the ruins of the old Adami ranch, in sec. 16, in the northeastern part of the county, 6 to 8 feet of thin-bedded ashy sandstone and clay is exposed. This section, however, is probably 150 feet below the top of the Jackson. In sec. 491, on Prieto Creek, 2 feet of platy sandstone is exposed. Fossils have been reported from this locality, ${ }^{20}$ but none were found during the present investigation.

Water supply. - The Jackson formation does not yield good water in Webb County, and in its outcrop area storm-water reservoirs or tanks are largely depended upon to furnish water. A number of wells have been drilled for water in the Jackson, but these yield only small amounts of salt water-for example, wells 90,135 , and 136 . It is reported that a well drilled into the Jackson near the Neal ranch, north of Aguilares, supplied good water. However, the well was lost through caving, and this report cannot be verified.

The Jackson formation holds little or no promise as a source of potable water in Webb County. Its unsuitability as an aquifer is probably due largely to the large amount of clay in the strata and to the fact that the sands are bentonitic and relatively impermeable. In the western part of the outcrop area wells drilled to sandstones of the Cook Mountain formation yield water for stock. In the eastern part of the area the sandstones of the Cook Mountain formation lie at depths of about 2,000 feet, and it is problematic whether or not the water a vailable in them is satisfactory either in quality or in quantity.

\section{OLMGOCENE (?) SERIES}

FRIO CLAY

Nomenclature.- There bas been considerable discussion recently of the nomenclature and correlation of the Frio clay and the formations immediately overlying it. This matter has been summarized by Trowbridge, ${ }^{27}$ who shows that the usage of the term "Frio" has varied from time to time. Originally the term included all the strata in southwestern Texas overlying the Fayette sandstone and underlying the Oakville sandstone. Later, through the work of Bailey, ${ }^{28}$ the original Frio was divided into a lower nonvolcanic unit, which he called "Frio clay", and an upper volcanic unit, which he called the †"Gueydan formation." The geologic map of Texas issued by the Geological Survey in 1937 follows the divisions made by Bailey except that the upper volcanic unit is named "Catahoula tuff." This usage is followed in the present report. The Frio clay, accordingly, is a series of essentially nonvolcanic clay strata overlying the Jackson formation and underlying the Catahoula tuff.

${ }^{26}$ Banks, T. W., personal communication.

27 Trowbridge, A. C., op. cit. (Bull. 837), pp 156-159.

${ }^{28}$ Bailey, T. L., op. cit., pp. 42-52. 
Areal extent.-The Frio clay crops out in a belt in eastern Webb County extending southwestward from the northeast corner of the county to a point about 14 miles west of the southeast corner of the county (pl. 1). The outcrop is about 12 miles wide in the northeastern part of the county and gradually narrows to a width of about $1 \frac{1}{2}$ miles in the southern part. The variation in width is probably the result of an overlap of the formation by the overlying Cataboula tuff. On plate 1 the contacts of the Frio clay with the Jackson formation and Catahoula tuff are shown by dotted lines, indicating that the boundaries have been located only approximately. An unconformity between the Frio and Catahoula is recognized in Duval County, but in Webb County there is no easily distinguishable break between the formations, and exposures are rare. Furthermore, much of the outcrop area is covered with dense chaparral, which makes observations difficult. The area is devoted entirely to ranching.

Lithology.-The formation consists of clay of various colors, but green, yellow, and pink are most common. Sandy clay is present to a moderate extent. Some of the clay appears to be bentonitic, but as a group the clays are distinctly nonvolcanic in character. Gypsum and small calcareous concretions are common. The formation is not fossiliferous.

Thickness and dip.-No accurate measurements of the Frio clay in Webb County are available. In parts of the county estimates based on the width of the outcrop area and sections in wells place the thickness at about 250 feet. In the southern part of the county the formation is apparently overlapped, and the thickness is less than 250 feet. In the northern part of the outcrop area the thickness may be considerably greater than 250 feet. The dip is about 80 feet to the mile.

Sections.-Because of the soft nature of the Frio strata few exposures are found. Road cuts and ravines show rare small exposures of a few feet. Sections of this kind are found $9 \frac{1}{2}$ to 10 miles north of Oilton, in sec. 10. Here exposures of 3 to 5 feet of greenish or olive-green clay are shown in ditches. Similar exposures are found 400 yards southeast of the Yeager ranch house. Throughout the outcrop area excavations made for storm-water reservoirs or tanks generally expose fresh gray-green or pinkish clay. In general, the outcrop area is marked by clayey soils and the absence of hard rocks.

Water supply.-The Frio clay is not known to yield water in Webb County. So far as known no wells have been obtained in the formation, and the predominance of clay strata is believed to preclude the possibility of its supplying water to wells. 


\section{MIOCENE (?) SERIES}

CATAHOULA TUFF

Nomenclature.-The relation of the Catahoula tuff to the Frio clay is discussed on page 62. The Catahoula by definition comprises the volcanic strata underlying the Oakville sandstone and overlying the nonvolcanic Frio clay. This group of strata was called by Bailey the †Gueydan formation, with members called Fant, Soledad, and Chusa. Bailey recognized that his $\dagger$ Gueydan, or at least part of it, was equivalent to the Catahoula sandstone of eastern Texas. More detailed work in recent years has yielded additional evidence on the correlation of the two formations, so that at present the equivalence of the Catahoula sandstone and Bailey's fGueydan is generally accepted. The geologic map of Texas, issued by the Geological Survey in 1937, maps the strata in question as Catahoula tuff, the time equivalent of the Catahoula sandstone. This usage is followed in the present report.

In the present report the members of the Catahoula tuff are not mapped separately. It is thought that strata belonging to the Fant tuff member and Soledad volcanic conglomerate member are present in Webb County and that no strata of the Chusa tuff member are present. The separation of these members, however, has little bearing on the problems of underground water supply.

Areal extent.-The Catahoula tuff crops out in a belt flanking the Bordas escarpment on the west, northwest, and north. The width of the outcrop belt ranges from a fraction of a mile in the southern part of the county to 17 miles along the east county line (pl. 1). The contact of the formation with the underlying Frio clay is shown on plate 1 as a dotted line, indicating that the boundary is only approximately located. The contact with the overlying Goliad sand is the very irregular line of the Bordas escarpment, the upper part of which is essentially the contact between the two formations. It is probable that in the southern part of the outcrop area the Catahoula tuff is overlapped by the Goliad sand, which would account for the narrowness of the belt of outcrop near the south county line. Furthermore, as the Goliad overlaps the Oakville sandstone, the Catahoula is in contact with the Goliad rather than the Oakville in the exposed sections in Webb County.

The outcrop area of the formation is one of rolling topography, covered generally by dense chaparral. A few prominent hills or ridges are due to resistant sandstone. Numerous spurs and low points in front of the main Bordas escarpment are composed of such material and owe their origin to its presence. The outcrop area is devoted entirely to ranching.

Bailey believed that strata belonging to the Oakville sandstone are present along the face of the Bordas escarpment, and he has shown 
these on his map. In the present report the rocks so mapped are referred partly to the Catahoula and partly to the Goliad. So far as known, Oakville strata do not crop out in Webb County, though it must be admitted that the correlation of certain sandstone and conglomerate strata along the Bordas escarpment is a difficult matter and that possibly the correlations used in the present report are not final. Trowbridge considered that exposures of silicified sandstone and conglomerate near Mirando City belong to the Oakville. In the present report these are held to be silicified Catahoula tuffaceous sandstone, silicified Goliad sandstone, and chalcedonic plugs and dikes.

Lithology.-The Catahoula tuff, as the name implies, is composed predominantly of pyroclastic rocks. These include tuffaceous sandstone and conglomerate, whitish tuff, grayish and pinkish silicified tuff, and purplish and greenish bentonitic clay. Nonvolcanic sandstone and clay are present to a minor extent.

Bailey ${ }^{29}$ divided his $\nmid$ Gueydan formation on lithologic grounds into three members, from bottom to top as follows:

Fant tuff (characterized by mud flows).

Soledad volcanic conglomerate sandstone and tuff.

Chusa argillaceous tuff and tuffaceous clay.

As Bailey has shown, the lithology of these members varies considerably along the strike, and it is not practicable to separate them in Webb County. It is believed that only rocks of the Fant and Soledad are present in Webb County and that it is better to speak of these rocks as corresponding in lithology to those of the type Fant or Soledad rather than as belonging specifically to those members.

In Webb County probably the most abundant Catahoula rocks are light-colored tuff, bentonitic tuff, and bentonitic clay. These rocks are not greatly different from the ashy members of the Jackson formation. In weathering they produce pinkish and grayish soils and generally a topography of little relief. Crusts and veinlets of opal or silica are common, and in a few exposures the tuff is completely silicified to a chertlike green or pinkish porcellanite. There is a complete gradation between the types mentioned.

Sandstone and tuffaceous sandstone are locally prominent in the formation and are sufficiently abundant to yield water. These rocks vary greatly in character from place to place, and there is a gradation from the sandy into tuffaceous fine-grained material. Here and there the sandstone occurs in beds 25 feet thick, massive, cross-bedded, and firmly cemented. The most common type of this sort is buff coarsegrained sandstone with varicolored grains and a prominent ash or bentonitic matrix. Exposures of rock of this kind are found on the Bordas escarpment directly south of the Dos Hermanos Hills and on the ridge southeast of the Gates ranch. Some samples from these

" Balley, T. L., op. cit., p. 65. 
localities are conglomeratic, but not so coarse as the conglomerates described from the Soledad Hills. ${ }^{30}$ Individual beds of the sandstone are traceable only a few miles and appear to be lenses in the finergrained tuff and clay of the formation. In many localities less coherent sandy strata are present. These are generally of low porosity, owing to the presence of a prominent fine ashy or clay matrix.

Thickness and dip.-The maximum thickness of Catahoula tuff exposed in Webb County is placed at 750 feet and is found in the area north of Moglia. In the southern part of the outcrop area, where the formation is overlapped, the thickness exposed does not exceed 100 feet. In wells in the eastern part of the county the thickness of the formation probably exceeds 1,000 feet, although because of the similarity to the Frio and Jackson strata it is difficult to assign the formation limits in wells. The thickness is placed as 935 feet in the log of the Carolina Texas Barnsley No. 2 well, about 7 miles north-northeast of Oilton. (See p. 82.) The dip is about 80 feet to the mile.

Sections.-Many sections of the Catahoula tuff are exposed, but the best ones are found along the face of the Bordas escarpment and in the area north of Moglia. The section at the southern part of the Dos Hermanos Hills, north of Moglia, is given below.

Section at south hill of Dos Hermanos, 21/2 miles north of Moglia

Goliad sand:

Conglomerate cemented with caliche........ 5

Medium-grained light-gray incoherent sandstone....... 3

Catahoula tuff:

Pinkish, white, and chocolate-brown, highly jointed ash, silicified in places and with crusts of opal............ 12

Grayish and greenish ashy clay with ash pebbles, interbedded with brownish to buff tuffaceous sandstone, partly silicified

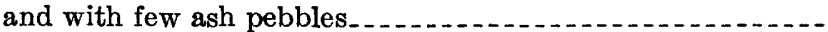

The sandstone beneath the conglomerate near the top of the section was assigned by Bailey to the Oakville but along with similar occurrences is here considered Goliad. The beds classed as Catahoula are probably included in Bailey's Soledad member.

In the area south of Mirando City, where the Bordas escarpment passes out of Webb County, the Goliad and Catahoula are well exposed. In an area of about 4 square miles there are minor differences in the section. A generalized section showing conditions present is given below.

so Bailey, T. L., op. cit., p. 80. 
Generalized section along Bordas escarpment 11 miles south of Mirando City

Goliad sand:

Feet

0-10

White to light-buff sandstone, in part chalcedonized, with palisade weathering .......... 20-25

Silicified gravel conglomerate, grading laterally into sandstone as above. . . . . . . . . . . . . . . .

Catahoula tuff:

Yellowish, buff, and purple clay

Clay and gray to buff medium-grained tuffaceous sandstone

This section, like the preceding one, shows the contact of the Goliad and Catahoula and illustrates the extensive silicification that is common in the Goliad.

A number of good but small exposures are found on the road north from Oilton. In sec. 1012, 0.6 mile north of the pipe line crossing the road, silicified ash with crusts of opal and chalcedony immediately underlies the caliche of the Goliad. One mile north of the pipe line 18 inches of soft friable medium-grained grayish-green sandstone is exposed. The sandstone consists of varicolored grains of several kinds of material, cemented with ash. It is probably of the Soledad type. Small exposures of soft sandstone and tuff are found here and there on the road from Moglia to the Gates ranch, and good exposures of white tuff and grayish tuffaceous clays are present in secs. 56 and 57, southwest of the Gates ranch.

Well sections.-The log of the Carolina Texas Oil Co.'s Barnsley No. 2 well, given on page 82 , covers a complete section of the formation. This log shows a relatively large thickness of sand in beds as much as 25 feet thick alternating with clay and gumbo. The thickness of the Catahoula in this well is placed at 935 feet, but, as stated above, the determination of the exact thickness is difficult.

The logs of seven wells $(141,142,143,169,170,171,178$, and 188) drilled for water in the southeastern part of the county are also given on pages $80,81,82$. None of these wells pass through the Catahoula tuff. The rocks penetrated by the wells consist of alternating beds of sand, clay, and gumbo. The individual sand strata can be correlated only over small areas and apparently are not continuous.

Water supply.-The tuffaceous sandstones constitute the waterbearing beds in the Catahoula. In the outcrop area only a few wells are known to obtain water from the formation, and the water is of variable quality. In this area wells in the Catahoula on the Gates ranch yield salt water suitable for stock, and a well (178) belonging to the Crown Central Petroleum Co. at camp headquarters, south of Mirando City, yields a supply of water sufficient for the domestic use of the camp.

In the area east of the Bordas escarpment the Catahoula yields water to wells 150 to 400 feet deep which pass into it through the 
overlying Goliad sand. Examples are wells 152 to $172,175,176$, 188, and 189. (See pp. 98, 100.) Wells 152 to 167 belong to a battery of 22 wells on the Long tract at Oilton, which are pumped to supply several oil fields, the water being piped as much as 7 miles. Of these wells, 16 are 310 feet deep and may derive water from the Catahoula, while the other 6 (146 to 151) are 75 feet deep and derive water from the overlying Goliad sand. Two water-bearing beds were encountered in these wells-the first at a depth of 75 feet, at the bottom of the Goliad, and the second at a depth of about 300 feet, in the Catahoula, no water of consequence being found between. The wells are pumped from two central power plants, one equipped with a 30-horsepower and the other with a 35-horsepower gas engine, and each well is equipped with an oil-field pump jack and cylinder pump. This battery of wells has been pumped over long periods at the rate of 80,000 gallons a day and is reported to have a capacity of 200,000 gallons a day. The deep wells of the group are said to yield more water than the shallow ones. The static water levels in the deep wells stand at about 125 feet below the surface and in the shallow wells at about 78 feet below the surface. Well 188, in the southernmost part of the area, is 405 feet deep and at the bottom penetrates 25 feet of water sand presumably belonging to the Catahoula. The well supplies water for domestic use and drilling operations to the Magnolia Petroleum Co.'s camp in the Albercas field. The yield of the well was not ascertained. Wells 170,171 , and 172, belonging to the Houston Oil Co., near Bruni, obtain water from the Catahoula, the depth to the top of the principal water-bearing bed in them ranging from 270 to 277 feet. In well 171 a higher sand yielding brackish water was penetrated. The sands in these wells are higher in the geologic section than those in the Oilton area. Well 171 has yielded 336,000 gallons a day under pump, and the other wells can be pumped at essentially the same rate. Well 172 was originally a flowing well, but the static water level in it now stands about 5 feet below the surface.

In the town of Bruni the water supply is derived from well 173 , in the Catahoula tuff. The well is 273 feet deep and originally flowed. The water level in it could not be measured but is reported to be slightly below the surface. The well is pumped at the rate of 12,600 gallons a day, which is probably less than its capacity. Well 174 is one of four wells owned by the Texas Mexican Railway at Bruni. These wells are 231 feet deep and penetrate 6 feet of water sand at the bottom. They originally had a flow of 8 gallons a minute, but now the static water level in them is 44 feet below the surface.

At the tank farm of the Humble Pipe Line Co. southeast of Bruni two wells (175 and 176) draw water from the Catahoula tuff. Well 175 is 365 feet deep and originally had a flow of 25 gallons a minute but now has a flow only when nearby wells are idle and then discharges 
only about 1 gallon a minute. It appears that the water sands in this well are correlative with those encountered in the wells at Bruni and are higher in the geologic section than those encountered in other wells discussed above. Data on additional wells in the Catahoula tuff will be found in the well tables.

Plate 1 shows the approximate boundaries of the area around Bruni in which it is believed that flowing wells can be obtained in the Catahoula. The boundaries are drawn from inadequate data and may be materially in error. The area of flow is smaller than it once was, and it is probable that flows of much volume can be obtained only on very low lands in the valleys.

A consideration of the available data shows that in Webb County the Catahoula tuff will generally yield water to wells. Individual beds of water-bearing sand are not continuous in the formation under wide areas, but in all localities thus far drilled such beds have been encountered. The sands are thin and are not very permeable, but in areas where the formation is overlain by the Goliad sand, which is relatively permeable, considerable water enters it by percolation through the Goliad. Existing wells, however, indicate that usually only moderate amounts of water can be obtained from the Catahoula.

The water from the Catahoula tuff is of variable quality. It generally possesses a slight taste and contains more than 1,000 parts per million of dissolved solids, with sodium carbonate and chloride as major constituents. The water has been used successfully to irrigate grass and small vegetable gardens, but it has been found to be injurious to such plants as roses and strawberries. The Houston Oil Co. has irrigated a tract of citrus trees 3 years with water from the Catahoula, and it appears that the water has possibilities for vegetation of this kind. It must be kept in mind that wells in different localities will yield waters of different characteristics. Analyses of water from wells $145,170,175,178$, and 188 and from one well in the group numbered 152-167 are given in the table on page 102.

All the precautions mentioned in the discussion of Cook Mountain waters should be taken before permanent pumping plants are installed in the Catahoula area. If this is done, it is probable that the least mineralized water yielded by some of the wells in the Catahoula tuff may be successfully used for the irrigation of tracts of a few acres.

\section{PLIOCENE SFRIES}

GOLIAD SAND 21

Outcrop area.-The Goliad sand crops out in southeastern Webb County in the Hebbronville Plain, an area bounded on the west and

${ }_{81}$ This formation is fully defined in Texas Univ. Bull. 3232, pp. 750-761, 782, 1933. 
north by the Bordas escarpment. (See pl. 1 and p. 5.) The plain slopes gently southeastward and is characterized by shallow valleys and red sandy soils. In some places the lands of this area are comparatively open, with only a scattered growth of mesquite, but in others they are covered with dense chaparral.

Lithology.-The Goliad sand includes a considerable variety of rocks. The most common are gray, buff, brown, or red sand, sandstone, silicified sandstone, conglomerate, quartzitic conglomerate, and caliche or secondary limestone. Clay or shale is present in exposures to only a slight extent and is not prominent in logs of wells in the formation.

Thickness and dip.-The thickness of the Goliad sand ranges from 30 to 100 feet, and it is possible that greater thicknesses are present in the extreme eastern part of the county. Along the Bordas escarpment the exposed thickness ranges from 20 to 60 feet. Thicknesses as determined in several wells are given below:

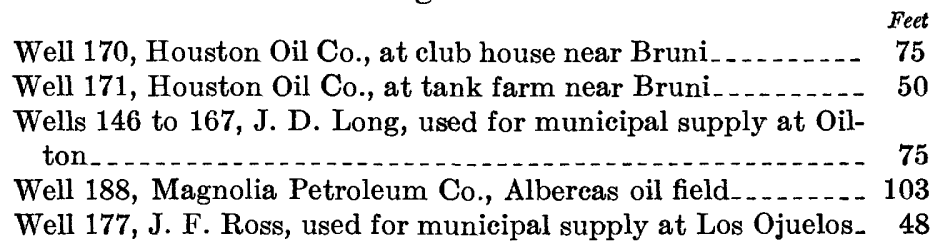

It appears from these figures that the thickness of the formation is variable and that it was deposited on an erosion surface of slight relief.

The dip of the formation is only slightly more than the dip of the slope of the land surface, 10 to 20 feet to the mile.

Sections.- Sections along the Bordas escarpment showing the contact of the Goliad sand and the Catahoula tuff are given on pages 66 and 67. These show the prominence of sand and gravel in the formation and show that the gravel present occurs in lenses grading laterally into sand. The gravel is generally but not invariably near the bottom of the formation.

One of the best sections of the Goliad sand is found at the water plant at Los Ojuelos and is given below.

Section of Goliad sand at Los Ojuelos water plant

Sand with lumps and nodules of ealiche, partly massive, partly
bedded with cross-bedding
Cemented gravel.
Loose sand and gravel.

This section is available because of the unusual type of the water plant, which consists of an inclined shaft to the water-bearing gravel and a horizontal gallery in the gravel. The bottom of the formation is not exposed, but the bottom of the shaft is very near the contact with the underlying Catahoula tuff. 
Caliche

Coarse brownish to buff cross-bedded sandstone with ca-

liche cement.

Fine white caliche

Green clay, weathering pink

The clay or shale in the bottom of this section is tentatively referred to the Goliad, but possibly it is a clay bed in the Catahoula. The question of the presence of the Lagarto and other unexposed formations beneath the Goliad is discussed on page 10 .

Additional exposures of the formation are found in many places but are only a few feet in thickness. The character is best seen in the well sections discussed below.

Well sections.-Drillers' logs of wells $142,143,169,170,171$, and 188 (see pp. 80, 81, 82) show sections of the Goliad sand. In well 142, near the Bordas escarpment, the upper 54 feet is Goliad. The section contained a bed of caliche 1 foot beneath the surface, but the rest of the section was sand and gravel. The lowest Goliad strata encountered were gravel. Well 143, only a short distance from 142, penetrated a similar Goliad section. Well 169 found 55 feet of Goliad. The upper part of the section corresponds to those already given, but below the upper sand and gravel 45 feet of yellow sticky shale was encountered, probably Catahoula tuff.

Well 170, near Bruni, encountered 6 feet of clay at 41 feet and entered the Catahoula tuff at 75 feet. No gravel was recorded in the well log. Well 171, only a short distance away, shows a different section, encountering gravel at 18 feet and gumbo and shale at 50 feet. The top of the Catahoula tuff is considered to be the red gumbo at 50 feet, which probably corresponds to the pink shale of well 170 . Well 188, in the Albercas field, in the southern part of the outcrop area, encountered 103 feet of Goliad. The section does not show caliche but includes 26 feet of shale at 57 feet.

The well sections cited and reports of well drillers show that the Goliad consists largely of sand and gravel with minor amounts of clay. The gravel is not everywhere present, grading laterally into sand. Secondary limestone is usually but not invariably present. Drillers report that it is seldom found beneath the shallow undrained depressions characteristic of the surface in the Goliad outcrop area. These depressions are thought to be due to solution of the secondary limestone, which has resulted in the formation of a modified karst topography.

Water supply.-Supplies of water sufficient for stock and domestic use are obtainable over most of the outcrop area of the Goliad sand, and in several places rather large supplies have been developed from this formation. The water is generally obtained from beds of gravel and sand near the bottom of the formation at depths of less than $100 \mathrm{feet}$. 
Data relating to numerous wells in the Goliad are shown in the tables of well records and drillers' logs.

Ranch wells usually are pumped with a windmill and yield 2 to 20 gallons a minute. Larger wells with oil-field pumping equipment yield as much as 35 gallons a minute. Wells 179 to 185 best illustrate this type of well and a practice that must be followed to insure large supplies of water. In this installation there are 7 wells of 6 -inch diameter, located in a circle about 100 yards in diameter. The wells are fitted with oil-field 4-inch cylinder pumps, and all are pumped by one 20horsepower engine by the ordinary oil-pumping methods. These wells have been pumped to supply 120,000 gallons of water a week. The yield during the time of pumping is about 35 gallons a minute. There is a similar installation in the eastern part of Oilton, but here most of the wells obtain water from the Catahoula tuff, so that no accurate figures are available on the yield from the Goliad.

Mirando City obtains its water supply from the Goliad sand at a water plant at Los Ojuelos (well 177). Here an inclined shaft was dug to the water level, not far above the top of the Catahoula tuff. The lower part of the shaft is excavated in the gravel and sand containing the water, and leading from the shaft is a drift 150 feet long with a cross section 5 by 4 feet. The water level is 32 feet below the surface, which is about the top of the drift, so that the drift acts as a storage reservoir and also furnishes a large surface for inflow of the water. A power pump with a capacity of 30 gallons a minute is installed a few feet above the water level in the shaft. The plant is operated only as needed to supply Mirando City and nearby field operations. The total consumption is about 900,000 gallons a month. During pumping the water level is drawn down 3 feet, but it returns to the original level when pumping ceases.

The quality of water from the Goliad sand is variable. The water often has a decided taste and in general is somewhat highly mineralized, in some places being too highly mineralized for use. The precautions mentioned in the discussion of Cook Mountain waters should be observed in using these waters for irrigation.

\section{TERTIARY (P) S YSTEM}

\section{PLIOCENE (?) SERIES}

UVALDE GRAVEL

Isolated masses of sand, gravel, and caliche, rather universally distributed over Webb County west of the Bordas escarpment, are here called "Uvalde gravel." These materials are similar to the sand and gravel of the Goliad but are found at considerably lower altitudes and hence are probably younger. They are regarded as being equivalent in age to the high-level gravel near Uvalde.

The Uvalde gravel consists of coarse gravel or gravel and sand, in places cemented with caliche, and occurs as caps of hills. Scattered 
outcrops of essentially pure caliche are also referred to the Uvalde, as they occur in the same topographic position and as this material is generally present as a cement in the exposures of gravel. The isolated occurrences of the Uvalde gravel are only a few feet thick and are not a source of water. They are not shown separately on plate 1 , and only one or two occurrences are discussed below.

One of the best exposures of Uvalde gravel is at Green siding on the Missouri Pacific Railroad north of Laredo, where the sand and gravel have been quarried for construction material. The section shows 20 feet of sand and gravel with caliche cement. The upper part is essentially a limestone conglomerate. Lower in the section are lenses of sand and gravel, conspicuously cross-bedded. Pebbles in the conglomerate beds range from less than 1 inch to 6 inches in diamater.

The Dos Hermanos Hills, on the Espejo ranch in the northwestern part of Webb County, are capped with caliche of considerable variation in density and porosity. Below the caliche is calcareous clay. Trowbridge ${ }^{32}$ considers these occurrences to be spring deposits. The evidence for this is not conclusive, especially when it is considered that the springs must have issued through the underlying thick clay section of the Mount Selman formation. Other hills in the same region show somewhat similar features, and it is doubtful if the origin of these can be assigned to spring deposits.

QUATERNARY SYSTEM

RECENT SERIES

ALLUVIUM

Fine sand, gravel, and silt of recent age have been deposited in the stream valleys of Webb County. Much of the valuable agricultural land near the Rio Grande is of this sort and is used for intensive truck farming. Valleys of the larger streams in the rorthern part of the county, tributary to the Nueces River, also contain alluvial deposits. Prieto Creek is a noteworthy example. In the Rio Grande Valley the alluvial material occurs in terraces, which have been discussed by Trowbridge. ${ }^{33}$

Numerous sections of the alluvial material are exposed along the Rio Grande and range in thickness from a few feet to 100 feet. These usually show fine grayish-brown silt and minor amounts of sand. At a locality near the Central Power \& Light Co.'s transformer station, in the northern part of Laredo, the alluvial material includes beds of gravel that have been quarried for use in construction.

Wells in the alluvium yield small amounts of water. In the Laredo area wells 1 mile from the river pass through 40 feet of alluvium that contains one water sand yielding a very small quantity of salty water.

32 Trowbridge, A. C., op. cit. (Bull. 837), pp. 191-192.

${ }^{33}$ Idem, pp. 219-225. 
In the valley of Prieto Creek, in the northeastern part of the county, the alluvium is about 25 feet thick. Well 134 is 18 feet deep and obtains a small supply of water suitable for domestic use.

Where the Cook Mountain or other aquifers can be reached at moderate depths the alluvium does not constitute the best source of water, but in areas such as the outcrop area of the Jackson formation the alluvium may be the only source of potable underground water. In such areas under favorable conditions it will yield a small amount. The wells, however, should not be drilled into the underlying formations, which yield water unsuitable for domestic use.

\section{MINERAL RESOURCES}

COAL

The coal resources of the Dolores-Santo Tomas area in Webb County have been described in detail by Ashley. ${ }^{34}$ He shows the cannel coal to be of bituminous rank, high in volatile matter, low in moisture, and with a very high percentage of nitrogen. The present work has added detailed mapping of the coal outcrops and sections at various localities. Plate 1 shows that the Santo Tomas coal does not crop out north of Palafox and that the San Pedro coal does not crop out south of Palafox. Since the time of Ashley's report several deep wells have been drilled in the northwestern part of Webb County. These give no evidence of the extension of coal beds into the extreme northern part of the county. It is probable that the statements of Ashley and Dumble ${ }^{35}$ with regard to the extent of the cannel coal beds must be modified.

\section{GRAVEL}

The quarrying operations for gravel at Green siding near Laredo have already been mentioned. The Goliad sand and the Recent deposits afford an abundant supply of this material.

\section{OIL AND GAS}

No attempt is made here to describe the structural and stratigraphic features of the several oil and gas fields of Webb County, which are beyond the scope of this report. The fields are described at some length by Trowbridge, ${ }^{36} \mathrm{McF}$ arland, ${ }^{37}$ and Brace. ${ }^{38}$

\footnotetext{
34 Ashley, G. H., The Santo Tomas cannel coal, Webb County, Tex.: Geol. Survey Bull. 691-I, pp. 251-270, 1919.

${ }_{35}$ Dumble, E. T., Report on the brown coal and lignite of Texas, pp. 188-189, Texas Geol. Survey, 1892.

${ }_{36}$ Trowbridge, A. C., op. cit. (Bull. 837), pp. 237-251.

${ }^{37}$ MeFarland, P. W., Laredo district, Texas: Structure of typical American oil fields, vol. 1, pp. 389-408, 1929.

${ }^{38}$ Brace, O. L., Factors governing accumulation of oil and gas in Miranda and Pettus districts, Gulf Coastal Texas, and their application to other areas: Am. Assoc. Petroleum Geologists Bull., vol. 15, pp. 755-786, 1931.
} 


\section{SUMMARY OF CONCLUSIONS}

In Webb County water supplies can be obtained from the Carrizo sand, Cook Mountain formation, Catahoula tuff, and Goliad sand and locally from valley fill. The Carrizo sand has the greatest potential value as a source of water for irrigation, as well as for domestic use and for stock. Practically everywhere in the region wells in the Carrizo sand yield abundant supplies of good water. In Dimmit County, which adjoins western Webb County on the north, thousands of acres of valuable crops are irrigated with water from this sand. In its outcrop area in Webb County water of good quality is found in wells at depths ranging from 100 to 200 feet. Down the dip to the east wells reach the sand at increasingly greater depths, but it is estimated that water could be economically obtained in the Carrizo from a belt 10 to 12 miles wide paralleling the outcrop. Although a large part of this belt consists of rough land, it contains small areas of tillable land that could be irrigated. Analyses of water from three wells in the Carrizo sand (2, 5, and 14) are given in the table of analyses (p. 102). Wells 2 and 5 are in the outcrop area and are comparatively shallow. Well 14 is east of the outcrop and is 1,425 feet deep.

The sand in the lower part of the Cook Mountain formation is the second most important source of ground water in the county. In the central and eastern parts of the outcrop area and in a narrow belt to the east of the outcrop large quantities of water are obtained from wells in this formation, and some of the water is suitable for irrigation on the sandy soil of parts of these areas. The table of water analyses shows the mineral character of water from nine wells in the county that derive water from the Cook Mountain formation (27, 32, 41, 57, $72 \mathrm{a}, 86,88,108$, and 131 ).

In the outcrop areas of the Catahoula tuff moderate supplies of water of variable quality can be obtained. In the outcrop area of the Goliad sand shallow wells yield moderate supplies of water which is of variable quality but is vsually suitable for domestic use and may be satisfactory for irrigation; and deeper wells, some of which flow from the underlying Catahoula tuff, usually yield rather highly mineralized water. Valley-fill materials yield small quantities of water in some parts of the county.

The water from wells in the Cook Mountain formation and Goliad sand should be tested by chemical analyses or by actual use on an experimental scale over a considerable period of time before costly irrigation works are constructed to make use of them. No good water is obtained from shallow wells in the outcrop areas of the Mount Selman, Yegua, and Jackson formations and the Frio clay. Deep wells sunk through the Jackson to the Cook Mountain formation will yield water that is generally suitable for domestic use and stock.

$105575-37-6$ 
WELL TABLES

Log of William Helweg well, 0.7 mile south of Encinal, west of highway (well 40)

\begin{tabular}{|c|c|c|c|c|c|}
\hline & $\begin{array}{c}\text { Thick- } \\
\text { ness } \\
\text { (feet) }\end{array}$ & $\underset{\text { (feet) }}{\text { Depth }}$ & & $\begin{array}{l}\text { Thick- } \\
\text { ness } \\
\text { (feet) }\end{array}$ & $\begin{array}{l}\text { Depth } \\
\text { (feet) }\end{array}$ \\
\hline $\begin{array}{l}\text { Cook Mountain formation: } \\
\text { Water sand } \\
\text { Blue mud } \\
\text { Blue shale } \\
\text { Water sand } \\
\text { Blue shale } \\
\text { Black rock } \\
\text { Blue shale } \\
\text { Water sand. } \\
\text { Blue shale } \\
\text { Water sand (main sand) }\end{array}$ & $\begin{array}{r}5 \\
85 \\
90 \\
20 \\
30 \\
4 \\
14 \\
37 \\
35 \\
67\end{array}$ & $\begin{array}{r}65 \\
150 \\
240 \\
260 \\
290 \\
294 \\
308 \\
345 \\
380 \\
447\end{array}$ & $\begin{array}{l}\text { Cook Mountain formation-Con. } \\
\text { Blue shale. } \\
\text { Hard rock } \\
\text { Sand } \\
\text { Shale } \\
\text { Blue gumbo } \\
\text { Sand } \\
\text { Gumbo } \\
\text { Sand } \\
\text { Gumbo }\end{array}$ & $\begin{array}{r}18 \\
5 \\
15 \\
16 \\
19 \\
15 \\
28 \\
22 \\
15\end{array}$ & $\begin{array}{l}465 \\
470 \\
485 \\
501 \\
520 \\
535 \\
563 \\
585 \\
600\end{array}$ \\
\hline
\end{tabular}

Partial $\log$ of A. D. J. Oil Co.'s Pratt $2 \mathrm{~B}$ well, on survey 1127, 5.3 miles northwest of Cactus, on George Woodland farm (well 45)

\begin{tabular}{|c|c|c|c|c|c|}
\hline & $\begin{array}{c}\text { Thick- } \\
\text { ness } \\
\text { (feet) }\end{array}$ & $\begin{array}{l}\text { Depth } \\
\text { (feet) }\end{array}$ & & $\begin{array}{c}\text { Thick- } \\
\text { ness } \\
\text { (feet) }\end{array}$ & $\begin{array}{l}\text { Depth } \\
\text { (feet) }\end{array}$ \\
\hline 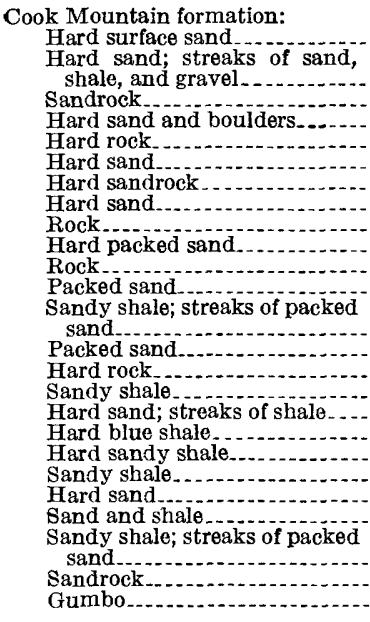 & $\begin{array}{r}30 \\
\\
20 \\
10 \\
10 \\
3 \\
50 \\
3 \\
9 \\
3 \\
12 \\
5 \\
10 \\
\\
15 \\
45 \\
5 \\
10 \\
24 \\
14 \\
6 \\
4 \\
4 \\
10 \\
\\
23 \\
9 \\
4\end{array}$ & $\begin{array}{r}30 \\
\\
50 \\
60 \\
70 \\
73 \\
123 \\
126 \\
135 \\
138 \\
150 \\
155 \\
165 \\
\\
180 \\
225 \\
230 \\
240 \\
264 \\
278 \\
284 \\
288 \\
292 \\
302 \\
\\
325 \\
334 \\
338\end{array}$ & 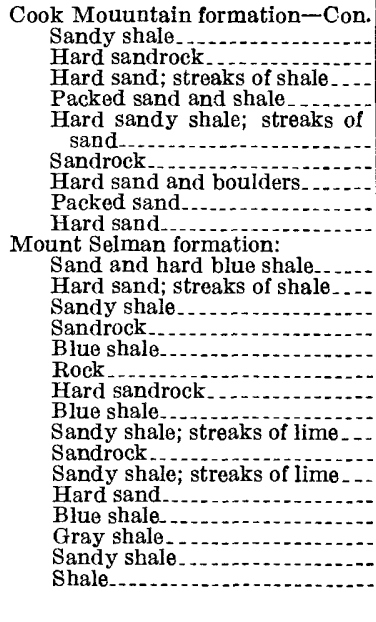 & $\begin{array}{r}10 \\
4 \\
6 \\
8 \\
14 \\
9 \\
9 \\
2 \\
14 \\
4 \\
\\
16 \\
2 \\
7 \\
3 \\
5 \\
3 \\
5 \\
14 \\
11 \\
3 \\
18 \\
8 \\
38 \\
8 \\
6 \\
6\end{array}$ & $\begin{array}{l}348 \\
352 \\
358 \\
366 \\
\\
390 \\
359 \\
391 \\
495 \\
409 \\
\\
425 \\
427 \\
434 \\
437 \\
442 \\
445 \\
450 \\
464 \\
475 \\
478 \\
496 \\
504 \\
542 \\
550 \\
556 \\
562\end{array}$ \\
\hline
\end{tabular}

Log of J. B. Chilton well 2, at San Roman ranch (well 61)

\begin{tabular}{|c|c|c|c|c|c|}
\hline & $\begin{array}{c}\text { Thick- } \\
\text { ness } \\
\text { (feet) }\end{array}$ & $\begin{array}{c}\text { Depth } \\
\text { (feet) }\end{array}$ & & $\begin{array}{c}\text { Thick- } \\
\text { ness } \\
\text { (feet) }\end{array}$ & $\begin{array}{l}\text { Depth } \\
\text { (feet) }\end{array}$ \\
\hline $\begin{array}{l}\text { Cook Mountain formation: } \\
\text { Sandy clay } \\
\text { Blue shale } \\
\text { Water sand; little water } \\
\text { Gray shale } \\
\text { Water sand } \\
\text { Blue shale } \\
\text { Sandy shaie } \\
\text { Blue shale } \\
\text { Water sand } \\
\text { Water sand; shale seams. } \\
\text { Gray shale } \\
\text { Water sand } \\
\text { Sandy shale........... }\end{array}$ & $\begin{array}{r}30 \\
80 \\
10 \\
45 \\
5 \\
20 \\
10 \\
18 \\
17 \\
35 \\
40 \\
20 \\
7\end{array}$ & $\begin{array}{r}30 \\
110 \\
120 \\
165 \\
170 \\
190 \\
200 \\
218 \\
235 \\
270 \\
310 \\
330 \\
337\end{array}$ & $\begin{array}{l}\text { Cook Mountain formation-Con. } \\
\text { Water sand } \\
\text { Gray shale } \\
\text { Brown sandy shale } \\
\text { Water sand; shale seams. } \\
\text { Blue shale } \\
\text { Water sand } \\
\text { Blue shale } \\
\text { Water sand } \\
\text { Gray shale } \\
\text { Green sandy shale } \\
\text { Blue shale } \\
\text { Green sandy shale. }\end{array}$ & $\begin{array}{r}28 \\
25 \\
25 \\
45 \\
18 \\
17 \\
43 \\
12 \\
5 \\
15 \\
15 \\
50\end{array}$ & $\begin{array}{l}365 \\
390 \\
415 \\
460 \\
478 \\
495 \\
538 \\
550 \\
555 \\
570 \\
585 \\
635\end{array}$ \\
\hline
\end{tabular}


I o! of Mantus well of Callaghan Land \& Pastoral Co., 8 miles northeast of ranch headquarters (well 88)

\begin{tabular}{|c|c|c|c|c|c|}
\hline & $\begin{array}{c}\text { Thick- } \\
\text { ness } \\
\text { (feet) }\end{array}$ & $\begin{array}{l}\text { Depth } \\
\text { (feet) }\end{array}$ & & $\begin{array}{c}\text { Thick- } \\
\text { ness } \\
\text { (feet) }\end{array}$ & $\begin{array}{l}\text { Depth } \\
\text { (feet) }\end{array}$ \\
\hline $\begin{array}{l}\text { Yegua formation: } \\
\text { Soil } \\
\text { Red crumbly clay } \\
\text { Red and blue sliale } \\
\text { Red shale. } \\
\text { No record. } \\
\text { Gas show } \\
\text { Hard gray formation; breaks } \\
\text { gumbo } \\
\text { Sand } \\
\text { Shale gumbo and rock }\end{array}$ & $\begin{array}{r}2 \\
18 \\
40 \\
120 \\
100 \\
5 \\
145 \\
20 \\
120\end{array}$ & $\begin{array}{r}2 \\
20 \\
60 \\
180 \\
280 \\
285 \\
430 \\
450 \\
570\end{array}$ & $\begin{array}{l}\text { Yegua formation-Continued. } \\
\text { Hard sandy formation } \\
\text { Hard sand with water. } \\
\text { No record } \\
\text { Shale... } \\
\text { Sand; salt water wa } \\
\text { Shale and gumbo } \\
\text { Cook Mountain formation: } \\
\text { Hard white rock with gas show. } \\
\text { Shale gumbo and boulders.... } \\
\text { Hard sandy formation }\end{array}$ & $\begin{array}{r}20 \\
15 \\
108 \\
37 \\
20 \\
255 \\
\\
10 \\
465 \\
130\end{array}$ & $\begin{array}{r}590 \\
605 \\
713 \\
750 \\
770 \\
1,025 \\
1,035 \\
1,500 \\
1,630\end{array}$ \\
\hline
\end{tabular}

Log of Callaghan Land \& Pastoral Co.'s well 6 $\frac{1}{2}$ miles southeast of Webb (well 96)

\begin{tabular}{|c|c|c|c|c|c|}
\hline & $\begin{array}{c}\text { Thick- } \\
\text { ness } \\
\text { (feet) }\end{array}$ & $\begin{array}{l}\text { Depth } \\
\text { (feet) }\end{array}$ & & $\begin{array}{c}\text { Thick- } \\
\text { ness } \\
\text { (feet) }\end{array}$ & $\begin{array}{l}\text { Depth } \\
\text { (feet) }\end{array}$ \\
\hline 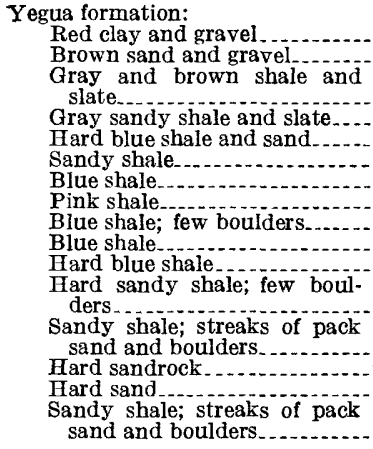 & $\begin{array}{r}34 \\
12 \\
10 \\
25 \\
22 \\
32 \\
18 \\
7 \\
12 \\
36 \\
20 \\
12 \\
22 \\
5 \\
18 \\
31\end{array}$ & $\begin{array}{r}34 \\
46 \\
\\
56 \\
81 \\
103 \\
135 \\
153 \\
160 \\
172 \\
208 \\
228 \\
\\
240 \\
\\
262 \\
267 \\
285 \\
\\
316\end{array}$ & $\begin{array}{l}\text { Yegua formation-Continued. } \\
\text { Hard sandy shale and boulders. } \\
\text { Blue shale } \\
\text { Hard sand } \\
\text { Blue shale. } \\
\text { Hard sandy shale. } \\
\text { Pink shale. } \\
\text { Blue shale } \\
\text { Hard sandy shale } \\
\text { Cook Mountain formation: } \\
\text { Hard sand; streaks of shale } \\
\text { and boulders. } \\
\text { Hard sandy shale. } \\
\text { Pink shale... } \\
\text { Hard sandy shale. } \\
\text { Limerock. } \\
\text { Water sand. }\end{array}$ & $\begin{array}{r}28 \\
20 \\
8 \\
18 \\
12 \\
18 \\
18 \\
9\end{array}$ & $\begin{array}{l}344 \\
364 \\
372 \\
390 \\
402 \\
420 \\
438 \\
447\end{array}$ \\
\hline
\end{tabular}

Log of Callaghan Land \& Pastoral Co.'s well 121/2 miles east of Green siding (well 107)

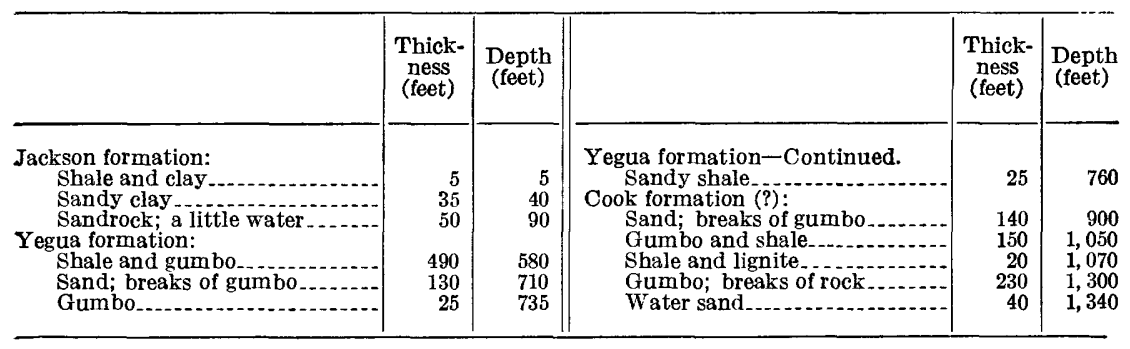


Log of Central Power \& Light Co.'s well on heights, Laredo (well 125)

\begin{tabular}{|c|c|c|c|c|c|}
\hline & $\begin{array}{l}\text { Thick- } \\
\text { ness } \\
\text { (feet) }\end{array}$ & $\begin{array}{l}\text { Depth } \\
\text { (feet) }\end{array}$ & & $\begin{array}{l}\text { Thick- } \\
\text { ness } \\
\text { (feet) }\end{array}$ & $\begin{array}{l}\text { Depth } \\
\text { (feet) }\end{array}$ \\
\hline $\begin{array}{l}\text { Cook Mountain formatio } \\
\text { Surface gravel and sol }\end{array}$ & & & Mount Selman formatio & & \\
\hline $\begin{array}{l}\text { Surface gravel and so } \\
\text { Rock }\end{array}$ & $\begin{array}{r}6 \\
23\end{array}$ & $\begin{array}{r}6 \\
29\end{array}$ & $\begin{array}{l}\text { Packed sand } \\
\text { Slate and shale }\end{array}$ & $\begin{array}{r}25 \\
7\end{array}$ & $\begin{array}{l}1,658 \\
1,665\end{array}$ \\
\hline Shale.............. & $\begin{array}{r}20 \\
4\end{array}$ & 33 & Hard sand and lignit & 10 & $\begin{array}{l}1,000 \\
1,675\end{array}$ \\
\hline Rock & 9 & 42 & Hard shale....... & 31 & 1,706 \\
\hline Flint rock. & 1 & 43 & Shale and sandstone & 59 & 1,765 \\
\hline Rock........... & 6 & 49 & Packed sand........ & 47 & 1,812 \\
\hline Fine red sand & 3 & 52 & Hard shale & 22 & 1,834 \\
\hline Sandstone and sha & 25 & 77 & Sandy shale.- & 12 & 1,846 \\
\hline Sandstone.......... & 79 & 156 & Packed sand and sha & 63 & 1,909 \\
\hline Hard rock & 1 & 157 & Shale, sand, and lime. & 28 & 1,937 \\
\hline Sandstone & 16 & 173 & Packed sand & 10 & 1,947 \\
\hline Hard packed sand; & & & Shale........ & 5 & 1,952 \\
\hline traces" & 15 & 188 & Packed sand & 38 & 1,990 \\
\hline Packed sand. & 47 & 235 & Shale, sand, and lim & 49 & 2,039 \\
\hline Packed sand; shale & 17 & 252 & Packed sand....... & 32 & 2,071 \\
\hline Sandstone...... & 14 & 266 & Hard shale..... & 7 & 2,078 \\
\hline Shale..... & 4 & 270 & Hard shale, packed s & & \\
\hline Packed sand & 8 & 278 & lime................ & 35 & 2,113 \\
\hline Mount Selman formatio & & & Carrizo sand(?): & & \\
\hline Hard shale and pack & 47 & 325 & Packed sand. & 72 & 2,185 \\
\hline Fine sand. & 6 & 331 & Slaty shale and lime & 14 & 2,199 \\
\hline Hard shale and pacl & 94 & 425 & Packed sand........... & 12 & 2,211 \\
\hline Shale...... & 23 & 448 & Sandstone.... & 5 & 2,216 \\
\hline Fine sand. & 8 & 456 & Packed sand.-. & 16 & 2,232 \\
\hline Hard packed sand & 36 & 492 & Iron ore and pyrite. & 4 & 2,236 \\
\hline $\mathrm{Sh}$ & 14 & 506 & Hard sandstone..... & 7 & 2,243 \\
\hline Hard shale and pack & 18 & 524 & Packed sand . & 43 & 2,286 \\
\hline Sandstone & 2 & 526 & Shale and sand. & 23 & 2,309 \\
\hline Hard & 18 & 544 & Indio formation (?): & & \\
\hline $\mathrm{Pa}$ & 16 & 560 & Hard shale and lime & 34 & 2,343 \\
\hline Shale... & 83 & 643 & Packed sand. & 12 & 2,355 \\
\hline Packed sa & 32 & 675 & Hard shale . & 8 & 2,363 \\
\hline Shal & 15 & 690 & Packed sand. & 21 & 2,384 \\
\hline Packed sand. & 10 & 700 & Hard shale and packe & 60 & 2,444 \\
\hline Shal & 160 & 860 & Hard sandstone & 3 & 2,447 \\
\hline So & 10 & 870 & ind.. & 8 & 2,455 \\
\hline Limestor & 20 & 890 & Hard shale and sand & 30 & 2,485 \\
\hline Sh & 24 & 914 & ced sand... & 8 & 2,493 \\
\hline $\mathrm{Sh}$ & 22 & 936 & Hard shale and packe & 15 & 2,508 \\
\hline Soft & 15 & 951 & Packed sand ......... & 22 & 2,530 \\
\hline Hard & 19 & 970 & Shale..... & 10 & 2,540 \\
\hline & 6 & 976 & Hard packed & 41 & 2,581 \\
\hline le.. & 98 & 1,074 & hale or lig & 12 & 2,593 \\
\hline $\mathrm{L}$ & 5 & 1,079 & and ... & 23 & 2,616 \\
\hline $\mathrm{H}$ & 6 & i, 085 & Packed s & 15 & 2,631 \\
\hline Shale & 62 & 1,147 & ed sand & 24 & 2,655 \\
\hline & 8 & 1,155 & nd, "wet", & 17 & 2,672 \\
\hline $\mathrm{H}$ & 67 & 1,222 & and & 15 & 2,687 \\
\hline Hard blue & 31 & 1,253 & Shale and lime. & 6 & 2,693 \\
\hline & 22 & 1,275 & d sand. & 10 & 2,703 \\
\hline & 75 & 1,350 & Hard slaty shale & 40 & 2,743 \\
\hline Shale with lim & 13 & 1,363 & Shale and lime....... & 22 & 2,765 \\
\hline $\mathrm{Hz}$ & 55 & 1,418 & Sar & 11 & 2,776 \\
\hline Har & 24 & 1,442 & Broken sand and shal & 54 & 2,830 \\
\hline Har & 14 & 1,456 & Hard shale. & 23 & $\begin{array}{l}2,800 \\
2,853\end{array}$ \\
\hline $\mathrm{Pa}$ & 5 & 1,461 & Shale and sand streaks & 26 & 2,879 \\
\hline Hard & 14 & 1,475 & Hard sand & 10 & 2889 \\
\hline d shale & 15 & 1,490 & Sand; shale streaks & 36 & 2,925 \\
\hline Slate and shale...- & 70 & 1,560 & Sticky shale and boulders & 29 & 2,954 \\
\hline Shale and limestone & 19 & 1,579 & Hard sand & 9 & 2,963 \\
\hline Shale.... & 24 & 1,603 & Hard sand and shale & 35 & 2,998 \\
\hline Hard pack & 20 & 1,623 & Hard shale & 76 & 3,074 \\
\hline Loose sand............ & 10 & 1,633 & & & \\
\hline
\end{tabular}

Log of C. E. Richter well, 21/2 miles southeast of Laredo, west of Zapata highway (well 129)

\begin{tabular}{|c|c|c|c|c|c|}
\hline & $\begin{array}{c}\text { Thick- } \\
\text { ness } \\
\text { (feet) }\end{array}$ & $\begin{array}{l}\text { Depth } \\
\text { (feet) }\end{array}$ & & $\begin{array}{c}\text { Thick- } \\
\text { ness } \\
\text { (feet) }\end{array}$ & $\begin{array}{l}\text { Depth } \\
\text { (feet) }\end{array}$ \\
\hline $\begin{array}{l}\text { Cook Mountain formation: } \\
\text { Red soil }\end{array}$ & & & $\begin{array}{l}\text { Cook Mountain formation-Con. } \\
\text { Blue marl }\end{array}$ & & \\
\hline Yellow sandy clay & 72 & 80 & Brown gumbo & 25 & 270 \\
\hline Blue limestone rock; little & 5 & 85 & $\begin{array}{l}\text { Water sand } \\
\text { Blue marl }\end{array}$ & $\begin{array}{l}15 \\
35\end{array}$ & 2800 \\
\hline Blue marl............... & 105 & 190 & Dark-brown sha & 15 & 335 \\
\hline Gumbo.... & 30 & 220 & Gray sandy shale. & 24 & 359 \\
\hline
\end{tabular}


Log of L. S. Boltz well, 21 miles north of Oilton (well 136)

\begin{tabular}{|c|c|c|c|c|c|}
\hline & $\begin{array}{c}\text { Thick- } \\
\text { ness } \\
\text { (feet) }\end{array}$ & $\begin{array}{l}\text { Depth } \\
\text { (feet) }\end{array}$ & & $\begin{array}{c}\text { Thick- } \\
\text { ness } \\
\text { (feet) }\end{array}$ & $\begin{array}{l}\text { Depth } \\
\text { (feet) }\end{array}$ \\
\hline Jackson formation: & & & Jackson formation-Continued. & & \\
\hline Surface clay and gravel. & 26 & 26 & Gypsum and shale & 8 & 1,278 \\
\hline 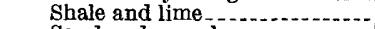 & 19 & 45 & Sandy shale and boulders; & & \\
\hline Sand and gravel & 5 & 50 & small gas show at 1,280 feet; & & \\
\hline Shale & 110 & 160 & core showed sandy shale and & & \\
\hline bo.-- & 4 & 164 & lime boulders & 4 & 1,282 \\
\hline hale... & 36 & 200 & Gummy shale. & 22 & 1,304 \\
\hline White lime............... & 10 & 210 & Shale and boulders & 3 & 1,307 \\
\hline - non & 100 & 310 & Sandy shale & 40 & 1,347 \\
\hline - n-n & 40 & 350 & Boulders and isinglass & 3 & 1,350 \\
\hline shen- & 50 & 400 & Shale & 38 & 1,388 \\
\hline e and boulders.... & 28 & 428 & Limy shale $\ldots$ & 36 & 1,424 \\
\hline e and shale........ & 72 & 500 & Gumbo & 9 & 1,433 \\
\hline (2and ar & 4 & 504 & Shale, lime, and boulders.....- & $\begin{array}{r}7 \\
34\end{array}$ & 1,440 \\
\hline Water sand ar & $\begin{array}{r}6 \\
40\end{array}$ & $\begin{array}{r}510 \\
550\end{array}$ & shale & 34 & $\begin{array}{l}1,474 \\
1,481\end{array}$ \\
\hline $\begin{array}{l}\text { Lime } \\
\text { Sandy shale. }\end{array}$ & $\begin{array}{l}40 \\
28\end{array}$ & $\begin{array}{l}500 \\
578\end{array}$ & $\begin{array}{l}\text { Gumbo } \\
\text { Sandy shale. }\end{array}$ & $\begin{array}{r}7 \\
64\end{array}$ & $\begin{array}{l}1,481 \\
1,545\end{array}$ \\
\hline Shale and bonlders. & 6 & 584 & White limerock. & $\begin{array}{r}04 \\
1\end{array}$ & $\begin{array}{l}1,040 \\
1,546\end{array}$ \\
\hline Gummy shale & 54 & 638 & Sand; run core barrel & 3 & 1,549 \\
\hline Lime. & 6 & 644 & White lime, boulders, and & & \\
\hline Limy shale. & 34 & 678 & sandy shale & 8 & 1,557 \\
\hline Gumbo & 8 & 686 & Gumbo & 12 & 1,569 \\
\hline Lime and pyrites. & 2 & 688 & Hard sandy shale and lime... & 51 & 1,620 \\
\hline Sandy shale....... & $8 \overline{5}$ & 773 & Lime boulders and shale..... & 6 & 1,626 \\
\hline Red shale & 12 & 785 & Yegua formation: & & \\
\hline and lignite... & 42 & 827 & sandy shale.............. & 44 & 1,670 \\
\hline bo & 8 & 835 & bo & 20 & 1,690 \\
\hline 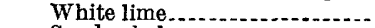 & 5 & 840 & Sulphur sand & 10 & 1,700 \\
\hline 3. & 10 & 850 & Hard black shale & 6 & 1,706 \\
\hline ale......... & 25 & 875 & Lime, boulders, and pyrites... & 6 & 1,712 \\
\hline Shale and boulders & 25 & 900 & Gumbo... & 6 & 1,718 \\
\hline Blue shale........ & 30 & 930 & Hard lime and shale.... & 22 & 1,740 \\
\hline Gumbo ... & 5 & 935 & Shale and boulders.... & 4 & 1,744 \\
\hline y shale & 45 & 980 & Brown shale & 21 & 1,765 \\
\hline $\mathrm{Li}$ & 11 & 991 & shale...... & 35 & 1,800 \\
\hline me; core at 1,002 feet. & 13 & 1,004 & bo & 7 & 1,807 \\
\hline hale. & 27 & 1,031 & 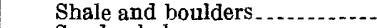 & & 1,816 \\
\hline$-\ldots$ & 21 & 1,052 & y shale $\ldots \ldots$ & 10 & 1,826 \\
\hline ders.... & 8 & 1,060 & Gumbo. & 8 & 1,834 \\
\hline ale & 21 & 1,081 & my shale. & 112 & 1,946 \\
\hline Shale and boulders & 5 & $\overrightarrow{1}, 086$ & Hard sand; shale core... & 3 & 1,949 \\
\hline Sandy shale & 4 & 1,090 & Sand .... & 2 & 1,951 \\
\hline Gumbo. & 4 & 1,094 & Sandy shale. & 42 & 1,993 \\
\hline Lignite.. & 2 & 1,096 & Limerock & 2 & 1,995 \\
\hline -..- & 26 & 1,122 & Sand; cole & 7 & 2,002 \\
\hline Shale and boulders... & 10 & 1,132 & Sandy shale & 68 & 2,070 \\
\hline $\mathrm{bo}_{\mathrm{n}}$ & 20 & 1,152 & Shale and boulders..... & 5 & 2,075 \\
\hline my shale & 25 & 1,177 & Shale and lime. & 5 & 2,080 \\
\hline Hard lime & 2 & 1,179 & Shale and boulders; gas show.- & 6 & 2,086 \\
\hline Red and gray shale with gyp- & & & Hard sandy shale......... & 44 & 2,130 \\
\hline 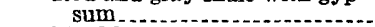 & 15 & 1,194 & Hard lime and pyrites. & 9 & 2,139 \\
\hline Hard lime & 4 & 1,198 & Lignite & 4 & 2,143 \\
\hline Hard sandy shale mixed with & & & Cook Mountain formation: & & \\
\hline lime. & 68 & 1,266 & Sand $\ldots$ & 17 & 2,160 \\
\hline Lime boulders and pyrites.... & & 1,270 & & & \\
\hline
\end{tabular}

Log of well 7 miles north of Oilton, in Carolina-Texas field below escarpment (well 140)

\begin{tabular}{|c|c|c|c|c|c|}
\hline & $\begin{array}{l}\text { Thick- } \\
\text { ness } \\
\text { (feet) }\end{array}$ & Depth & & $\begin{array}{c}\text { Thick- } \\
\text { ness } \\
\text { (feet) }\end{array}$ & $\begin{array}{l}\text { Depth } \\
\text { (feet) }\end{array}$ \\
\hline $\begin{array}{l}\text { Catahoula tufi: } \\
\text { Clay } \\
\text { Loose gravel } \\
\text { Hard sandrock }\end{array}$ & $\begin{array}{c}9.5 \\
6 \\
14.5\end{array}$ & $\begin{array}{l}9.5 \\
15.5 \\
30\end{array}$ & $\begin{array}{l}\text { Catahoula tuff-Continued. } \\
\text { Blue shale } \\
\text { Hard sandrock } \\
\text { Sand; gas and water. }\end{array}$ & $\begin{array}{r}10 \\
2 \\
23\end{array}$ & $\begin{array}{l}40 \\
42 \\
65\end{array}$ \\
\hline
\end{tabular}


Log of Rosenberg well 3.8 miles north of Oilton, in survey 270 (well 141)

\begin{tabular}{|c|c|c|c|c|c|}
\hline & $\begin{array}{l}\text { Thick- } \\
\text { ness } \\
\text { (feet) }\end{array}$ & Depth $_{\text {(feet) }}$ & & $\begin{array}{l}\text { Thick- } \\
\text { ness } \\
\text { (feet) }\end{array}$ & $\begin{array}{l}\text { Depth } \\
\text { (feet) }\end{array}$ \\
\hline $\begin{array}{l}\text { Catahoula tuff: } \\
\text { Soil }\end{array}$ & & & Catahoula tuff-Continued. & & \\
\hline Packed sand......... & $\begin{array}{l}2 \\
8\end{array}$ & 10 & Sticky shale & $\begin{array}{l}85 \\
10\end{array}$ & 320 \\
\hline Red shale......... & 3 & 13 & Hard shale and lime. & 1 & 321 \\
\hline Packed sand. & 8 & 21 & Hard shale......... & 9 & 330 \\
\hline Red shale ..... & 8 & 29 & Sticky shale... & 3 & 333 \\
\hline Gravel and clay.. & 3 & 32 & Hard rock ...... & 24 & 357 \\
\hline Shale......... & 21 & 53 & Sand ..... & 14 & 371 \\
\hline Clay and small gravel. & 2 & 55 & Shale..... & 7 & 378 \\
\hline Shale & 8 & 63 & Hard sandy shale....... & 12 & 390 \\
\hline Hard shale and pebbles... & 17 & 80 & Shale... & 12 & 402 \\
\hline Shale................... & 6 & 86 & Sticky shale. & 12 & 414 \\
\hline Hard sandy shale.-. & 4 & 90 & Shale & 10 & 424 \\
\hline Sand; salt water & 14 & 104 & Shale and boulders. & 4 & 428 \\
\hline Hard sandy shale... & 12 & 116 & Sticky shale & 6 & 434 \\
\hline Shale_..... & 16 & 132 & Shale & 41 & 475 \\
\hline Sandrock.. & 1 & 133 & Shale and shells... & 2 & 477 \\
\hline Hard shale. & 16 & 149 & Sticky shale _... & 5 & 482 \\
\hline Sand............ & 16 & 165 & Hard shale......... & 31 & 513 \\
\hline Sandy shale. & 50 & 215 & Limerock & 5 & 518 \\
\hline Shale......... & 12 & 227 & & & \\
\hline
\end{tabular}

Log of Rosenberg water well 21/2 miles northeast of Oilton, in survey 339 (well 142)

\begin{tabular}{|c|c|c|c|c|c|}
\hline & $\begin{array}{l}\text { Thick- } \\
\text { ness } \\
\text { (feet) }\end{array}$ & $\begin{array}{l}\text { Depth } \\
\text { (feet) }\end{array}$ & & $\begin{array}{l}\text { Thick- } \\
\text { ness } \\
\text { (feet) }\end{array}$ & $\begin{array}{l}\text { Depth } \\
\text { (feet) }\end{array}$ \\
\hline $\begin{array}{l}\text { Goliad sand: } \\
\text { Soil } \\
\text { Limestone } \\
\text { Packed sand. } \\
\text { Gravel and water } \\
\text { Gravel and }\end{array}$ & $\begin{array}{r}1 \\
4 \\
35 \\
10 \\
4\end{array}$ & $\begin{array}{r}1 \\
5 \\
40 \\
50 \\
54\end{array}$ & $\begin{array}{l}\text { Catahoula tuff: } \\
\text { Light-yellow rock } \\
\text { White sticky shale }\end{array}$ & $\begin{array}{l}7 \\
4\end{array}$ & $\begin{array}{l}61 \\
65\end{array}$ \\
\hline
\end{tabular}

Log of Rosenberg water well $2 \frac{1}{2}$ miles northeast of Oilton, in survey 333 (well 143)

\begin{tabular}{|c|c|c|c|c|c|}
\hline & $\begin{array}{l}\text { Thick- } \\
\text { ness } \\
\text { (feet) }\end{array}$ & $\begin{array}{l}\text { Depth } \\
\text { (feet) }\end{array}$ & & $\begin{array}{c}\text { Thick- } \\
\text { ness } \\
\text { (feet) }\end{array}$ & $\begin{array}{l}\text { Depth } \\
\text { (feet) }\end{array}$ \\
\hline 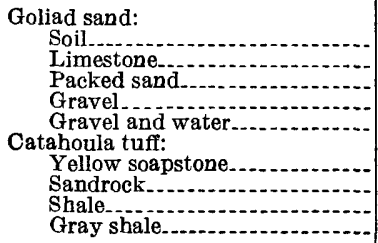 & $\begin{array}{r}3 \\
3 \\
31 \\
9 \\
16 \\
18 \\
7 \\
13 \\
15\end{array}$ & $\begin{array}{r}3 \\
6 \\
37 \\
46 \\
62 \\
\\
80 \\
87 \\
100 \\
115\end{array}$ & $\begin{array}{l}\text { Catahoula tuff-Continued: } \\
\text { Blue shale-_oft shale } \\
\text { Hard and soft } \\
\text { Sticky shale. } \\
\text { Red beds } \\
\text { Hard sandy shale } \\
\text { Sand and shale } \\
\text { Sticky shale. } \\
\text { Shale } \\
\text { Sand; no water } \\
\text { Blue shale.... }\end{array}$ & $\begin{array}{r}35 \\
80 \\
10 \\
18 \\
15 \\
27 \\
15 \\
15 \\
5 \\
15\end{array}$ & $\begin{array}{l}150 \\
230 \\
240 \\
258 \\
273 \\
300 \\
315 \\
330 \\
335 \\
350\end{array}$ \\
\hline
\end{tabular}


Log of A. G. Long well 2.8 miles southeast of Oilton, in survey 1009 (well 169)

\begin{tabular}{|c|c|c|c|c|c|}
\hline & $\begin{array}{c}\text { Thiek- } \\
\text { ness } \\
\text { (feet) }\end{array}$ & $\begin{array}{l}\text { Depth } \\
\text { (feet) }\end{array}$ & & $\begin{array}{c}\text { Thiok- } \\
\text { ness } \\
\text { (feet) }\end{array}$ & $\begin{array}{l}\text { Depth } \\
\text { (feet) }\end{array}$ \\
\hline Goliad sand: & & & Catahoula tuff-Continued: & & \\
\hline $\begin{array}{l}\text { Dark sandy soil } \\
\text { Limestone.............. }\end{array}$ & $\begin{array}{l}6 \\
6\end{array}$ & $\begin{array}{r}6 \\
12\end{array}$ & $\begin{array}{l}\text { Red shale } \\
\text { Blue sandrock }\end{array}$ & $\begin{array}{r}9 \\
12\end{array}$ & $\begin{array}{l}280 \\
292\end{array}$ \\
\hline Packed sand.............. & 24 & 36 & Sand & 1 & 293 \\
\hline Sandrock & 9 & 45 & Blue sandrock & 2 & 295 \\
\hline Sand, gravel, and water. & 10 & 55 & Hard sandrock. & 5 & 300 \\
\hline Catahoula tuff: & & & Sand ............. & 2 & 302 \\
\hline Yellow sticky shale. & 45 & 100 & Sandrock & 3 & 305 \\
\hline Broken sandstone.. & 5 & 105 & Red and blue shale & 51 & 356 \\
\hline Light-yellow coarse water sand. & 10 & 115 & Sandrock & 5 & 361 \\
\hline Broken sandrock & 26 & 141 & Blue shale. & 9 & 370 \\
\hline Dark sandrock.. & 2 & 143 & Limerock and pyrites... & 1 & 371 \\
\hline Light-blue shale.. & 27 & 170 & Hard sticky blue shale... & 7 & 378 \\
\hline Gray shale.. & 7 & 177 & Light-blue sandy shale. & 46 & 424 \\
\hline Hard sandy gray shale.... & 5 & 182 & Hard sandrock & 4 & 428 \\
\hline Blue shale & 18 & 200 & Sandy shale . ......... & 5 & 433 \\
\hline Red and blue shale... & 70 & 270 & Hard blue sandrock & 7 & 440 \\
\hline Sandrock & 1 & 271 & Blue shale.................. & 68 & 508 \\
\hline
\end{tabular}

Log of Houston Oil Co.'s well 1.3 miles northwest of Bruni, at Hoco Club (well 17O)

\begin{tabular}{|c|c|c|c|c|c|}
\hline & $\begin{array}{c}\text { Thick- } \\
\text { ness } \\
\text { (feet) }\end{array}$ & $\begin{array}{c}\text { Depth } \\
\text { (feet) }\end{array}$ & & $\begin{array}{c}\text { Thick- } \\
\text { ness } \\
\text { (feet) }\end{array}$ & $\begin{array}{l}\text { Depth } \\
\text { (feet) }\end{array}$ \\
\hline $\begin{array}{l}\text { Goliad sand: } \\
\text { Sand } \\
\text { Limerock } \\
\text { Clay } \\
\text { Hard sandrock } \\
\text { Sand } . . . . .\end{array}$ & $\begin{array}{r}3 \\
38 \\
6 \\
7 \\
21\end{array}$ & $\begin{array}{r}3 \\
41 \\
47 \\
54 \\
75\end{array}$ & $\begin{array}{l}\text { Catahoula tuff: } \\
\text { Pink shale } \\
\text { Gumbo and shale } \\
\text { Hard sandy shale } \\
\text { Coarse water sand........... }\end{array}$ & $\begin{array}{r}100 \\
45 \\
13 \\
37\end{array}$ & $\begin{array}{l}175 \\
220 \\
233 \\
270\end{array}$ \\
\hline
\end{tabular}

Log of Houston Oil Co.'s well 1 mile northwest of Bruni, at Hoco tank farm (well 171)

\begin{tabular}{|c|c|c|c|c|c|}
\hline & $\begin{array}{c}\text { Thick- } \\
\text { ness } \\
\text { (feet) }\end{array}$ & $\begin{array}{l}\text { Depth } \\
\text { (feet) }\end{array}$ & & $\begin{array}{c}\text { Thick- } \\
\text { ness } \\
\text { (feet) }\end{array}$ & $\begin{array}{l}\text { Depth } \\
\text { (feet) }\end{array}$ \\
\hline $\begin{array}{l}\text { Goliad sand: } \\
\text { Red soil- } \\
\text { Caliche } \\
\text { Sand and gravel } \\
\text { Hard sandrock } \\
\text { Catahoula tuff: } \\
\quad \text { Red gumbo }\end{array}$ & $\begin{array}{r}3 \\
15 \\
9 \\
23 \\
65\end{array}$ & $\begin{array}{r}3 \\
18 \\
27 \\
50 \\
115\end{array}$ & $\begin{array}{l}\text { Catahoula tuff-Continued. } \\
\text { Red shale } \\
\text { Pink shale } \\
\text { Coarse water sand (brackish) } \\
\text { Red gumbo-.... } \\
\text { Water sand- } \\
\text { Blue shale.... }\end{array}$ & \begin{tabular}{r|}
60 \\
55 \\
25 \\
7 \\
3 \\
12
\end{tabular} & $\begin{array}{l}175 \\
230 \\
255 \\
262 \\
265 \\
277\end{array}$ \\
\hline
\end{tabular}

Log of Crown Central Petroleum Co.'s water well, \& miles south of Mirando City (well 178)

\begin{tabular}{|c|c|c|c|c|c|}
\hline & $\begin{array}{c}\text { Thick- } \\
\text { ness } \\
\text { (feet) }\end{array}$ & $\underset{\text { (feet) }}{\text { Depth }}$ & & $\begin{array}{c}\text { Thick- } \\
\text { ness } \\
\text { (feet) }\end{array}$ & $\begin{array}{l}\text { Depth } \\
\text { (feet) }\end{array}$ \\
\hline $\begin{array}{l}\text { Catahoula tuff: } \\
\text { Surface soil } \\
\text { Clay } \\
\text { Clay and sand }\end{array}$ & $\begin{array}{r}10 \\
8 \\
27\end{array}$ & $\begin{array}{l}10 \\
18 \\
45\end{array}$ & 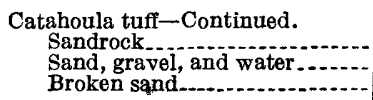 & $\begin{array}{r}8 \\
47 \\
12\end{array}$ & $\begin{array}{r}53 \\
100 \\
112\end{array}$ \\
\hline
\end{tabular}


Log of Magnolia Petroleum Co.'s water well in Albercas field (well 188)

\begin{tabular}{|c|c|c|c|c|c|}
\hline & $\begin{array}{c}\text { Thick- } \\
\text { ness } \\
\text { (feet) }\end{array}$ & $\begin{array}{c}\text { Depth } \\
\text { (feet) }\end{array}$ & & $\begin{array}{c}\text { Thick- } \\
\text { ness } \\
\text { (feet) }\end{array}$ & $\begin{array}{l}\text { Depth } \\
\text { (feet) }\end{array}$ \\
\hline $\begin{array}{l}\text { Goliad sand: } \\
\text { Clay and gravel } \\
\text { Hard pack sand. } \\
\text { Shale.. } \\
\text { Sand and gravel } \\
\text { Catahoula tuff: } \\
\text { Shale... }\end{array}$ & $\begin{array}{r}33 \\
24 \\
26 \\
20 \\
\\
153\end{array}$ & $\begin{array}{r}33 \\
57 \\
83 \\
103 \\
\\
256\end{array}$ & $\begin{array}{l}\text { Catahoula tuff-Continued. } \\
\text { Broken sand } \\
\text { Broken shale } \\
\text { Sand. } \\
\text { Shale } \\
\text { Water sand }\end{array}$ & $\begin{array}{l}23 \\
61 \\
17 \\
23 \\
25\end{array}$ & $\begin{array}{l}279 \\
340 \\
357 \\
380 \\
405\end{array}$ \\
\hline
\end{tabular}

Log of Carolina Texas Oil Co.'s Barnsley No. 2 well, on survey 268, about 7 miles north-northeast of Oilton

\begin{tabular}{|c|c|c|c|c|c|}
\hline & $\begin{array}{c}\text { Thick- } \\
\text { ness } \\
\text { (feet) }\end{array}$ & $\begin{array}{l}\text { Depth } \\
\text { (feet) }\end{array}$ & & $\begin{array}{c}\text { Thick- } \\
\text { ness } \\
\text { (feet) }\end{array}$ & $\begin{array}{l}\text { Depth } \\
\text { (feet) }\end{array}$ \\
\hline Catahoula tuff: & & & Catahoula tuff-Continued. & & \\
\hline Sand & 25 & 25 & Hard sand. & 31 & 626 \\
\hline Rock & 2 & 27 & Gumbo & 9 & 635 \\
\hline Packed sand. & 33 & 60 & Hard sand. & 20 & 655 \\
\hline Hard sand & 25 & 85 & Pink gumbo. & 69 & 724 \\
\hline Rock & 3 & 88 & Gumbo & 21 & 745 \\
\hline Hard sand & 27 & 115 & Sticky shale. & 45 & 790 \\
\hline Sand $\ldots$ & 20 & 135 & Hard sand.......... & 20 & 810 \\
\hline Packed sand. & 10 & 145 & Rock & 3 & 813 \\
\hline Pink gumbo & 20 & 165 & Hard sand & 12 & 825 \\
\hline Sand and boulders & 25 & 190 & Sticky shale....... & 35 & 860 \\
\hline Gumbo & 5 & 195 & Gumbo & 28 & 888 \\
\hline 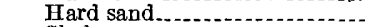 & 20 & 215 & 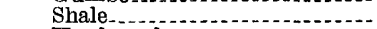 & 27 & 915 \\
\hline Shale & 25 & 240 & Hard sand & 20 & 935 \\
\hline Gumbo & 20 & 260 & Frio clay: & & \\
\hline Sand, shale, and boulders..... & 55 & 315 & Gumbo... & 25 & 960 \\
\hline Hard sand & 29 & 344 & Shale & 30 & 990 \\
\hline Sand and boulders & 31 & 375 & Gumbo.- & 30 & 1,020 \\
\hline Rock & 6 & 381 & Sandy shale....... & 40 & 1,060 \\
\hline Sand and shale. & 24 & 405 & Hard sand & 30 & 1,090 \\
\hline Gumbo & 39 & 444 & Pink gumbo....... & 102 & 1,192 \\
\hline Rock & 2 & 446 & Gumbo & 28 & 1,220 \\
\hline Sand, shale, and boulders..... & 44 & 490 & Shale & 60 & 1,280 \\
\hline Gumbo. & 7 & 497 & Jackson formation: & & \\
\hline Shale & 18 & 515 & Shale and shells & 12 & 1,292 \\
\hline Pink gumbo_....................... & 55 & 570 & Rock & & 1,296 \\
\hline Shale & 25 & & Gas and water sand... & 9 & 305 \\
\hline
\end{tabular}





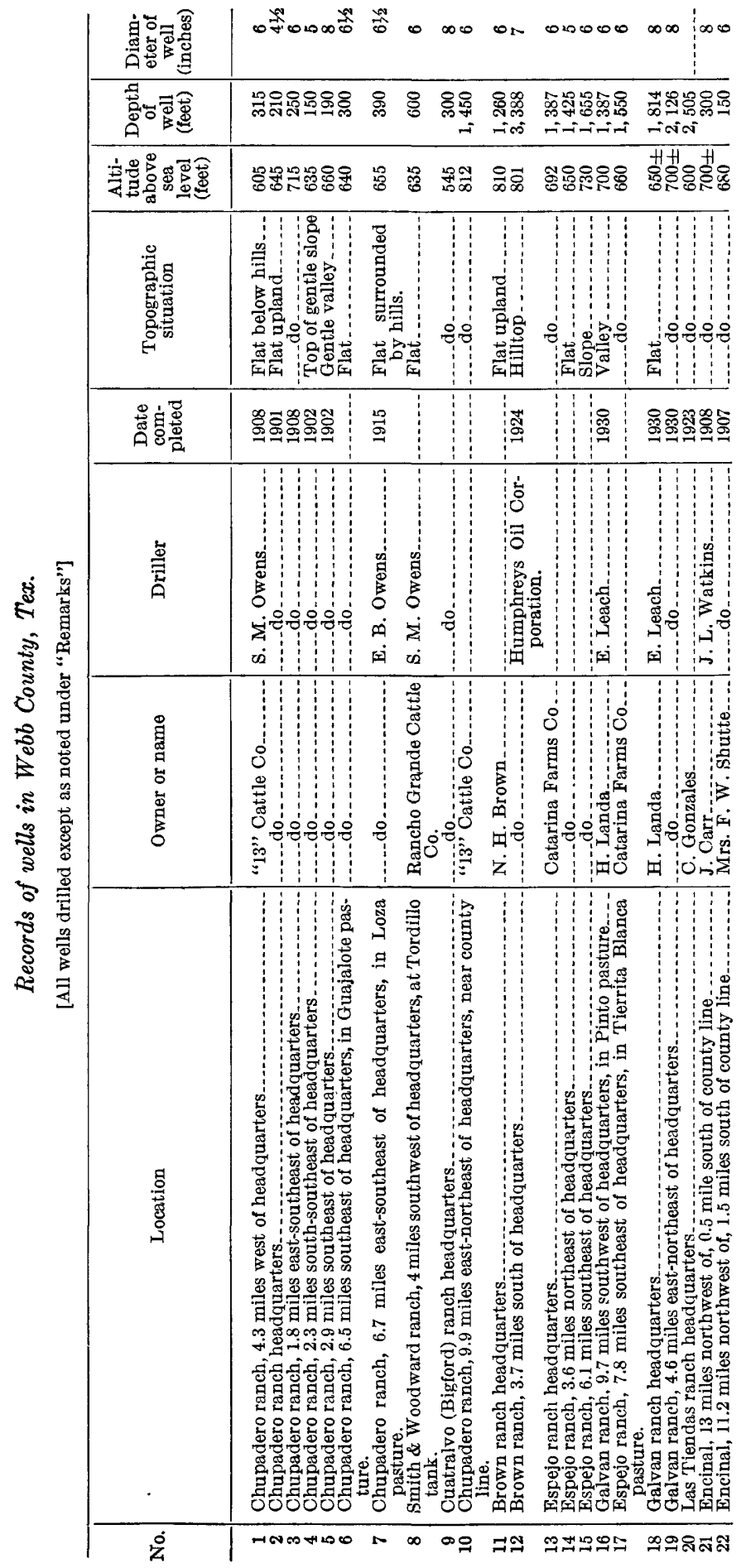




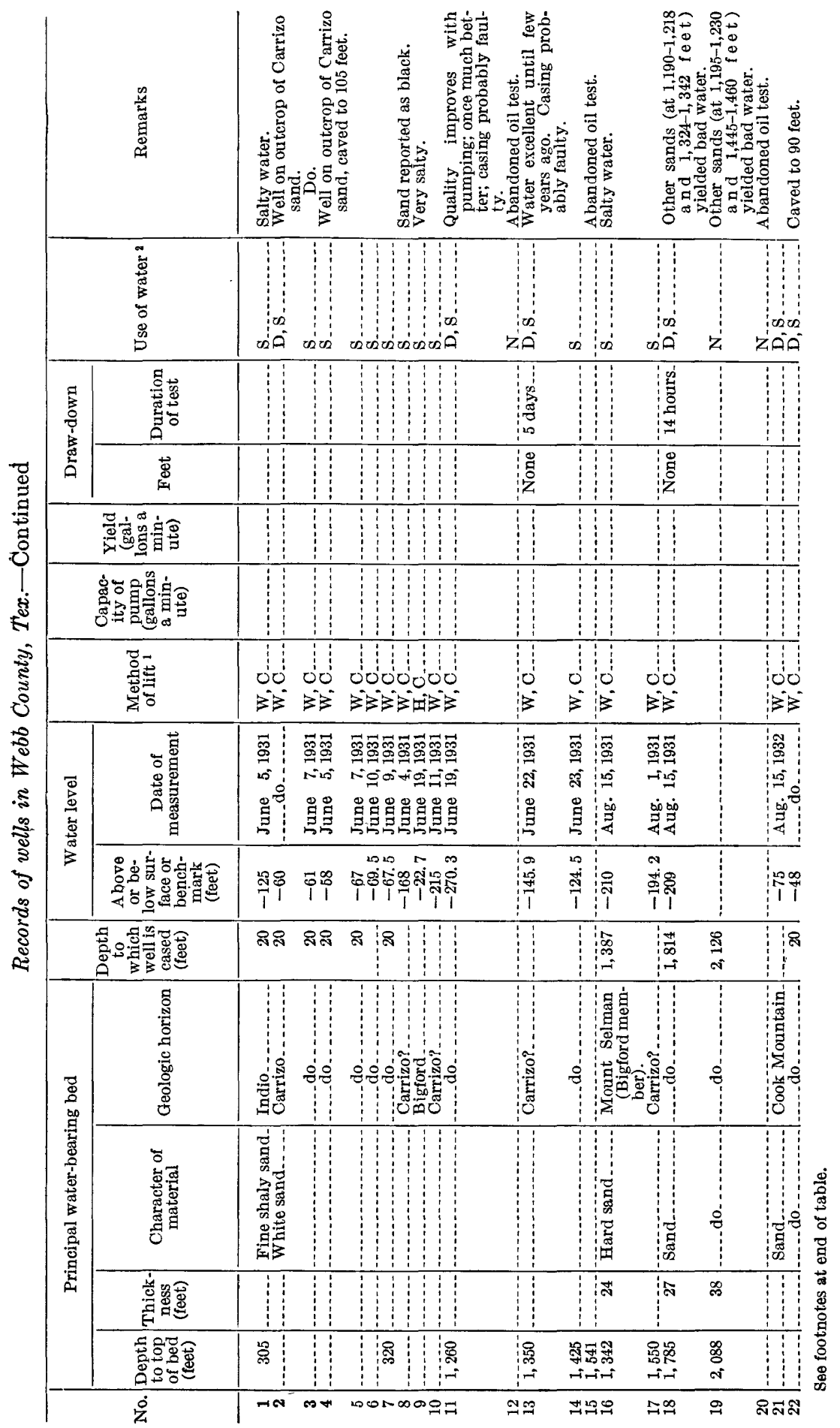




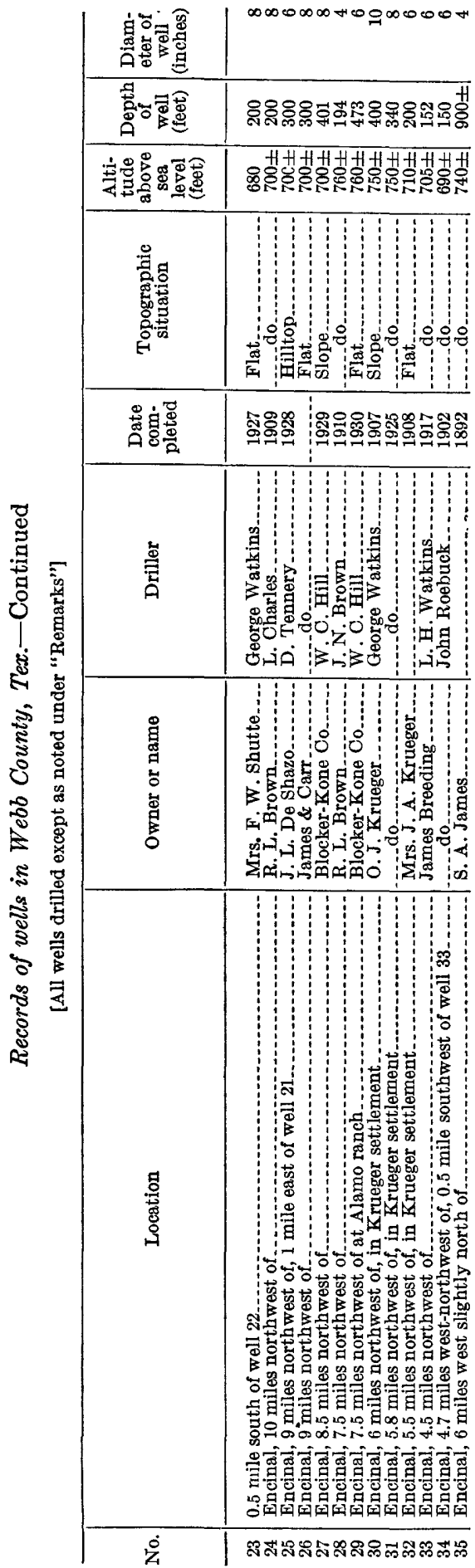


WELL TABLES

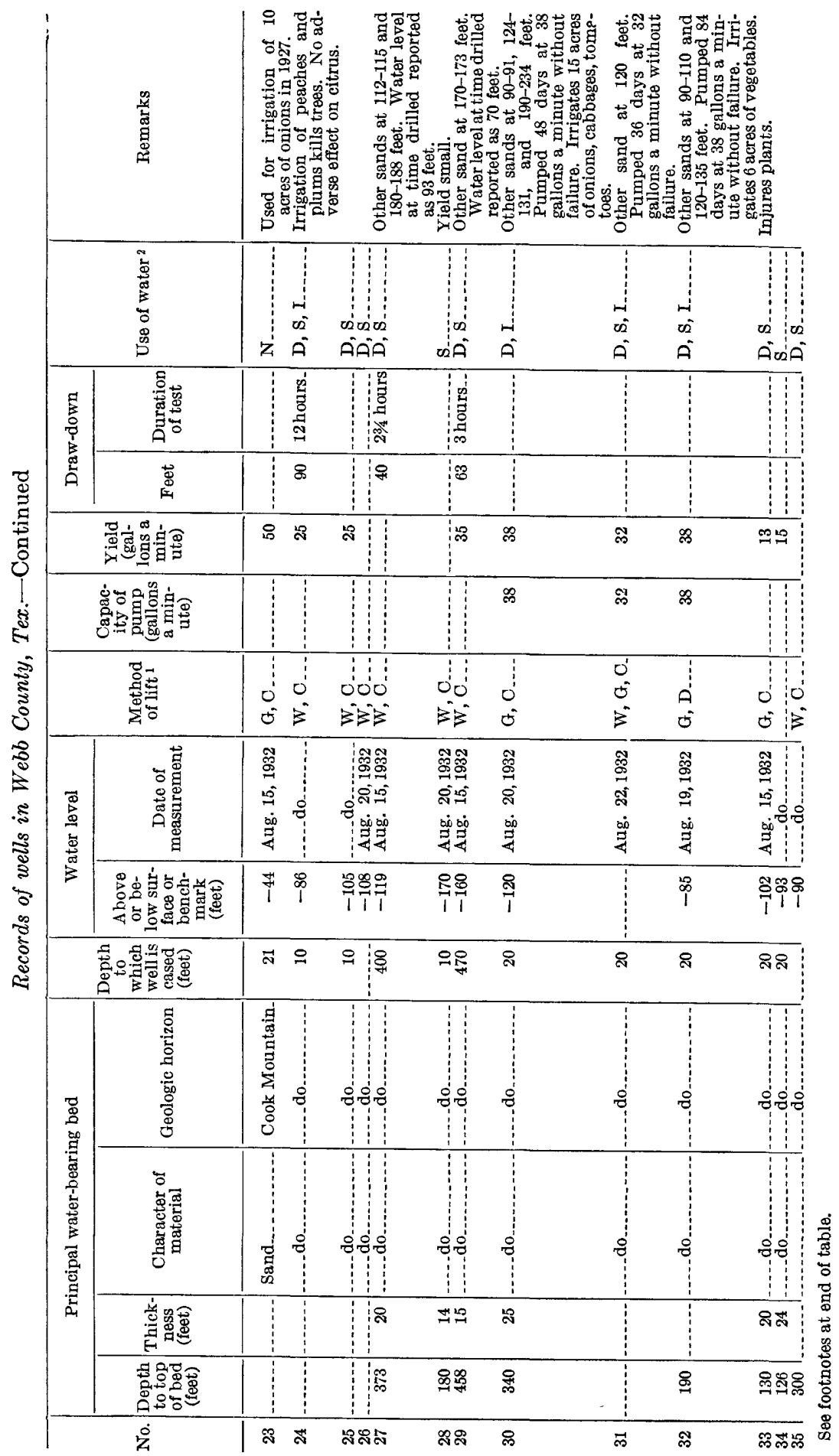




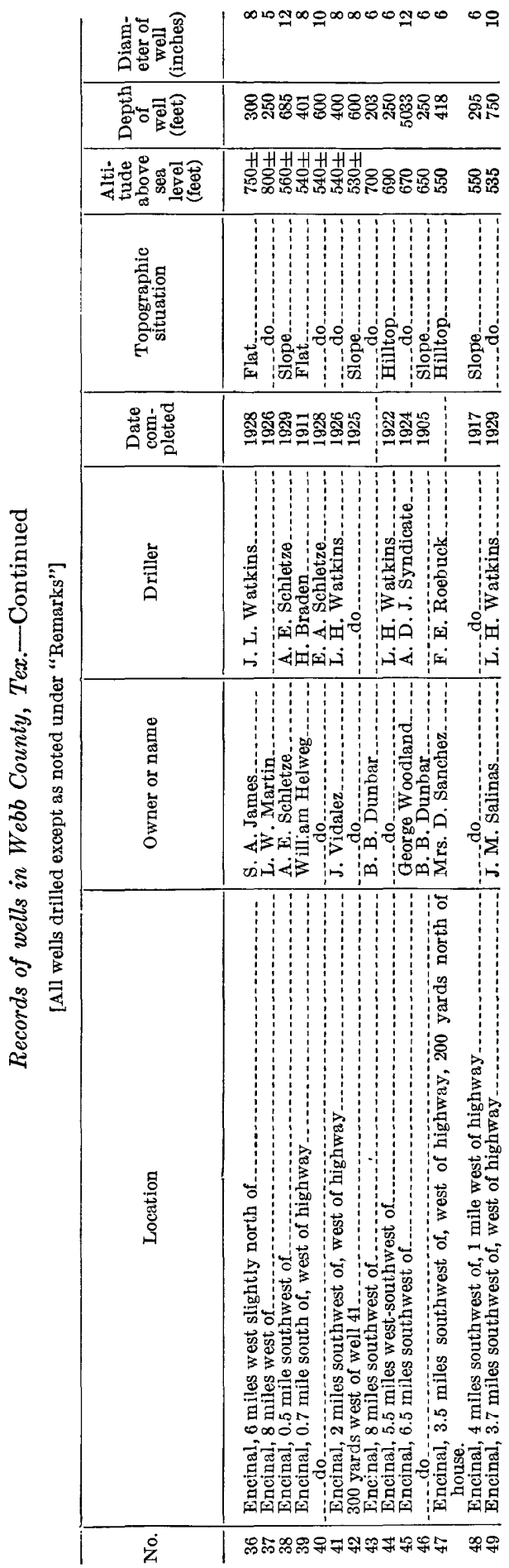


WELL TABLES

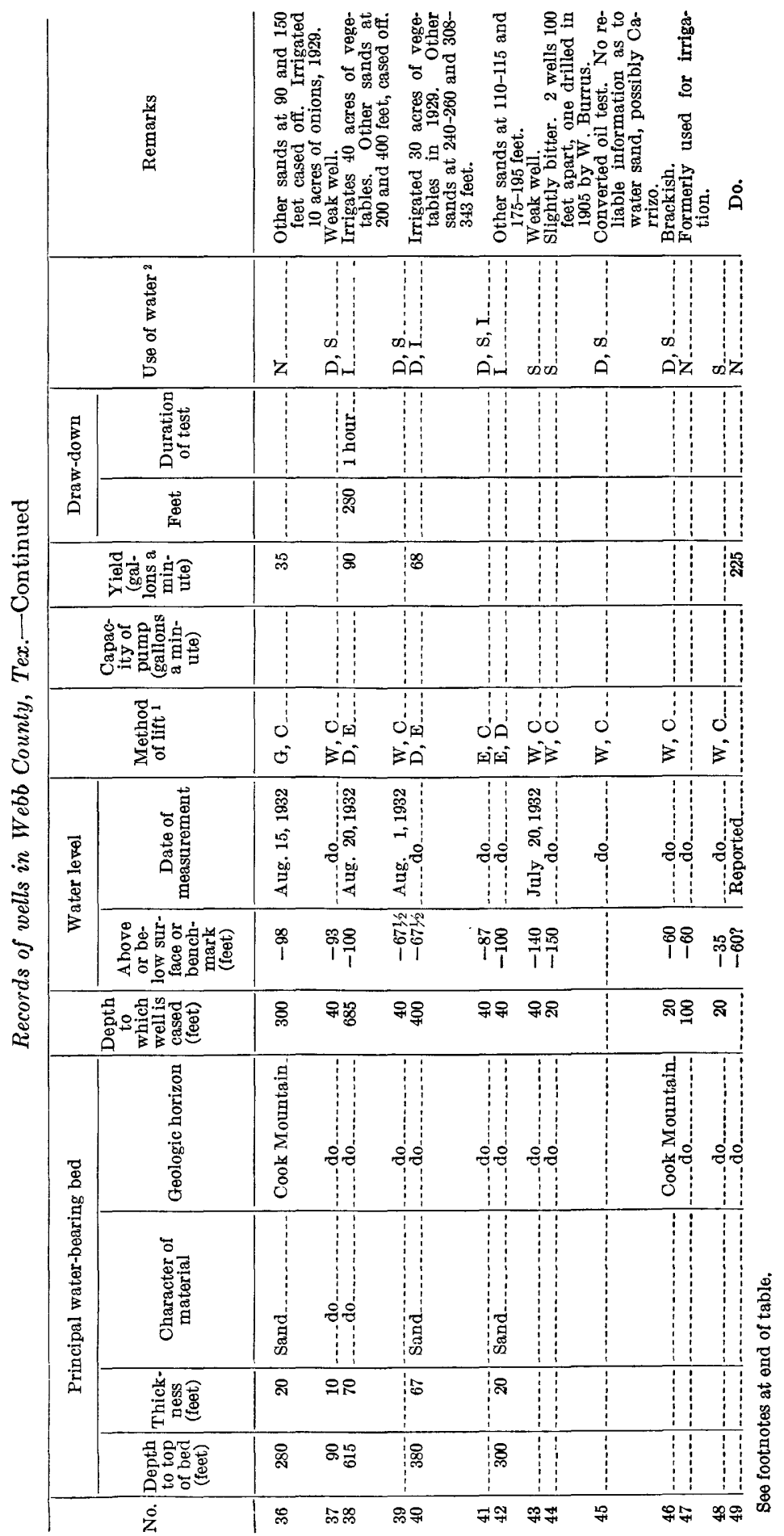




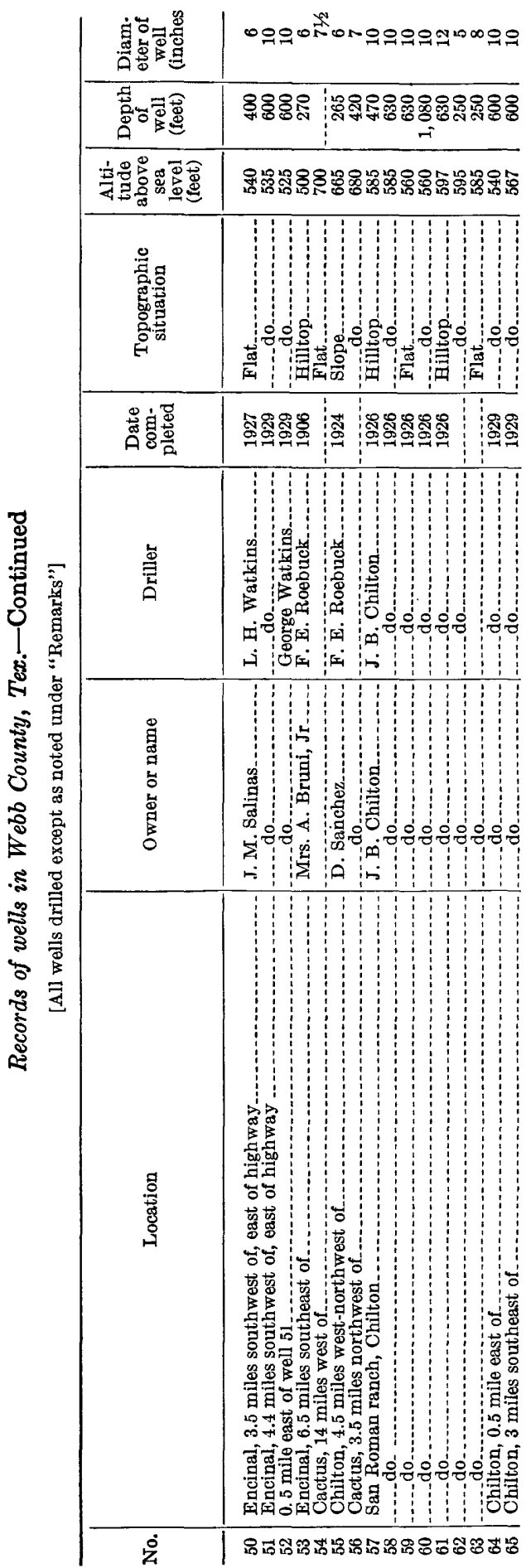


WELL TABLES

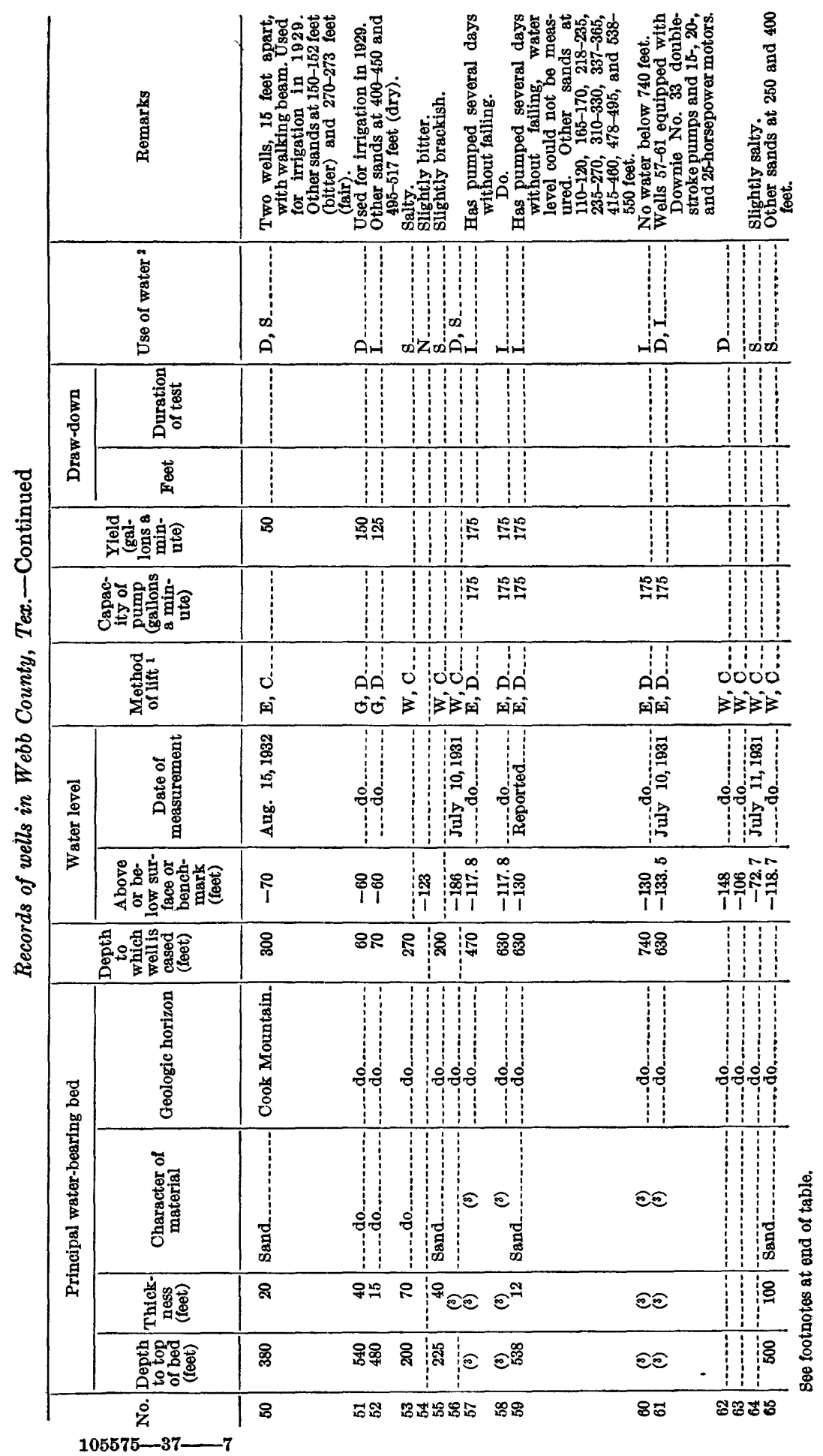




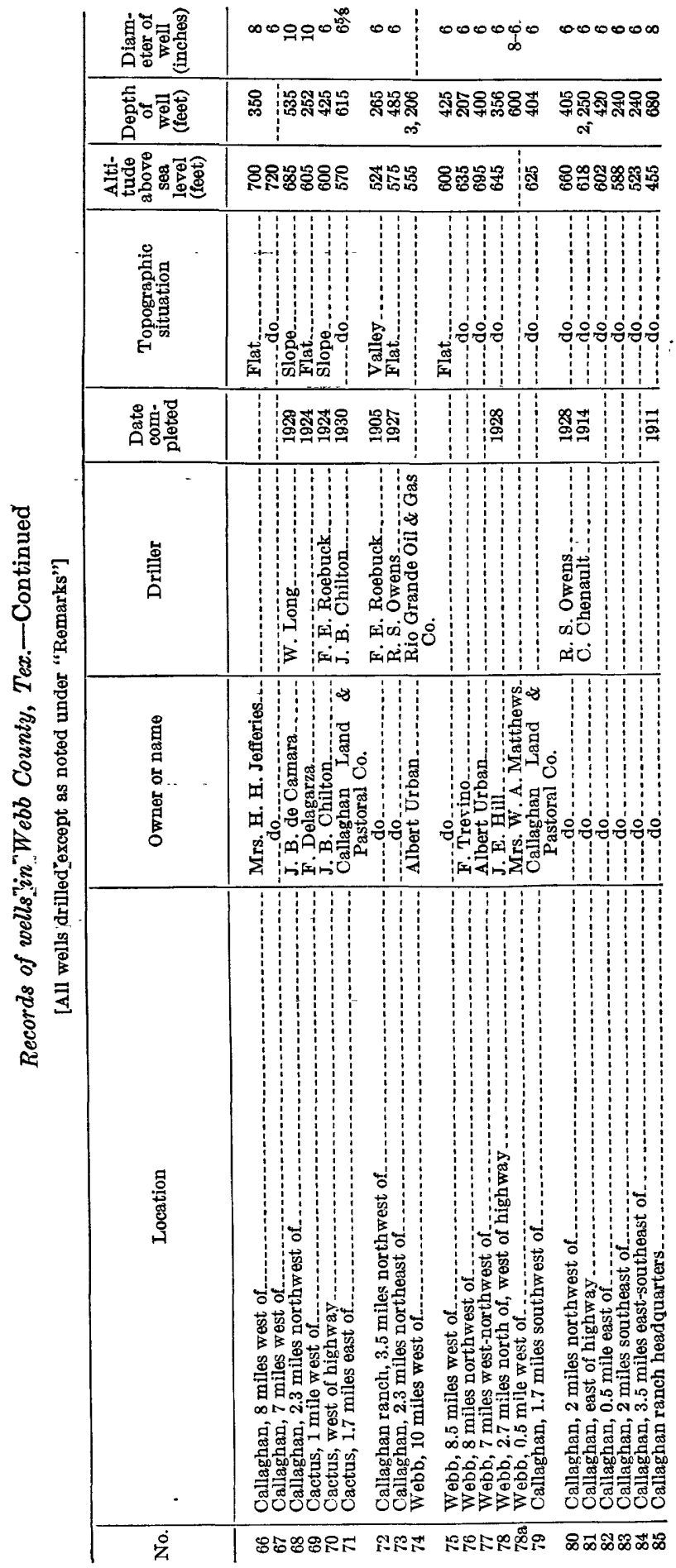


WELL TABLES

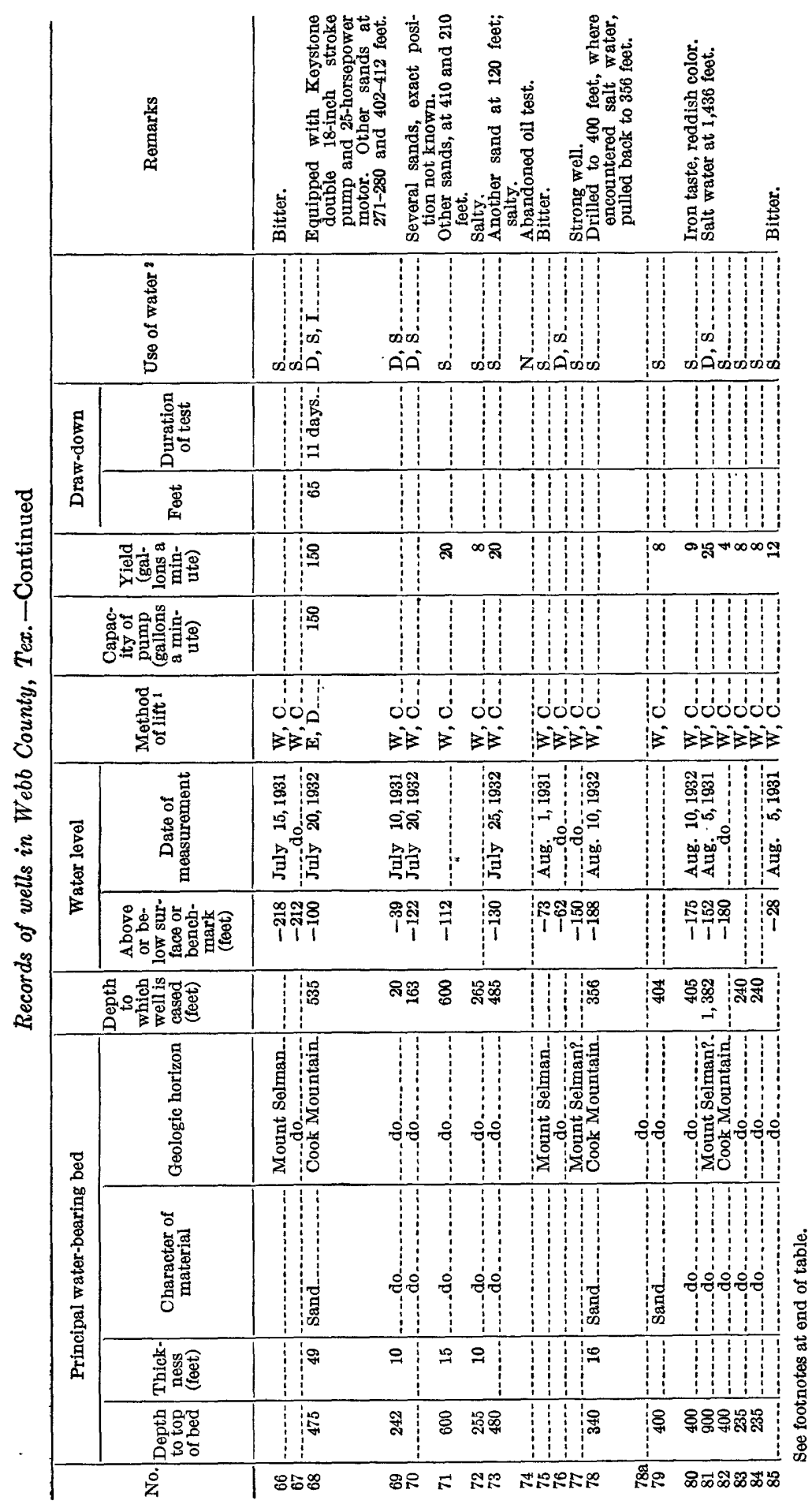




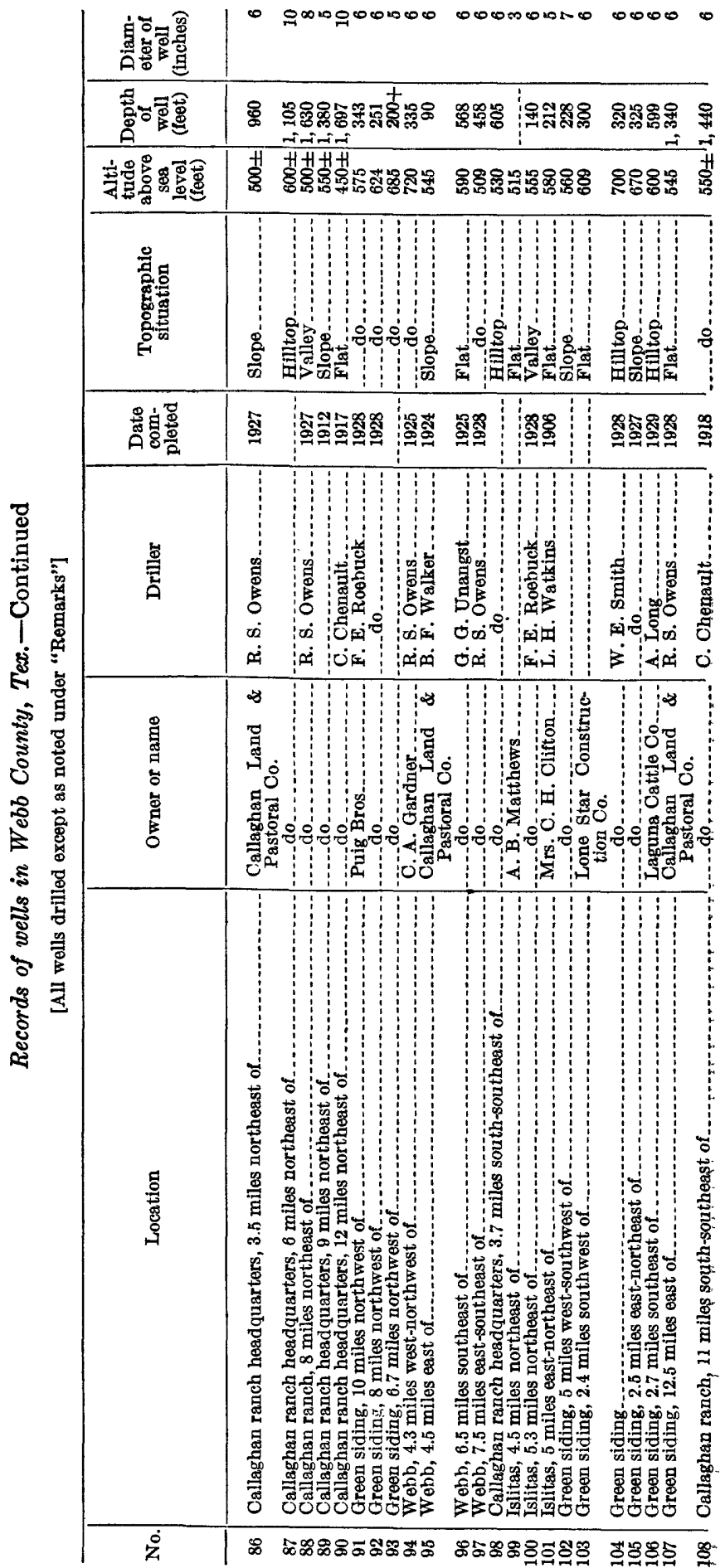


WELL TABLES

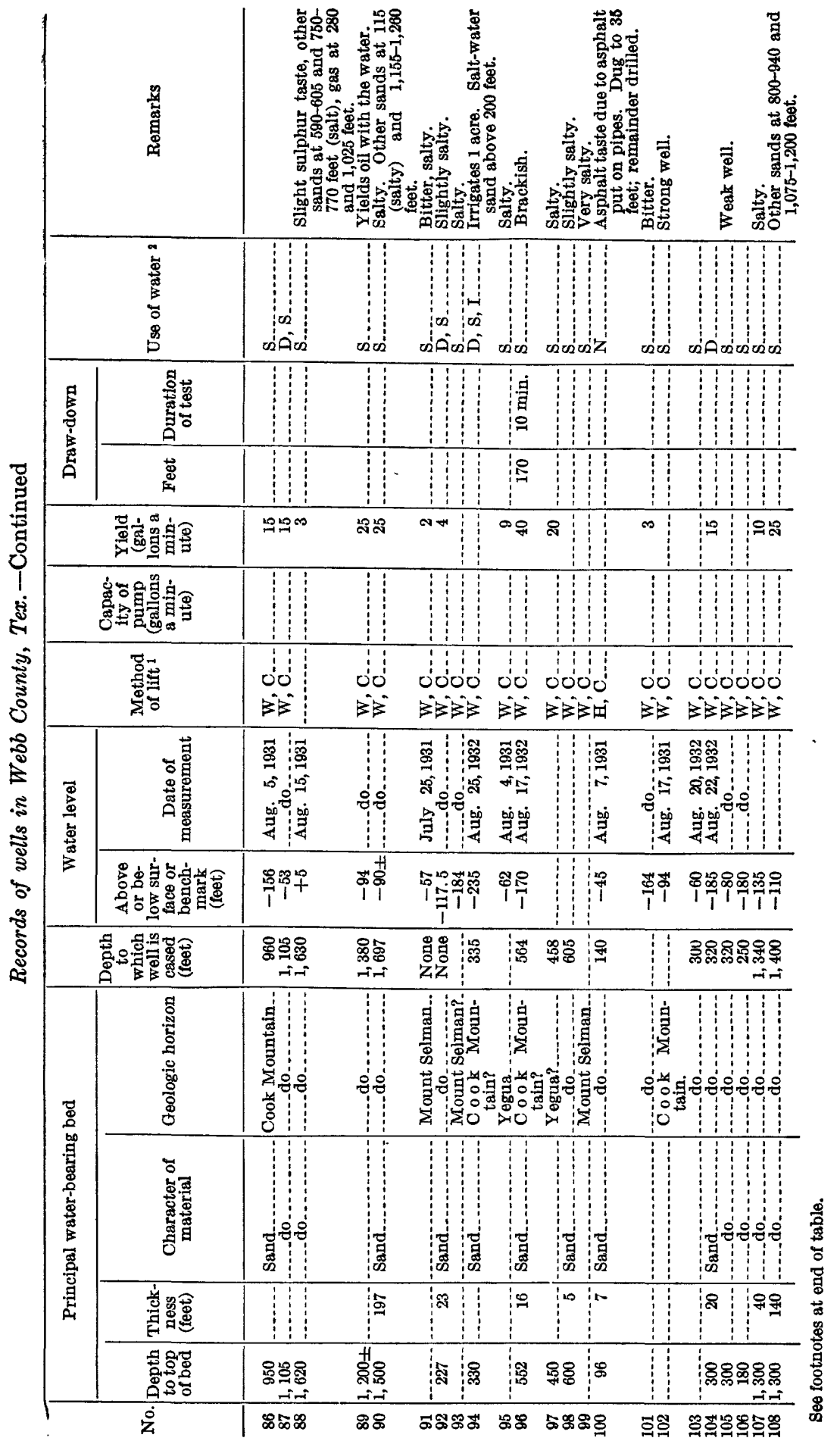




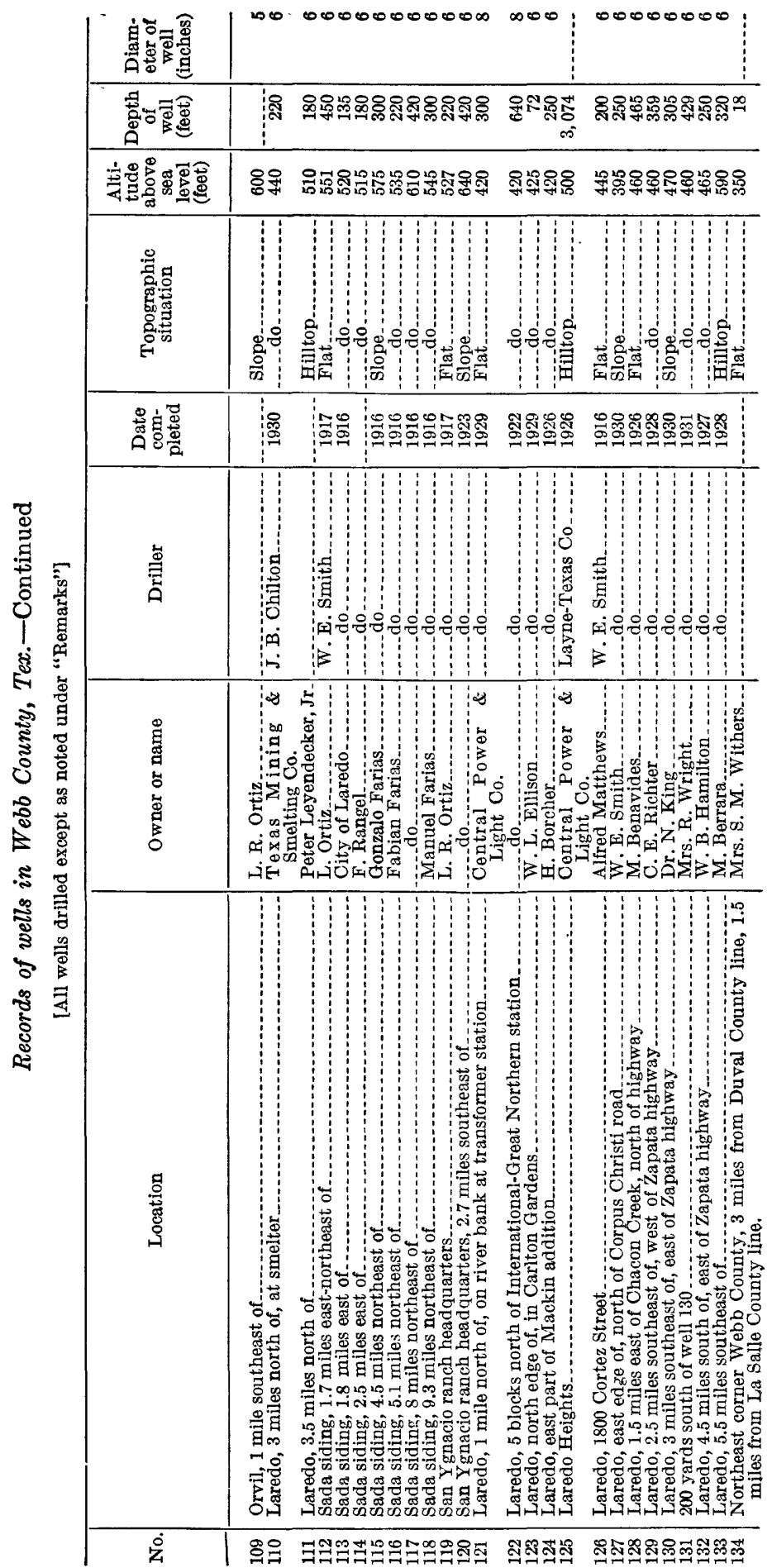


WELL TABLES

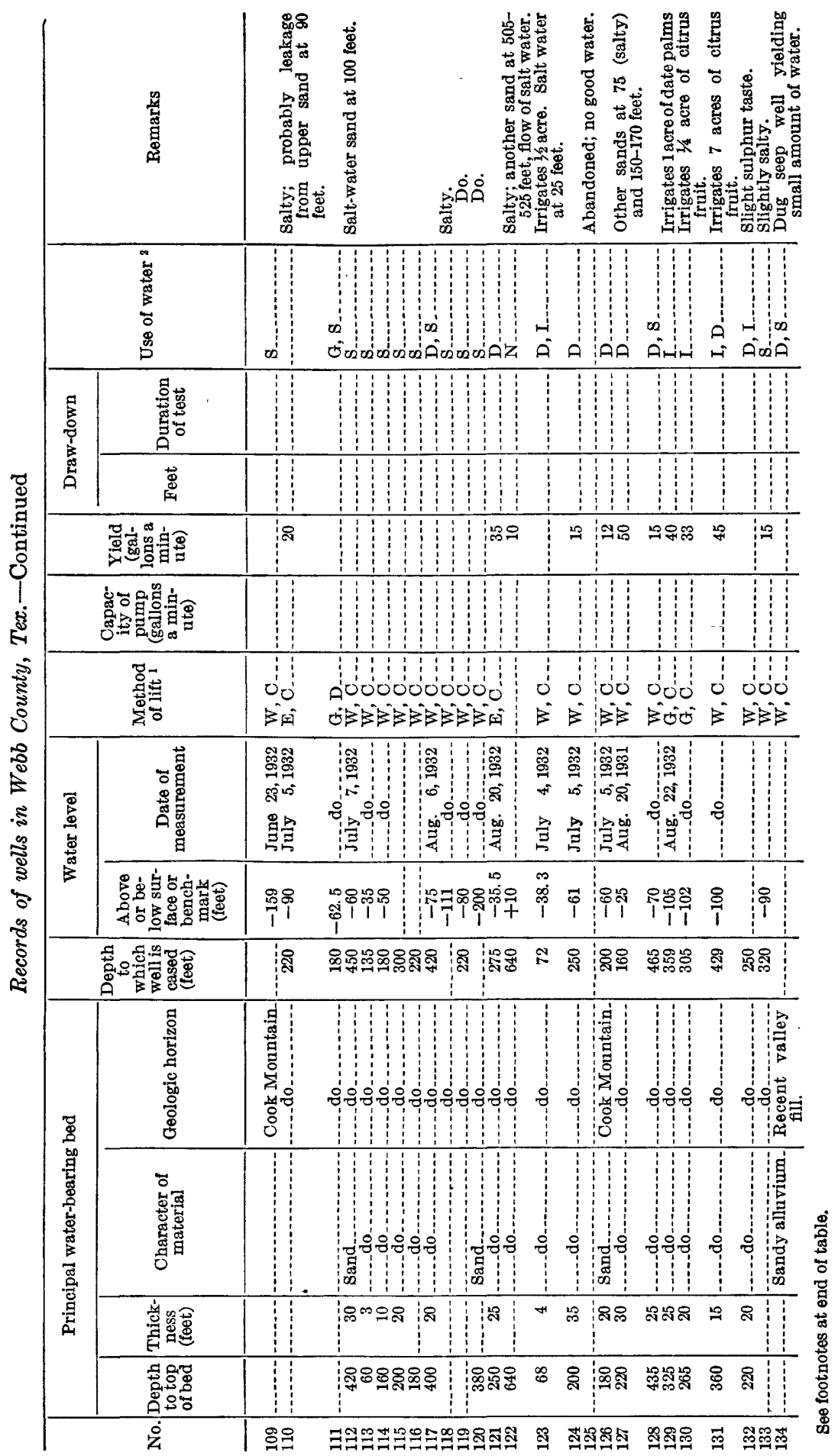




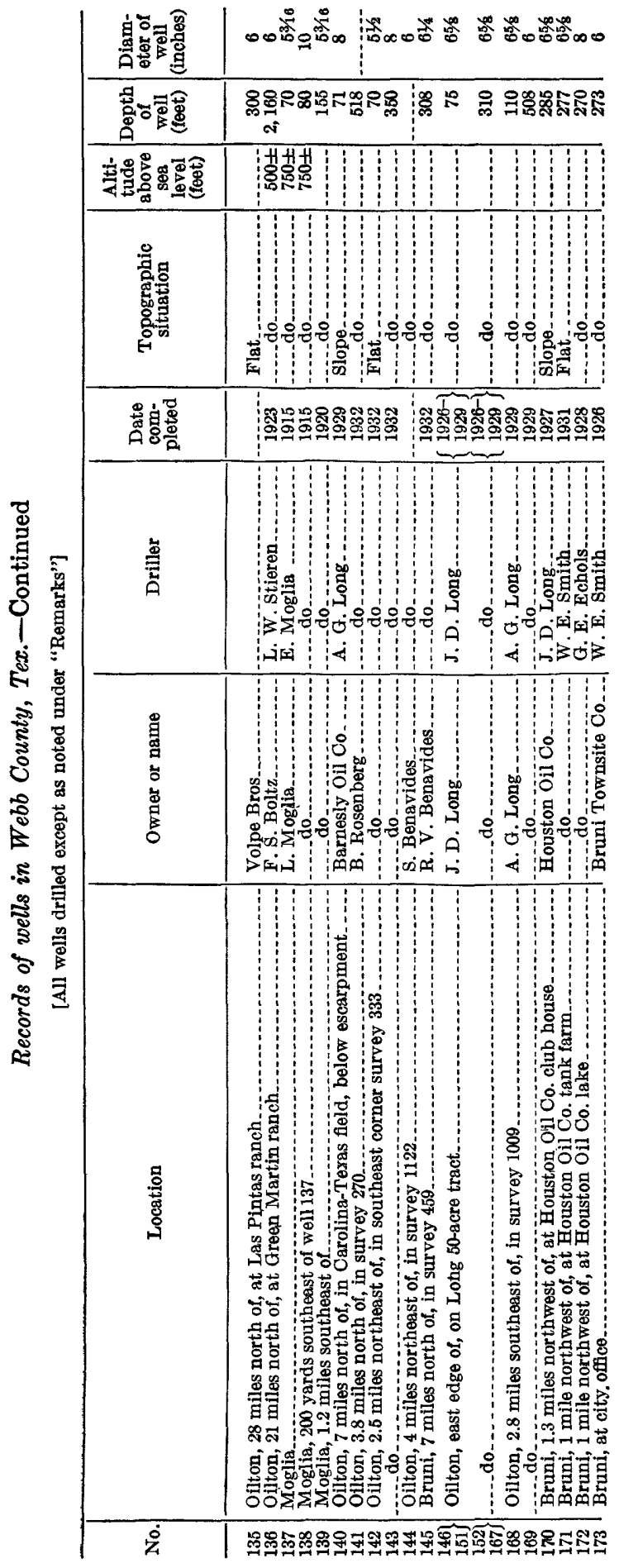


WELL TABLES

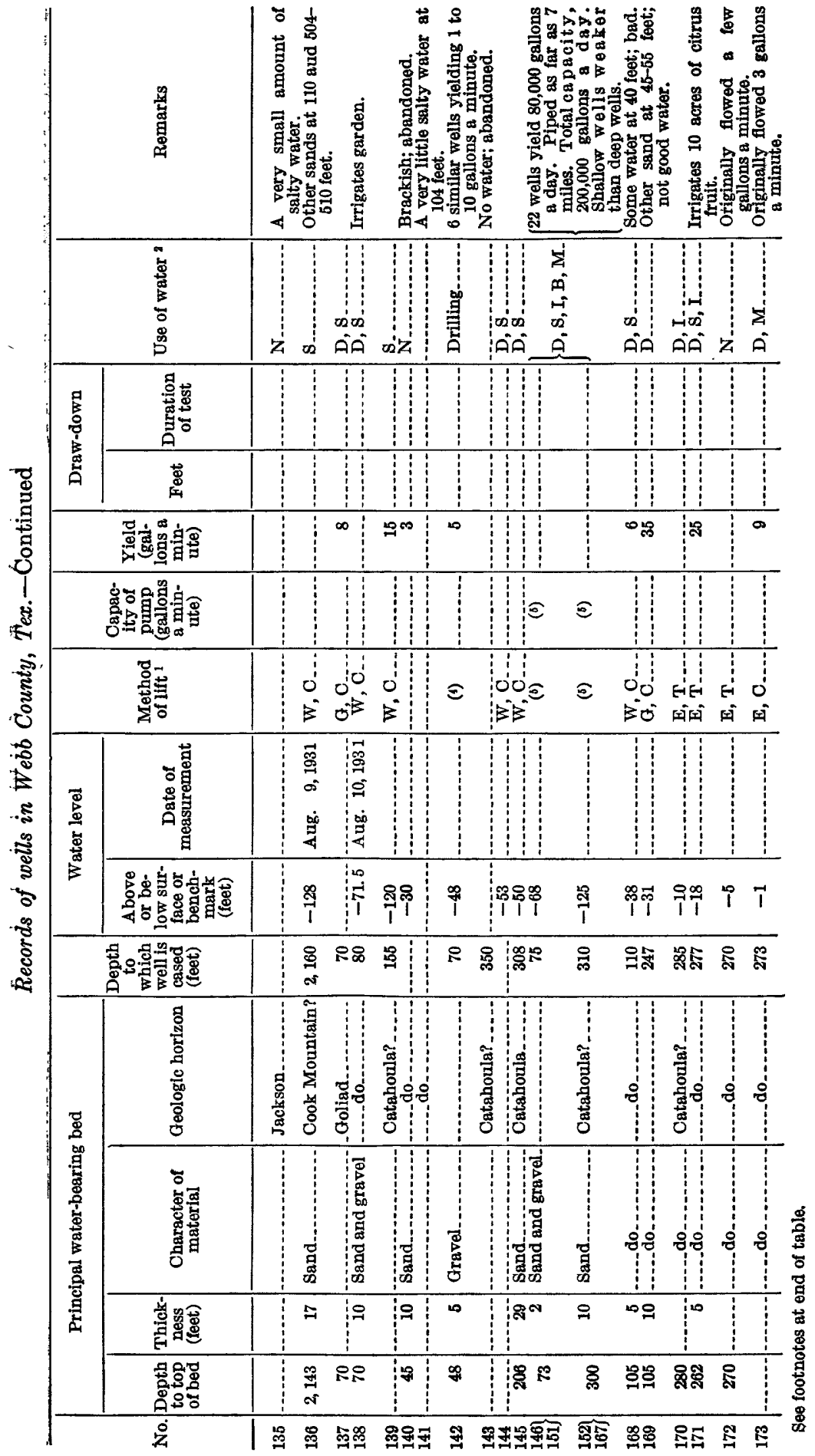




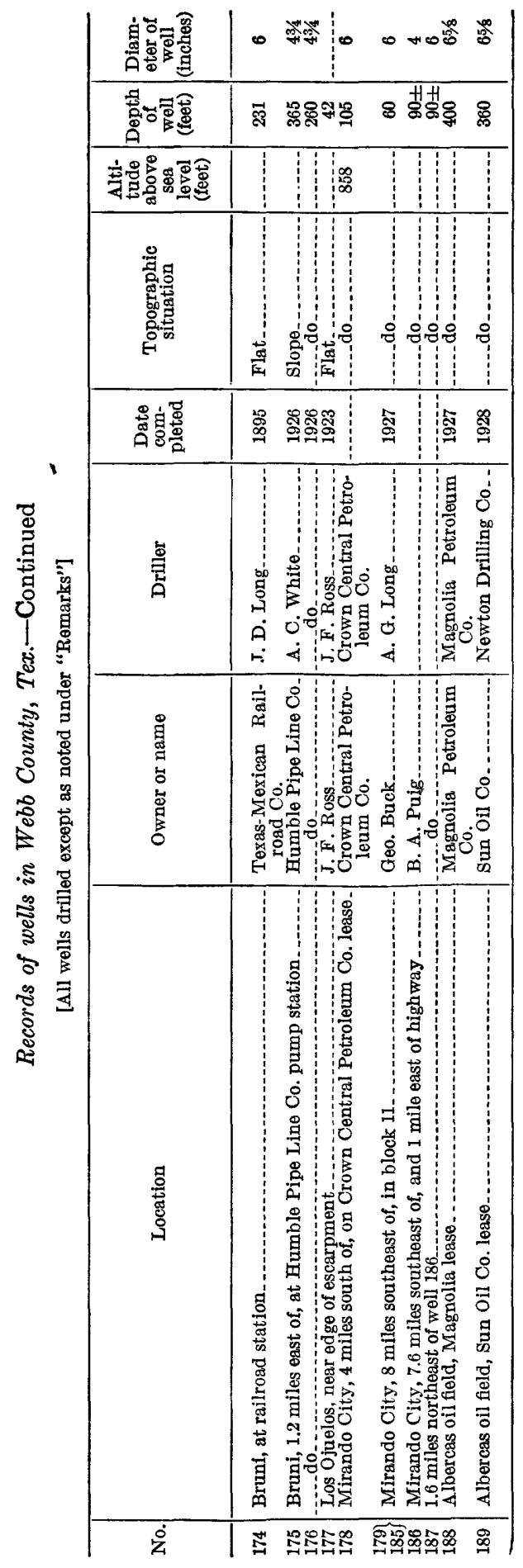


WELL TABLES

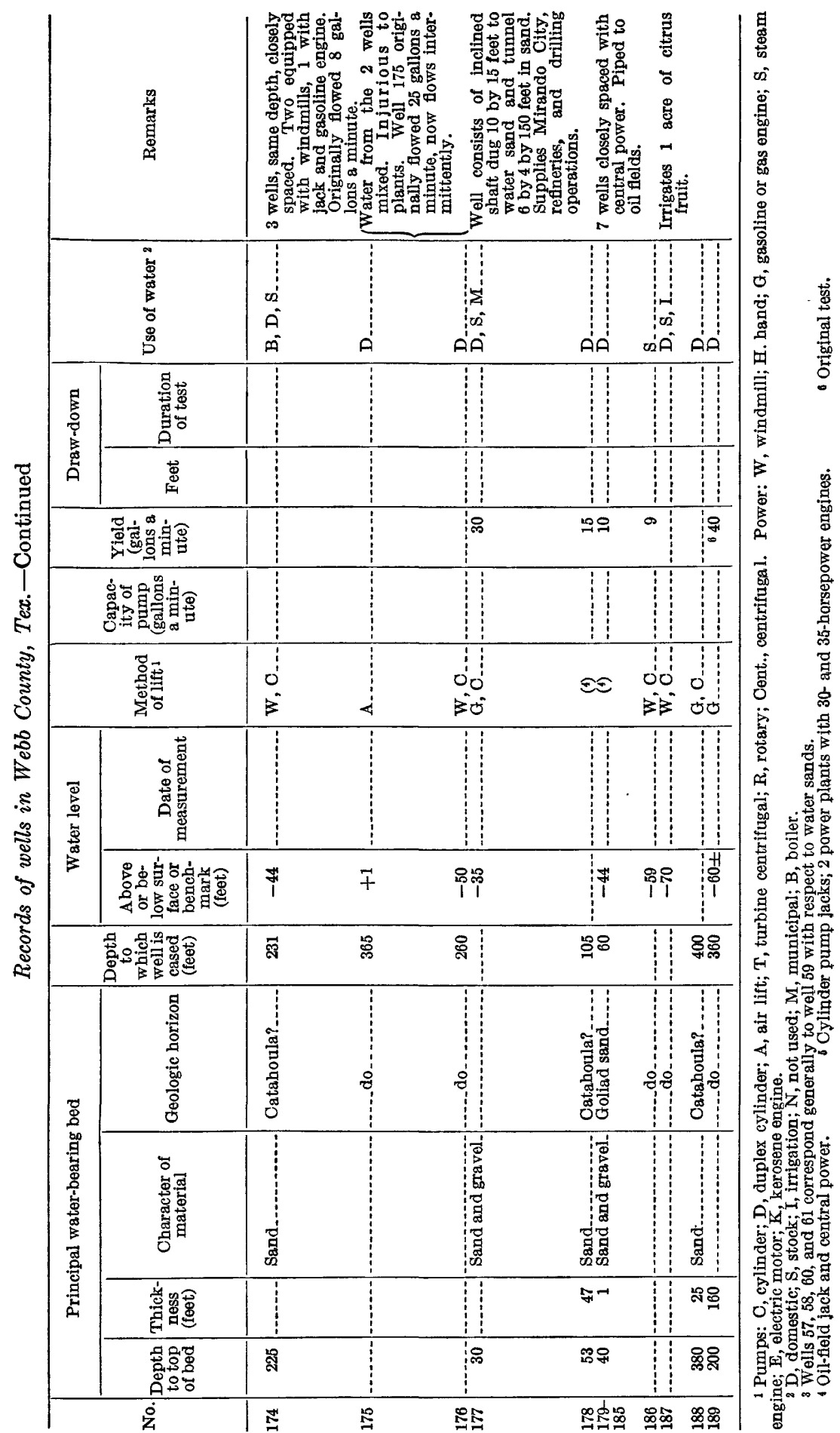




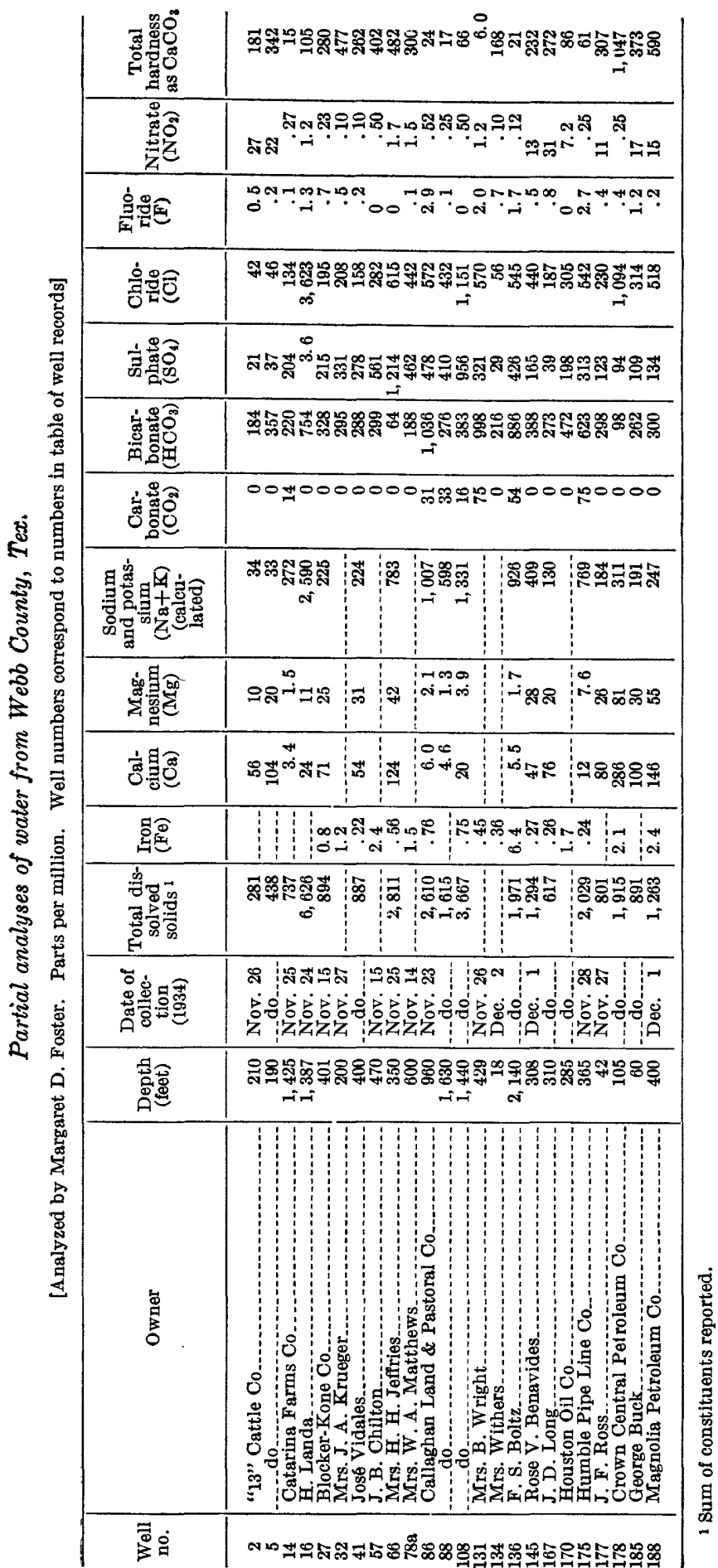




\section{N D EX}

\begin{tabular}{|c|}
\hline Page \\
\hline Abstract... \\
\hline Acknowledgments for aid. \\
\hline Agriculture in the area...... \\
\hline Aguilares Plain, features of \\
\hline $\begin{array}{l}\text { Alluvial deposits, character and distribution } \\
\text { of }\end{array}$ \\
\hline wells in..... \\
\hline Analyses of water.... \\
\hline Artesian water, formations yielding \\
\hline general principles of occurrence of \\
\hline $\begin{array}{l}\text { Bigford member of Mount Selman formation, } \\
\text { analyses of sandstone from } \ldots \ldots . .21-22\end{array}$ \\
\hline $\begin{array}{l}\text { areal extent of outcrop of } \ldots \ldots, \text { pl. } 1 \\
\text { character and thickness of } \ldots \ldots . .21-32\end{array}$ \\
\hline 21,23, pl. 1 \\
\hline $23-32,38$, pl. 8 \\
\hline water in \\
\hline wells in \\
\hline
\end{tabular}

See-also Post-Bigford beds.

Bordas escarpment, features of. 5, pls. 1, 3

Carrizo sand, analyses of.

areal extent of outcrop of.

16, pls. 1,6

character and thickness of -- $14,16-17$, pls. $1,5,6$ sections of .................. 17-18, 26-27, pl. 6 water in ............... 18-19, 32, 42, pls. 1,7 wells in.............. 18-19

Catahoula tufi, areal extent of outcrop of. 64-65, pl. 1 character and thickness of......... 14, 65-67 nomenclature and correlation of......... 64 relation of, to Bordas escarpment_..... 5 , pl. 1 sections of ............. 66-67 water in . ... . . . . . . . . . . . . . 1 quality of

wells in

Chusa tuff member of Catahoula tuff, absence

$$
\text { of. }
$$

Claiborne group, description of $16-62$, pls. $1,3,5-7,9,10,12$

Climate. acter of

7-9

Coal, occurrence and character of........ 21,

See also Lignite and specific beds.

Cook Mountain formation, areal extent of outcrop of .

character and thickness of . =......... 14,43-44 general features of ......... $42-43$, pl. 1 sections of ................ 33, 41, 44-53, pl. 10 water in analyses of . 55 occurrence of ............... 42, 53, pls. 1,11 quality of wells in....... $52-55$, pls. 1,11

Dentonio Plain, features of ............. 4, pl. 2 Drainage.
Eocene series, description of.

Page 14-62, pl. 1

Fant tuff member of Catahoula tuff, occur-

rence of........................ 64,65 Faults, occurrence and character of..... 10-12, pl. 1 Folds, occurrence and character of............ 11-12 Foster, Margaret D., analyses by........... 102 Frio clay, areal extent of outcrop of........ 63, pl. 1 character and thickness of ............. 14, 63

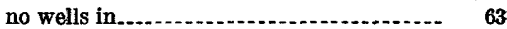
nomenclature and correlation of ......... 62 water in .......... 63 Frost data for the area

Gas. See Oil and gas.

Geologic formations, table of.

See also names of formations.

Geology, general features of ......... 9-12, 14, pl. 1

Goliad sand, areal extent of .......... 69-70, pl. 1 character and thickness of ........... 14, 70-71 relation of, to Bordas escarpment....... $5, \mathrm{pl} .1$ sections of......... 66-67, 70-71 water in ........... 71-72 wells in.......... 71-72

Gravel, quarrying of......................... 73, 74

Cround water, analyses of ............. 102 conclusions regarding supplies of general principles of occurrence of........-13-14 rock formations and their capacity for yielding... ................... 14-74, pl. 1 source and disposal of . . . . . . . 12 Gueydan formation, beds assigned to, by Bailey..... 60 . equivalent of Catahoula tuff............... 62, 64

Hebbronville Plain, features of.............. 5

Indio formation, areal extent of outcrop of. $14, \mathrm{pl} .1$ character and thickness of ............. 14-15 fossils in........... 15 sections of .......... $15-16, \mathrm{pl} .4$ water in . . wells in

Jackson formation, areal extent of outcrop of. 58, pl. 1 character and thickness of...... 14, 58-62, pl. 3 sections of .................. $39-62$, pl. 3 water in............................... 62

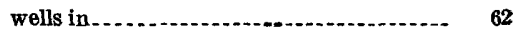

Lagarto formation, possible presence of _..... 10 Lignite,occurrence of.15, 21, 23, 24-25, 28, 29, 30, 31. pl.1 Location of area. 3

Maps, source of material for ..... 7

Mineral resources. 5 Miocene (?) series, description of .... 14, 64-69, pl. 1 


\begin{tabular}{|c|c|}
\hline Page & Page \\
\hline ount Selman forn & Recent series, description of........ \\
\hline $\begin{array}{l}\text { character and thickness of } \\
\text { sections of }\end{array}$ & $\begin{array}{c}\text { Rio Grande, breaks of, features of } \\
\text { tributaries of }\end{array}$ \\
\hline wells in & 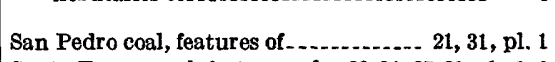 \\
\hline $\begin{array}{l}\text { Uueces Basin, features of } \\
\text { [ueces River, tributaries of }\end{array}$ & $\begin{array}{l}\text { ures of._. } 32-34,37-39, \text { pls. } 1,9 \\
\text { omerate member of Cat- } \\
\text {, occurrence of....... } 64,65\end{array}$ \\
\hline presence of & \\
\hline il ar & $n$ of \\
\hline 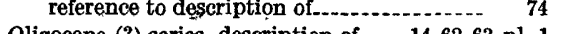 & Topography, general features of \\
\hline fon of...- 14,62-63, pl. 1 & Transportation in the area \\
\hline 14, 69-72, pl. 1 & occurrence of. 14, \\
\hline$f$ & Vegetation \\
\hline $\begin{array}{l}\text { Selman formation, } \\
\text { dstone from } \\
\text { of } \\
\text { of } 32, \text { pls. } 1,9 \\
14,32-41 \text {, pls. } 1,9 \\
\end{array}$ & $\begin{array}{l}\text { Water. See Ground water. } \\
\text { Wells, location of } \\
\text { logs of } \\
\text { records of }\end{array}$ \\
\hline (n) & Wilcox group, description of............ 14-16, pl. 1 \\
\hline 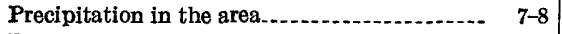 & \\
\hline & ind thickness of \\
\hline urpose of investigation & of \\
\hline & 58 \\
\hline
\end{tabular}

Quaternary system, description of wells in 
The use of the subjoined mailing label to return this report will be official business, and no postage stamps will be required

\section{UNITED STATES DEPARTMENT OF THE INTERIOR} GEOLOGICAL SURVEY

OFFICIAL BUSINESS

This label can be used only for returning official publications. The address must not be changed.
PENALTY FOR PRIVATE USE TO AVOII PAYMENT OF POSTAGE, $\$ 300$

\section{U. S. GEOLOGICAL SURVEY,}


